GEOHYDROLOGY AND NUMERICAL MODEL ANALYSIS OF GROUNDWATER FLOW IN THE GOOSE LAKE BASIN, OREGON AND CALIFORNIA

By David S. Morgan

U.S. GEOLOGICAL SURVEY

Water-Resources Investigations Report 87-4058

Prepared in Cooperation with

OREGON WATER RESOURCES DEPARTMENT

Portland, Oregon 


\section{UNITED STATES DEPARTMENT OF THE INTERIOR}

DONALD PAUL HODEL, Secretary

U.S. GEOLOGICAL SURVEY

Dallas L. Peck, Director

For additional information write to:

U.S. Geological Survey, WRD

847 N.E. 19th Ave., Suite 300

Portland, Oregon 97232
Copies of this report can

be purchased from:

U.S. Geological Survey

Books and Open-File Reports Section

Federal Center, Bldg. 810, Box 25425

Denver, Colorado 80225 


\section{CONTENTS}

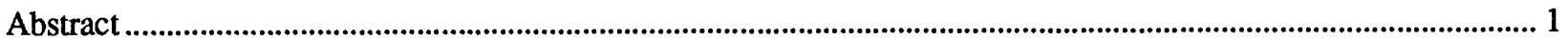

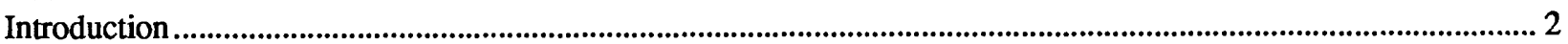

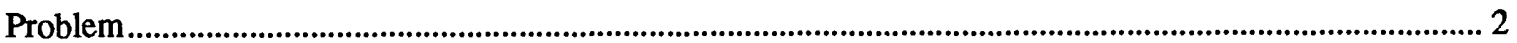

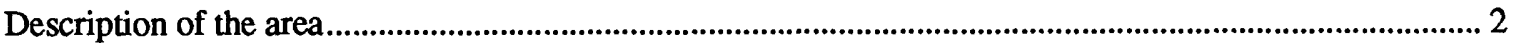

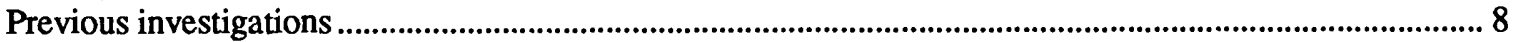

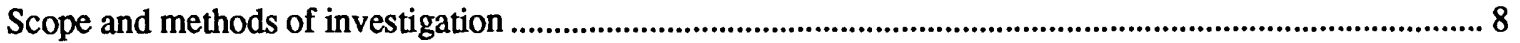

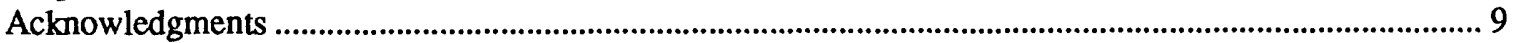

Geologic framework ................................................................................................................................................. 9

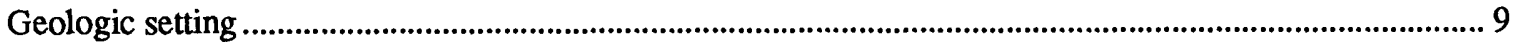

Lithologic units and their hydrologic character............................................................................................ 10

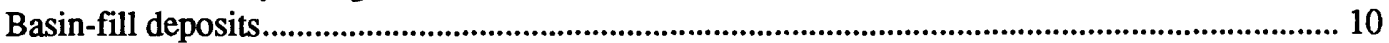

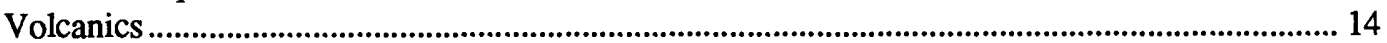

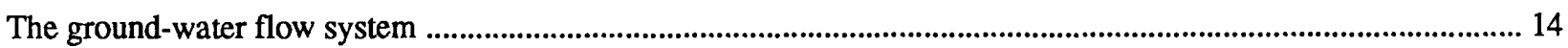

Conceptual model of the flow system ...................................................................................................... 14

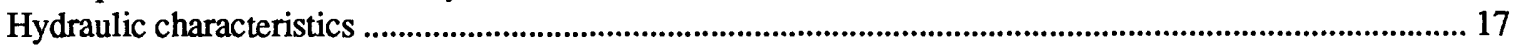

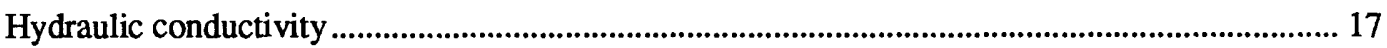

Horizontal hydraulic conductivity .............................................................................. 17

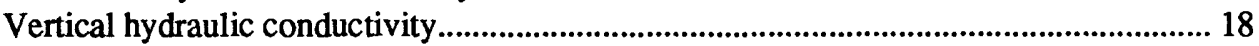

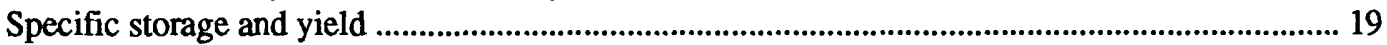

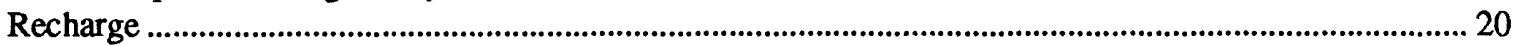

Deep percolation of precipitation and irrigation water ........................................................................ 20

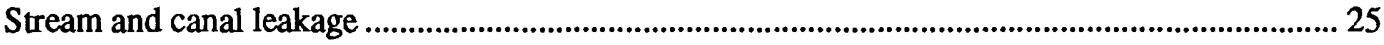

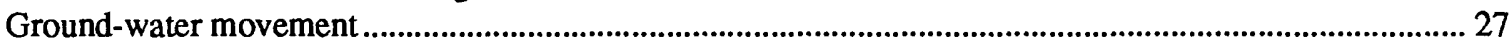

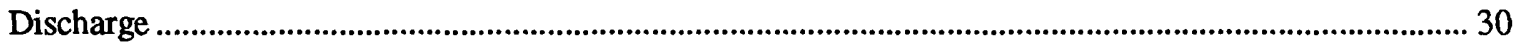

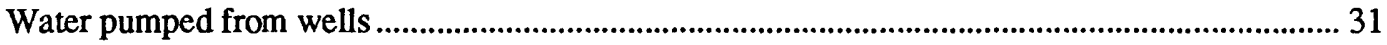

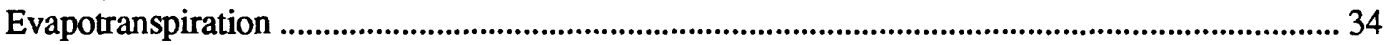

Seepage to Goose Lake and streams .................................................................................................... 35

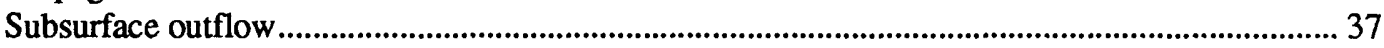

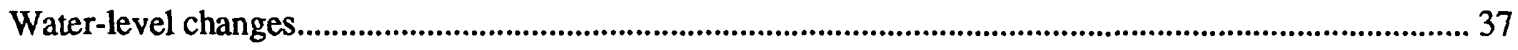

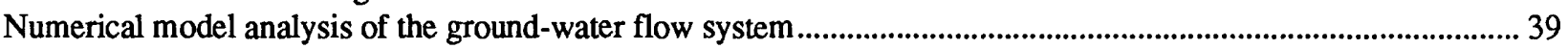

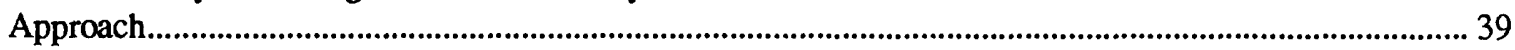

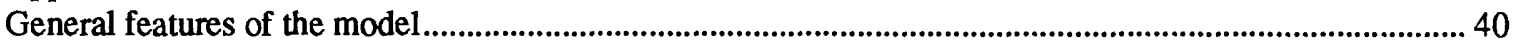

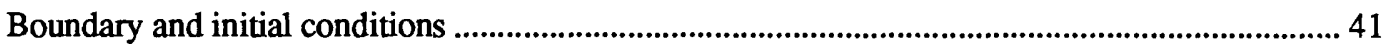

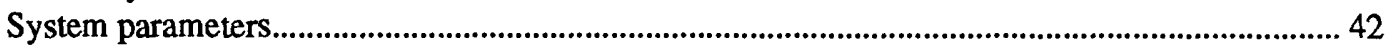

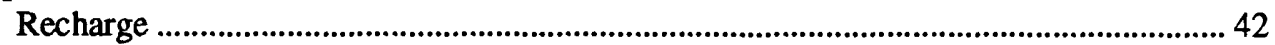

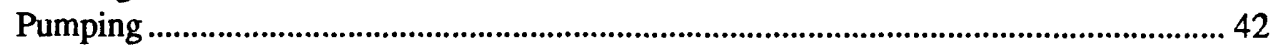

Transmissivity within model layers .............................................................................. 42

Vertical leakance between model layers................................................................................ 43

Lakebed conductance ........................................................................................................ 44

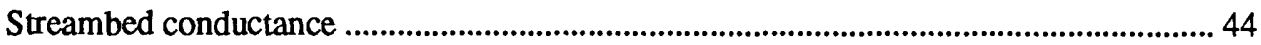

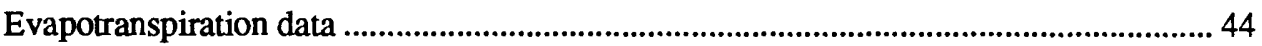

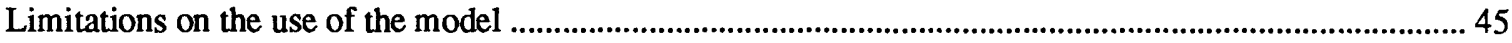

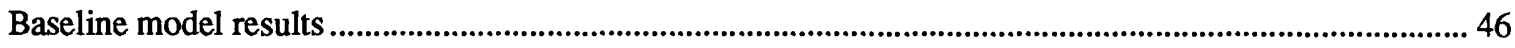

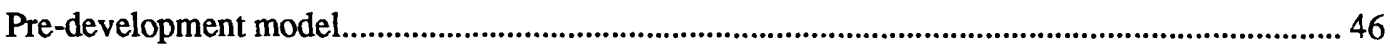

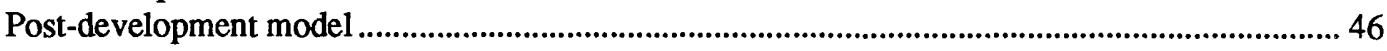

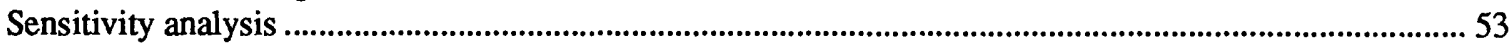

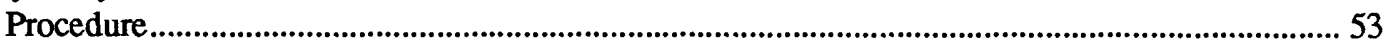

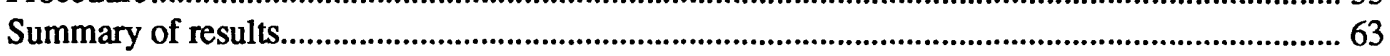

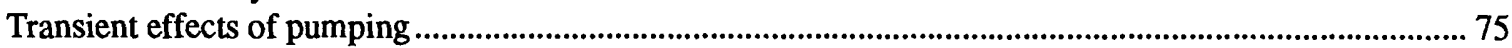

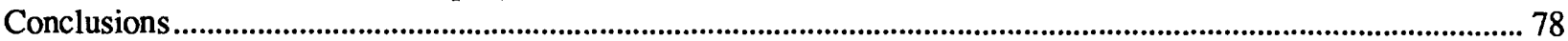




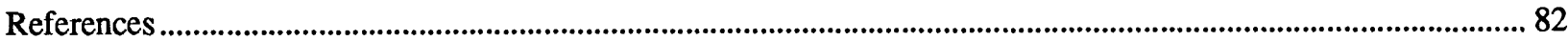

Appendix I--Technical aspects of the application of a deep percolation model for estimating ground-water recharge

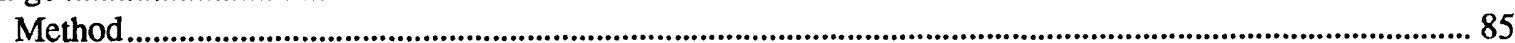

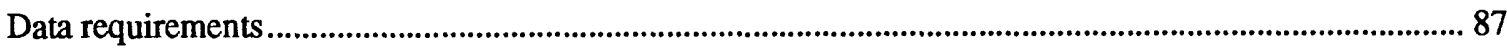

\section{ILLUSTRATIONS}

\section{[Plate is in pocket]}

Plate 1a. Generalized geologic map of the basin showing locations of monitoring wells, streammeasurement sites and gaging stations, and weather stations.

1b. Map showing (1) irrigated area by source of irrigation water, and (2) distribution and rate of ground-water withdrawals for irrigation, 1985.

Figure 1. Map showing location and general features of the study area ............................................................... 3

2. Graph showing cumulative number of wells constructed in the basin, by use, through 1985.

3. Graph showing permitted annual ground-water withdrawals, 1934-85

(Oregon only)

4. Map showing average annual precipitation in the Goose Lake basin, 1920-62 ......................................... 6

5a-5b. Graphs showing monthly climatic data for Lakeview, 1954-80:

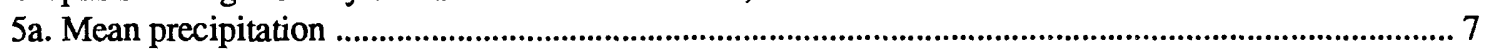

5b. Maximum, minimum, and mean temperature ................................................................................ 7

6. Map showing the cumulative thickness of coarse- grained basin-fill deposits in the depth

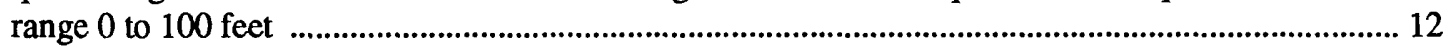

7. Map showing the cumulative thickness of coarse-grained basin-fill deposits in the depth

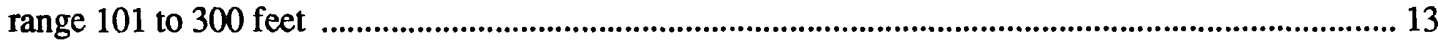

8. Map showing areas of the valley floor where basalts are penetrated by wells within a depth

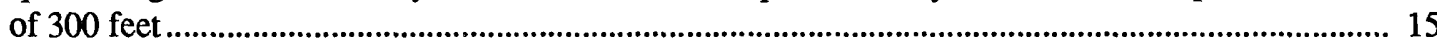

9. Diagrammatic section showing conceptual model of ground-water movement and major

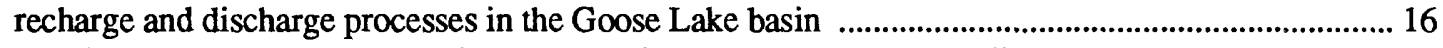

10. Graph showing the frequency distribution of estimated horizontal hydraulic conductivity for basalts and coarse- and fine-grained basin-fill deposits........................................... 19

11. Map showing the grid used to subdivide the basin for the recharge and ground-water model

12. Graph showing the mean-monthly hydrologic mass-balance within the root zone, 1954-1980 climatic conditions

13. Map showing mean annual recharge from deep percolation of precipitation and irrigation water for 1954-1980 climatic conditions and irrigation from surface-water sources only

14. Map showing the average altitude of the hydraulic head in wells less than 100 feet deep, 1948-60

15. Map showing the average altitude of the hydraulic head in wells more than 100 feet deep, 1948-60

16. Graph showing monthly electric power usage for irrigation (Oregon only), May to September 1985

17. Graph showing annual power consumption by irrigation pumps in Oregon, 1975-1986 
18. Hydrographs showing water-level changes at selected wells ............................................................... 38

19. Diagrammatic section of basin showing layering scheme used for ground-water model analysis

20a-20b. Maps showing simulated and observed hydraulic heads for pre-development base-line conditions:

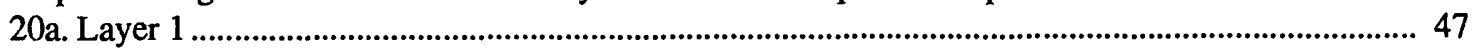

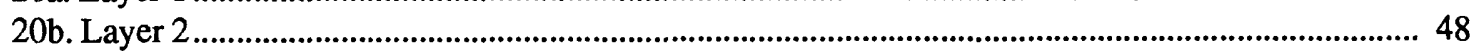

21. Graph showing frequency distribution of deviations between observed and computed hydraulic heads for pre-development base-line conditions

22a-22b. Maps showing simulated equilibrium water-level changes for post-development base-line conditions with pumping equal to 17,200 acre-feet/year (1985 rate):

22a. Layer 1

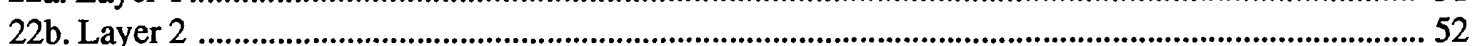

23. Graphs showing sensitivity of simulated heads and discharge to uncertainty in recharge estimates:

A. Recharge plotted against (1) mean deviation of computed from observed pre-development heads in layers 1 and 2, and (2) mean head in layers 1 and 2 ........................ 54

B. Recharge plotted against pre-development discharge by ET and seepage to streams and lakes

24. Graphs showing sensitivity of simulated drawdown and natural discharge rates to changes in pumping:

A. Pumping plotted against mean equilibrium drawdown at pumping locations in layers 1 and

B. Pumping plotted against natural discharge by ET and seepage to streams and lakes ......................... 55

25. Graphs showing sensitivity of simulated heads, drawdown, and discharge to uncertainty in estimates of basin-fill transmissivity:

A. Transmissivity plotted against pre-development (1) mean deviation of computed from observed heads in layers 1 and 2, and (2) mean head in layers 1 and 2

B. Transmissivity plotted against pre-development discharge by ET and .......................................... 56

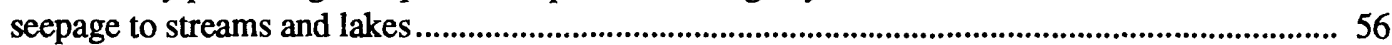

C. Transmissivity plotted against post- development drawdown at pumping locations in layers 1 and 2

D. Transmissivity plotted against post-development discharge by ET and seepage to streams and lakes

26. Graphs showing sensitivity of simulated heads, drawdown, and discharge to uncertainty in estimates of volcanic transmissivity:

A. Transmissivity plotted against (1) mean deviation of computed from observed pre-development heads in layers 1 and 2, and (2) mean head in layers 1 and 2 .......................... 57

B. Transmissivity plotted against pre-development discharge by ET and seepage to streams and lakes

C. Transmissivity plotted against mean equilibrium drawdown at pumping locations in layers 1 and 2

D. Transmissivity plotted against post-development discharge by ET and seepage to streams and lakes.

27. Graphs showing sensitivity of simulated heads, drawdown, and discharge to uncertainty in estimates of basin-fill vertical leakance:

A. Vertical leakance plotted against (1) mean deviation of computed from observed pre-development heads in layers 1 and 2, and (2) mean head in layers 1 and 2

B. Vertical leakance plotted against pre-development discharge by ET and seepage to streams and lakes.

C. Vertical leakance plotted against mean equilibrium drawdown at pumping locations in layers 1 and 2 
D. Vertical leakance plotted against post-development discharge by ET and seepage to streams and lakes

28. Graphs showing sensitivity of simulated heads, drawdown, and discharge to uncertainty in estimates of volcanic vertical leakance:

A. Vertical leakance plotted against (1) mean deviation of computed from observed pre-development heads in layers 1 and 2 , and (2) mean head in layers 1 and 2

B. Vertical leakance plotted against pre-development discharge by ET and seepage to streams and lakes

C. Vertical leakance plotted against mean equilibrium drawdown at pumping locations in layers 1 and 2

D. Vertical leakance plotted against post-development discharge by ET and seepage to streams and lakes.

29. Graphs showing sensitivity of simulated heads, drawdown, and discharge to uncertainty in estimates of lakebed conductance:

A. Lakebed conductance plotted against (1) mean deviation of computed from observed pre-development heads in layers 1 and 2, and (2) mean head in layers 1 and 2

B. Lakebed conductance plotted against pre-development discharge by ET and seepage to streams and lakes.

C. Lakebed conductance plotted against mean equilibrium drawdown at pumping locations in layers 1 and 2

D. Lakebed conductance plotted against post-development discharge by ET and seepage to streams and lakes.

30. Graphs showing sensitivity of simulated heads, drawdown, and

discharge to uncertainty in estimate of streambed conductance:

A. Streambed conductance plotted against (1) mean deviation of computed from observed pre-development heads in layers 1 and 2, and (2) mean head in layers 1 and 2 .

B. Streambed conductance plotted against pre-development discharge by ET and seepage to streams and lakes.

C. Streambed conductance plotted against mean equilibrium drawdown at pumping locations in layers 1 and 2

D. Streambed conductance plotted against post-development discharge by ET and seepage to streams and lakes.

31. Graphs showing model sensitivity to uncertainty in selected parameters for pre-development and post-development models

32. Map showing simulated plotted against observed pre-development heads in layer 1 when volcanic vertical leakance is equal to base-line values times a factor of 1 .

33. Map showing simulated plotted against observed pre-development heads in layer 1

when recharge is equal to 77 percent of base-line recharge $(170,000$ acre-feet/year

34a-34c. Maps showing simulated equilibrium drawdown in layer 2 for various pumping rates:

34a. 34,400 acre-feet/year

34b. 68,800 acre-feet/year .

34 c. 138,000 acre-feet/year

35. Map showing simulated equilibrium drawdown in layer 2 when basin-fill transmissivity is equal to base-line values times a factor of 0.3

36. Map showing simulated equilibrium drawdown in layer 2 when volcanic transmissivity is equal to base-line values times a factor of 0.1

37. Map showing simulated equilibrium drawdown in layer 2 when basin-fill vertical leakance is equal to base-line values times a factor of 0.1

38. Map showing simulated equilibrium drawdown in layer 2 when volcanic vertical leakance is equal to base-line values times a factor of 0.1 
39. Map showing simulated equilibrium drawdown in layer 2 when pumpage is eight times 1985 rates and specified-head boundary conditions are used near Davis Ceek......................... 75

40. Map showing simulated equilibrium drawdown in layer 2 using minimum (worst-case) values of model parameters

41a-41b. Graphs showing results of 300-year transient simulation of pumping equal to 68,800 acre-feet/year:

41a. Hydrograph of mean computed drawdown in layers 1 and 2 .

$41 \mathrm{~b}$. Computed rates of natural discharge and storage depletion with time

\section{TABLES}

Table 1. Lithologic classifications used to standardize geologic descriptions on drillers' report

2. Horizontal hydraulic conductivity estimates for principal lithologic units found in

Goose Lake basin

3. Estimated annual basin-wide water-budget for the soil/root zone

4. Seepage data for selected stream reaches in Goose Lake basin, August 11-15, 1986

5. Permitted ground-water withdrawals in the Oregon portion of the Goose Lake basin, 1986

6. Sensitivity of 1985 Goose Lake basin pumpage estimates to uncertainties in pumping lift, discharge pressure head, and pumping efficiency factor.

7. Summary of lake-budget estimates for Goose Lake by previous studies and this study ........................... 36

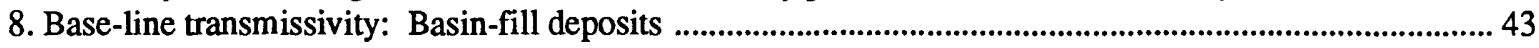

9. Base-line vertical leakance: Basin-fill deposits ............................................................................................... 43

10. Pre-development ground-water budget for the Goose Lake basin, computed using the base-line model parameters.

11. Post-development ground-water budget for the Goose Lake basin, computed using the base-line model parameters

12. Estimates of minimum system parameter values used for a "worst-case" hypothetical simulation 
For use of those readers who may prefer to use metric (International System) units rather than inch-pound units, the conversion factors for the terms used in this report are listed below:

Length

inch (in.)

foot (ft)

mile (mi)

square foot ( $\left.\mathrm{ft}^{2}\right)$

square mile $\left(\mathrm{mi}^{2}\right)$

acre-foot (acre-ft)

acre-feet per year, (acre-ft/yr)

cubic foot per second $\left(\mathrm{ft}^{3} / \mathrm{s}\right)$
25.4

0.3048

1.609

$\underline{\text { Area }}$

0.0929

2.590

square meter $\left(\mathrm{m}^{2}\right)$

square kilometer $\left(\mathrm{km}^{2}\right)$

Volume

1,233 .

cubic meter $\left(\mathrm{m}^{3}\right)$

Flow

0.000039

0.02832 cubic meter per second, $\left(\mathrm{m}^{3} / \mathrm{s}\right)$

cubic meter per second $\left(\mathrm{m}^{3} / \mathrm{s}\right)$

Sea level: In this report "sea level" refers to the National Geodetic Vertical Datum of 1929 (NGVD of 1929), a geodetic datum derived from a general adjustment of the first-order level nets of both the United States and Canada, formerly called "Sea Level Datum of 1929." 


\section{Well-numbering System}

The well-numbering system used in this report is based on the rectangular system for subdivision of public land. Each "number" (actually number-letter designation) indicates the location of the well with respect to township, range, and section. Number 39S/20E-16bab indicates a well in T. 39 S., R. 20 E., sec. 16. Townships shown in the Oregon part of the basin are numbered south and east of the Willamette Baseline and Meridian (for example, 39S/20E). Townships in the California part of the basin are numbered north and east of the Mount Diablo Baseline and Meridian (for example, 48N/14E). The letters show the location within the section; the first letter (b) identifies the quarter section (160 acres); the second letter (a), the quarter-quarter section (40 acres); and the third letter (b) the quarter-quarter-quarter section (10 acres). Well 16bab is in the NW quarter of the NE quarter of the NW quarter of section 16, township 2 south, range 2 east (see figure below). Where more than one well is located within a 10 -acre tract, a serial number is added following the letter sequence to distinguish them. Springs are numbered in the same manner except that the letter "s" is added following the final letter.

On the well-location map (pl. 1-a), each well symbol is identified only by the section number and the final letter sequence, inasmuch as the township and range numbers are shown on the base map. In the text of the report the entire designations are used.

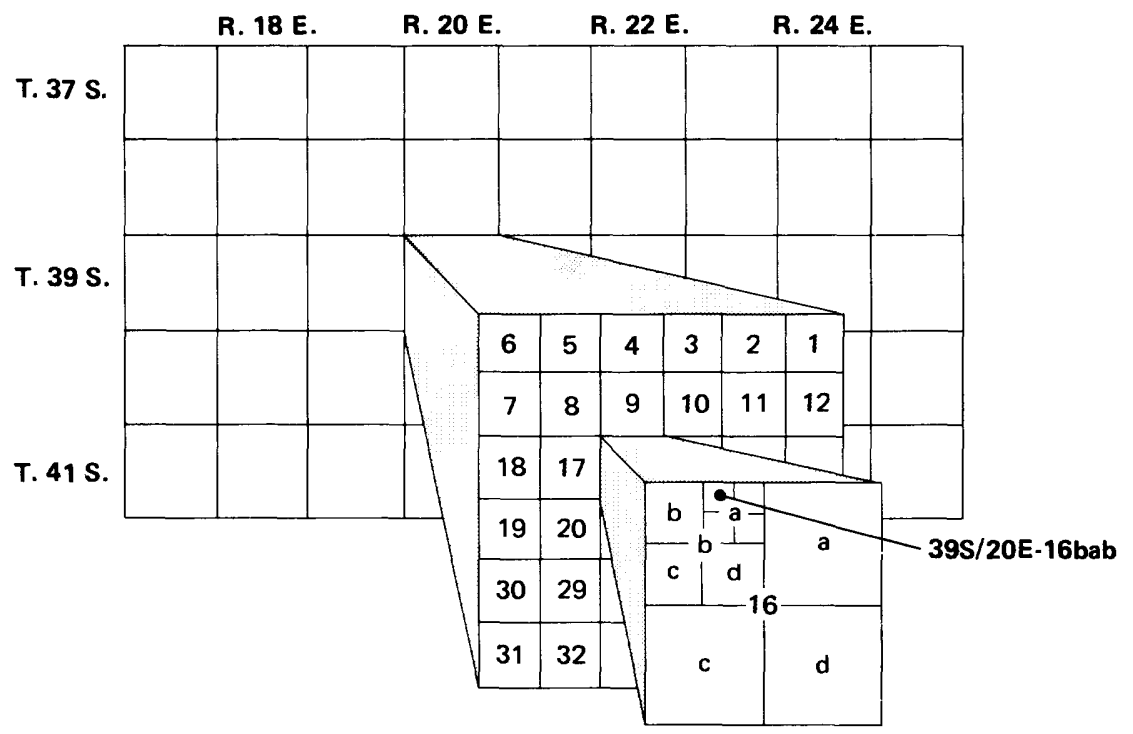




\title{
GEOHYDROLOGY AND NUMERICAL MODEL ANALYSIS OF GROUND-WATER FLOW IN THE GOOSE LAKE BASIN, OREGON AND CALIFORNIA
}

\author{
By David S. Morgan
}

\begin{abstract}
The Goose Lake basin in south-central Oregon and northeastern California experienced a period of rapid growth in ground-water withdrawals for irrigation between 1972 and 1981 . Measured water-level declines of as much as 13 feet occurred during this period, with maximum rates of decline of up to 3 feet per year. Ground-water withdrawals in the basin have decreased since 1981 to an estimated 17,200 acre-feet per year in 1985. Approximately 12,500 acre-feet per year were withdrawn on the Oregon side of the basin, compared with currently (1986) permitted withdrawals of 63,000 acre-feet per year.

The fault-bounded structural basin that forms the valley contains up to 5,000 feet of mostlyunconsolidated basin-fill deposits of Pliocene, Pleistocene, and Holocene age. Lenses of sand and gravel comprise the most important aquifers within the heterogeneous alluvial, fluvial, and lacustrine sediments. The thick sequence of Tertiary volcanic rocks that underlie most of the upland areas surrounding the basin are mostly composed of lower-permeability tuffs and tuffaceous sediments; however, fractured and (or) scoriacious basalt flows locally have high permeability. Mean estimated horizontal hydraulic conductivities for mostly fine-grained basin-fill deposits, mostly coarse-grained basin-fill deposits, and basalts are 7, 20, and 30 feet per day, respectively.
\end{abstract}

Potential recharge to the basin from deep percolation of precipitation and irrigation was estimated by using energy- and moisture-balance methods. Approximately 90 percent of the estimated ground-water recharge $(220,000$ acre-feet per year) occurs in the upland areas of the basin. An estimated 130,000 acre-feet per year of ground water is discharged by seepage to Goose Lake. The remaining natural discharge is primarily by evapotranspiration supplied from the shallow water table underlying much of the valley floor, although some discharge occurs by seepage to streams.

A numerical simulation model of the ground-water flow system was constructed and used as an analytical tool to (1) test the conceptual model of the system, (2) evaluate the adequacy of available data, (3) estimate worst-case hydrologic impacts of ground-water development, and (4) prioritize future datacollection activities.

Comparison of simulated pre-development ground-water conditions with observed conditions supported the conceptual model of the flow system and increased confidence levels in estimates of recharge, discharge, and most aquifer properties. Sensitivity analysis revealed that uncertainty in estimates of basin-fill transmissivity and vertical leakance caused the greatest variation in simulated water-level declines when compared to those caused by uncertainties in other parameters. For pumping rates totaling 70,000 acre-feet per year, slightly more than the currently (1985) permitted withdrawals of 63,000 acre-feet per year, simulated equilibrium water-level declines in the 100- to 800-foot depth interval averaged 36 feet and had a maximum of 100 feet when baseline values of system parameters were assumed. Reducing system parameters to minimum values within estimated confidence intervals and utilizing the same rate of pumping withdrawals, resulted in simulated equilibrium water-level declines that averaged 113 feet and had a maximum of 250 feet. A 300-year transient simulation, using baseline system parameters and estimated storage coefficients, indicated that rates of water- level decline would be greatly attenuated within 20 years and re-equilibration would be essentially complete within 100 years. 


\section{INTRODUCTION}

This study of the Goose Lake basin (fig. 1) was undertaken in cooperation with the Oregon Water Resources Department (OWRD) as a part of a Statewide program designed to systematically assess Oregon's ground-water resources. The overall objective of this program is to characterize the geohydrology of each of the State's ground-water systems in order to provide information to effectively manage the resource.

\section{Problem}

From the early 1970's until 1981, ground-water development in the Goose Lake basin underwent rapid growth. The number of new wells constructed (fig. 2) and total State-permitted ground-water withdrawals for irrigation (fig. 3) reflect the increase in ground-water development that occurred during this period.

A strong agricultural economy spurred much of the development by providing incentives to expand irrigated acreage and modernize irrigation methods (from gravity to sprinkler systems). The drought of 197677 also encouraged farmers to develop ground water as a supplemental source to less reliable surface-water supplies used in the past.

A preliminary assessment of the basin by OWRD staff (R. B. Almy, Oregon Department of Water Resources, written commun., 1981) concluded that, based on rates of water-level decline and increases in withdrawals, further and more detailed study of the basin was warranted. Between 1975 and 1982, waterlevel declines in some OWRD observation wells ranged from 0.5 to 3 feet per year, while permitted groundwater withdrawals increased at an average rate of 4,000 acre-feet per year (acre-ft/yr). Similar water-level declines and increases in withdrawals occurred near Davis Creek on the California side of the basin during this period. This prompted a 1982 assessment of ground-water conditions by the California Department of Water Resources (California Department of Water Resources, 1982).

At the time of OWRD's assessment it was felt that too little information on the actual rates of ground-water use, recharge, and the geohydrology of the aquifer system was available to allow proper management of the resource. If the rates of water-level decline and ground-water withdrawal that existed prior to 1981 had continued, issuance of new permits for ground-water use potentially could have been halted in order to determine if the Goose Lake basin should be designated as a "critical ground-water area." Such a designation would allow the State of Oregon to limit the use of ground-water resources in the area. However, overdraft of the ground-water resource became a less urgent issue after 1982, when a downturn in the agricultural economy, combined with rising costs of electrical power (and thus pumping), resulted in a widespread reversion to dryland farming and low-water-use crops.

Adverse agricultural market conditions halted the growth of ground-water development in the basin; these trends could conceivably reverse in the future to spur growth again. In recognition of this potential and the need to build an understanding of the basin in order to properly manage future ground-water development, OWRD entered into a joint program of study with the U.S. Geological Survey. The first of a proposed series of ground-water basin assessments, this 1-year study was started in 1986 with the goals of characterizing the nature, extent, and properties of water-bearing rocks within the basin and describing and quantifying the components of recharge to, and discharge from, the basin. Additionally, this study was designed to evaluate the adequacy of available and readily collectable information to quantitatively describe the geohydrology of the basin. If this information was found to be inadequate, the study would also identify the data needed to better describe, understand, and manage the ground-water resource.

\section{Description of the Area}

The Goose Lake basin is located in extreme south-central Oregon and northeastern California (fig. 1). The basin and the lake itself span the State border, with about two-thirds of the 1,100-square-mile basin in Lake County, Oregon. Most of the remainder of the basin is in Modoc County, California; a small part of the western basin, however, is in Klamath County, Oregon. At its present altitude of approximately 4,700 


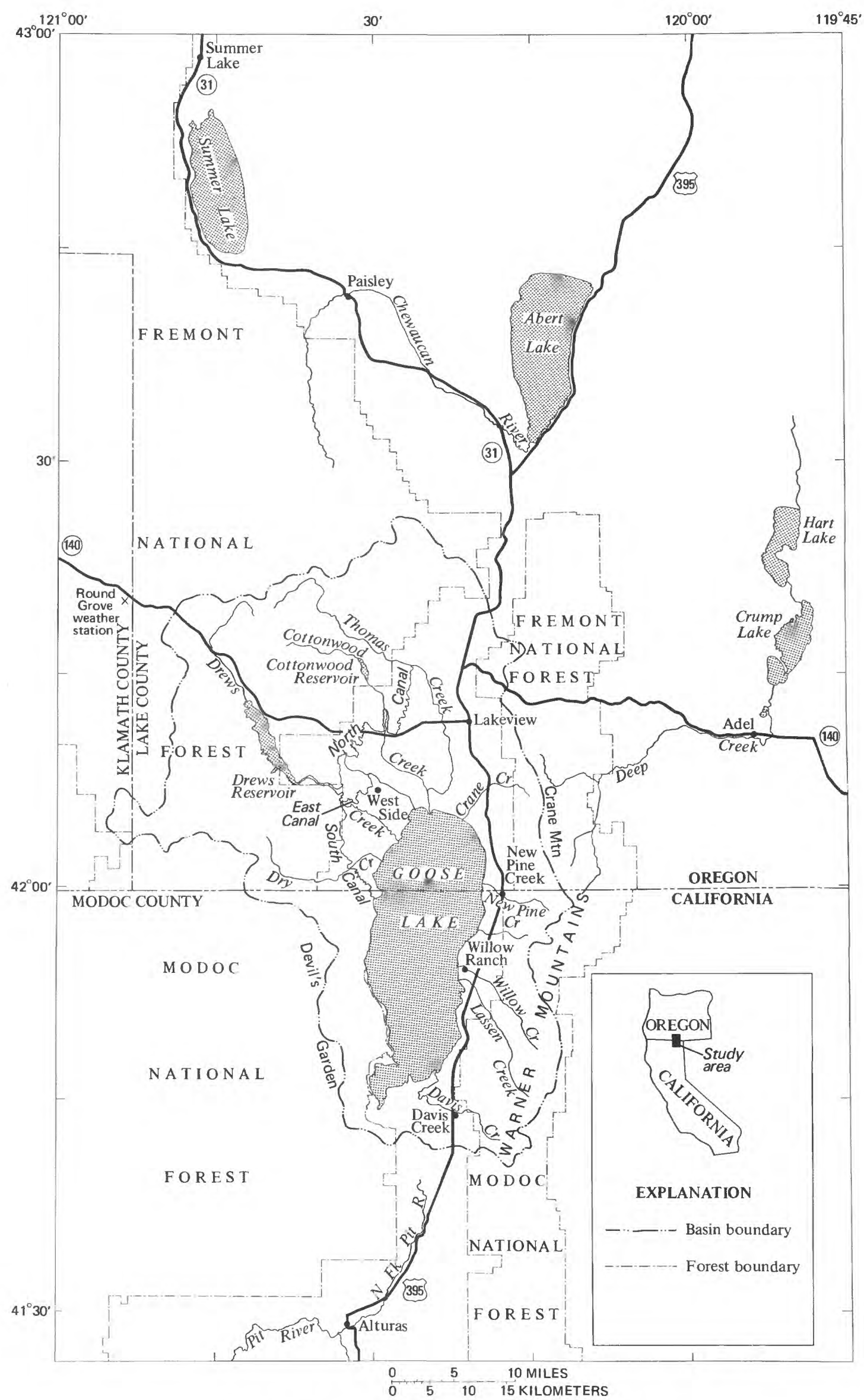

Figure 1.--Location and general features of the study area. 


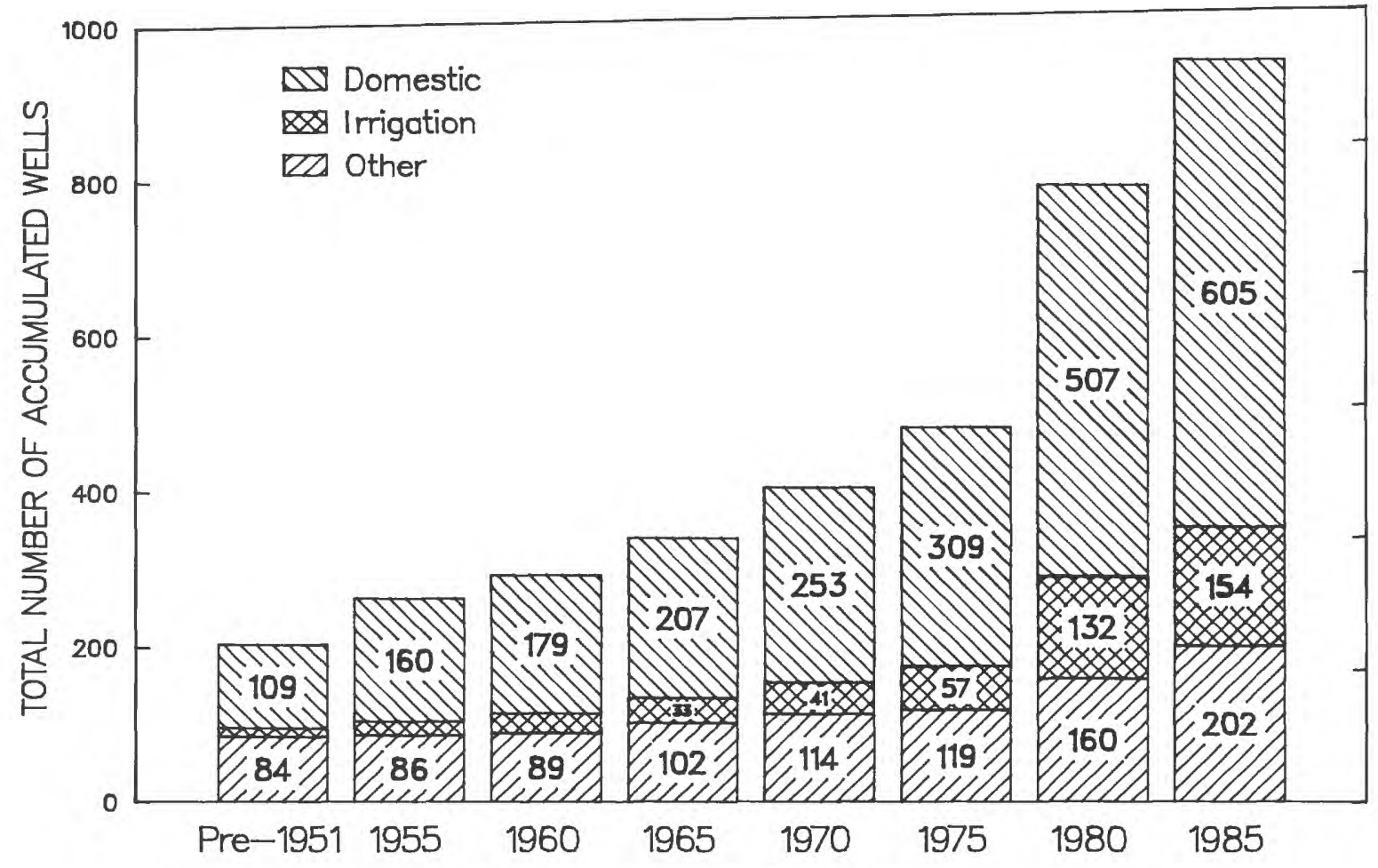

Figure 2.--Cumulative number of wells constructed in the basin, by use, through 1985 .

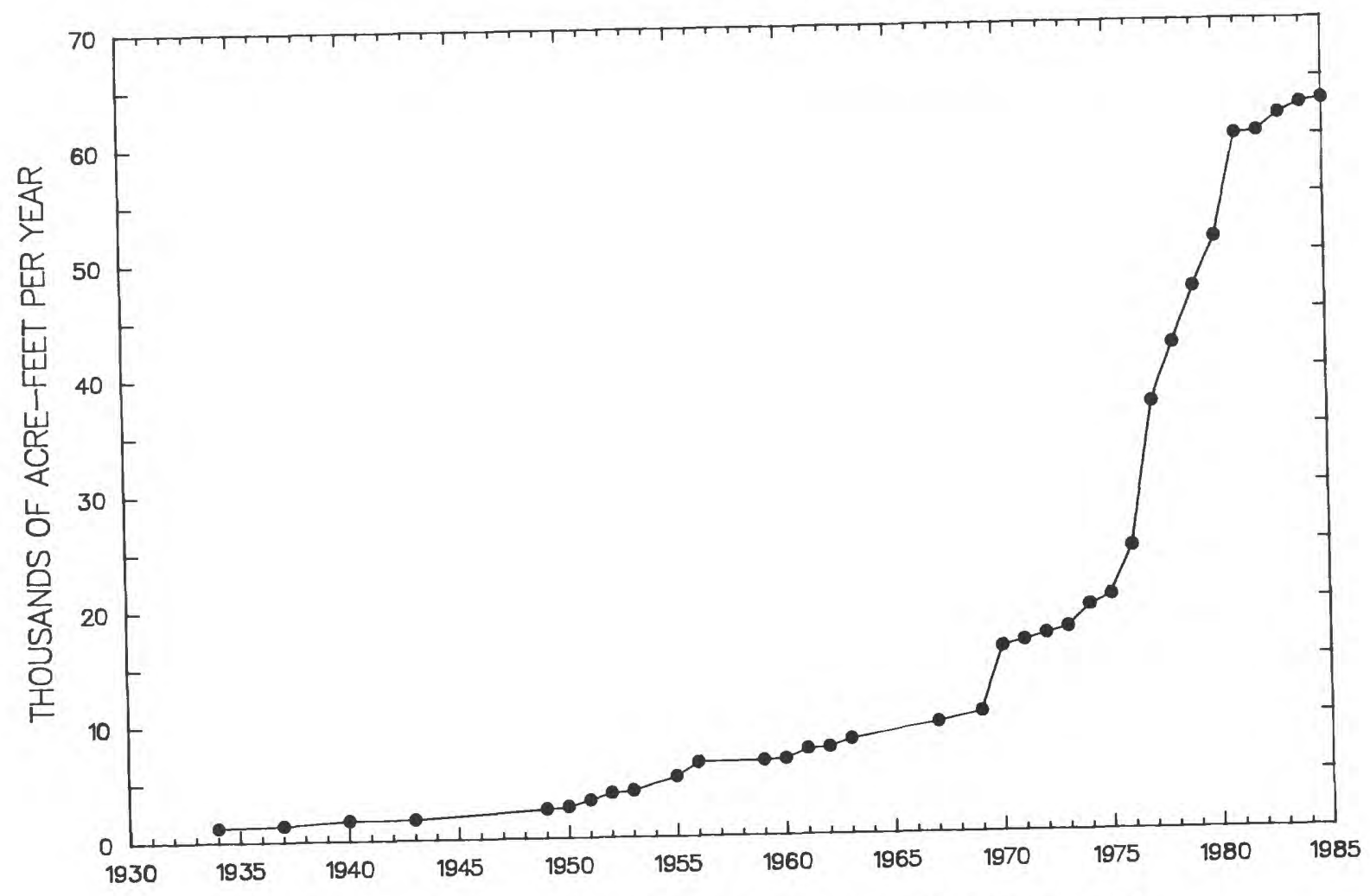

Figure 3.--Permitted annual ground-water withdrawals, 1934-85 (Oregon only). 
feet above sea level, Goose Lake occupies 144 square miles in the southern end of the basin. The basin is slightly elongated about its north-south axis and extends 53 miles in this direction, with a maximum width of 36 miles.

Goose Lake basin lies in the extreme northwestern part of the Basin and Range Province, near its transitional zone with the High Cascade Range. The valley floor occupies about 400 square miles and makes up a larger percentage of the Oregon side of the basin than of the California side. These lowlands generally lie below an altitude of 5,000 feet and slope gently upward, away from the lake. On the east side of the basin, the Warner Mountains rise steeply from the valley lowlands to altitudes of up to 8,454 feet at Crane Mountain. The transition from valley lowlands to uplands is more gradual on the north and west sides, where old lake terraces--up to 5 miles wide--rise 200-300 feet above the valley before giving way to mountainous uplands of the Fremont National Forest, which reach altitudes of over 7,000 feet. 'Southwest of the basin, a broad, flat volcanic ridge lies 800-1,000 feet above Goose Lake and extends nearly to the shore of the lake.

The mean annual precipitation at the Lakeview weather station (altitude 4,780 feet) is 16.1 inches (water years 1954-80). The minimum precipitation during this period was 9 inches and the maximum was 24 inches. Four miles northwest of the basin, at the Round Grove Ranger Station (altitude 4,890 feet), precipitation averaged 18.3 inches per year for the same period, with a range of 13 to 24 inches. Weather station locations are shown on plate 1a. Data from about 20 short-term precipitation gages in and adjacent to the basin at altitudes between 4,325 and 6,775 feet were used to construct the lines of equal precipitation shown in figure 4 (Daum, 1966). This map indicates a strong correlation between altitude and precipitation within the basin. Average annual precipitation shown in figure 4 ranges from 12 inches per year on the surface of Goose Lake to 32 inches per year at the crest of the Warner Mountains. Most precipitation occurs during the months of December and January, and the least occurs during July and August; about 70 percent of precipitation in the basin falls as snow (U.S. Department of Agriculture, 1978). The seasonal distribution of precipitation is shown in figure 5-a. Mean annual temperature at Lakeview (water years 1946-1975) is 46 F. Minimum average monthly temperature occurs in January ( $29 \mathrm{oF})$, and the maximum average occurs in July $(67 \mathrm{oF})$, as shown in figure 5-b. The growing season generally lasts 120 days in the lower valley and 80 days at higher elevations.

All surface drainage in the basin is to Goose Lake. The lake has historically spilled over the low topographic divide at the southern end of the valley to the North Fork Pit River. However, since the diversion of major streams for irrigation, overflow has not occurred and is not likely to occur. Perennial streams are typical of the forested watersheds of the Fremont National Forest. Drews, Thomas, and Cottonwood Creeks are the major drainages for this area. Intermittent streams characterize the flanks of the Warner Mountains, where streams commonly are lost to infiltration of the permeable alluvial-fan deposits that they traverse after leaving the canyons. Willow, Lassen, Davis, and New Pine Creeks are the major streams of the California part of the basin (fig. 1).

Most streams in the basin have their peak discharge in April or May, when they are fed by snowmelt. A number of reservoirs store this runoff for use during the irrigation season. The largest of the reservoirs are Drews Reservoir (capacity 63,568 acre-ft) and Cottonwood Reservoir (capacity 8,740 acre-ft).

The basin was first settled in the late 1800 's, and the local economy has always been oriented toward agriculture. Livestock ranching is the predominant type of agriculture in the basin, with a large percentage of cropland used to grow hay and feed grains, which are used locally. Timber, harvested from the Fremont National Forest, provides another source of income and jobs for the local economy. Lakeview is the largest community in the basin, with a population of 2,770 as of 1980 . Smaller communities have been developed near West Side, Oregon, and Davis Creek and New Pine Creek, California, and the population of the basin in 1970 was 4,830 . 


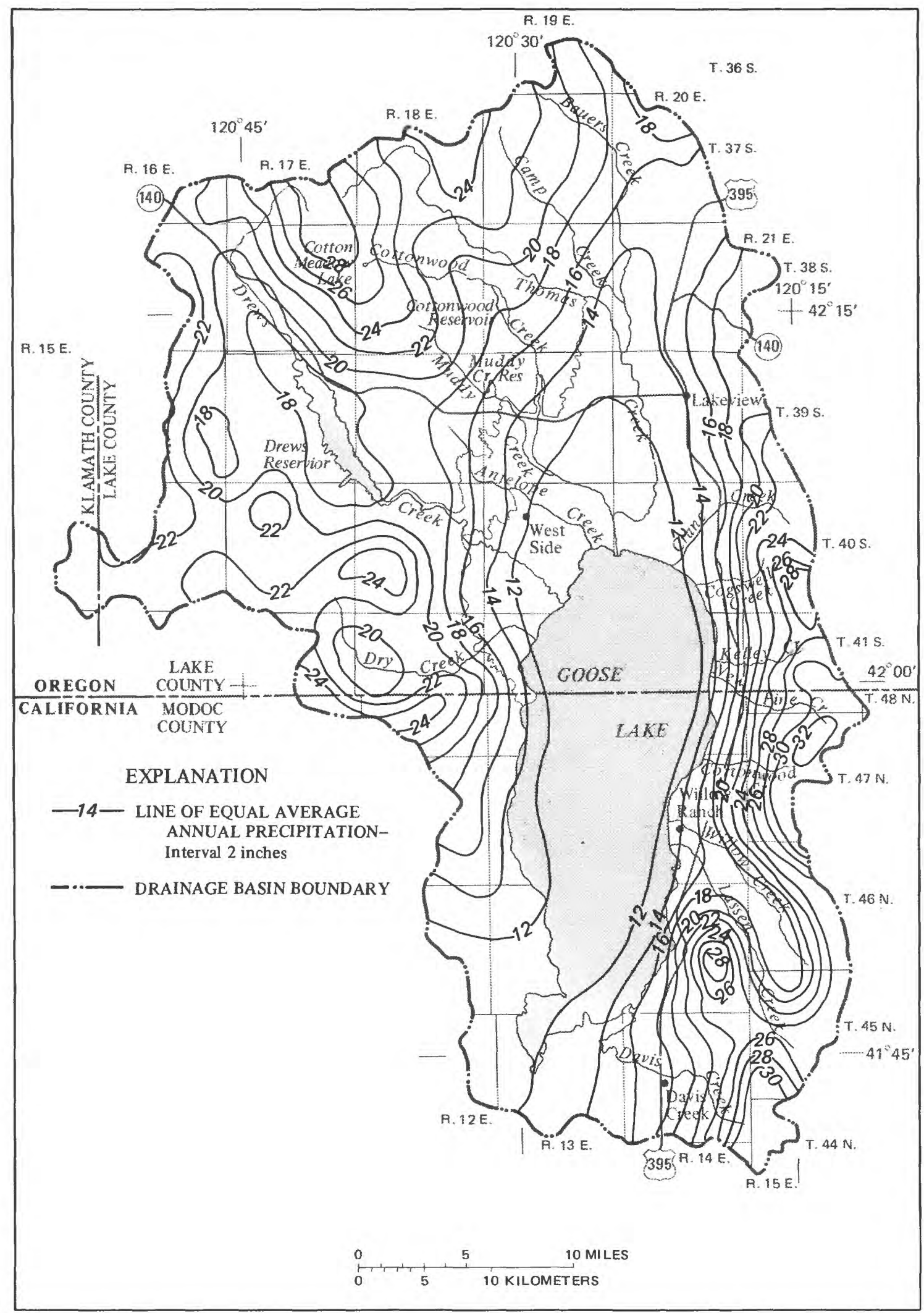

Figure 4.--Average annual precipitation in the Goose Lake basin, 1920-62. 


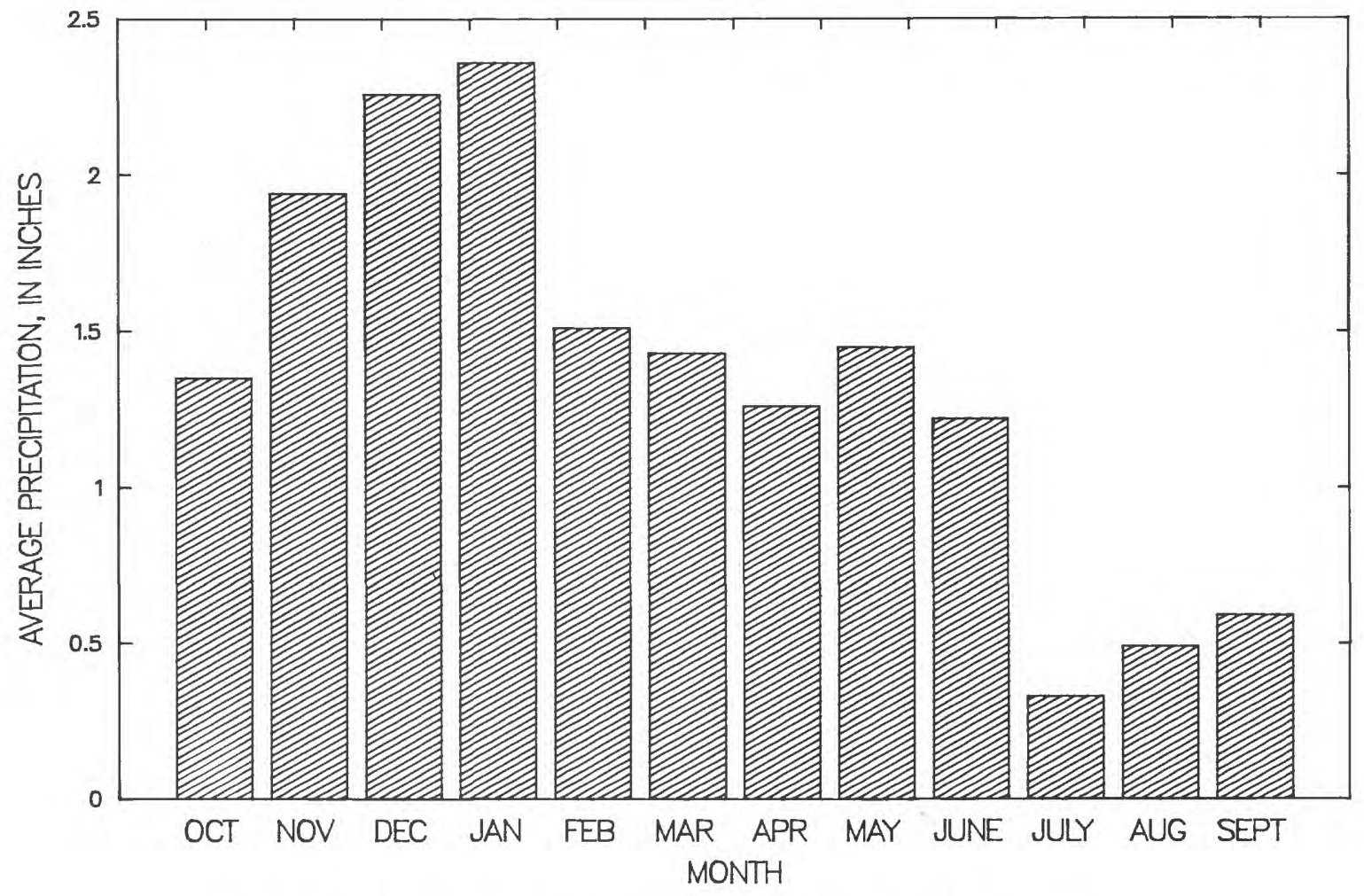

Figure 5a.--Monthly climatic data for Lakeview, 1954-80: Mean precipitation.

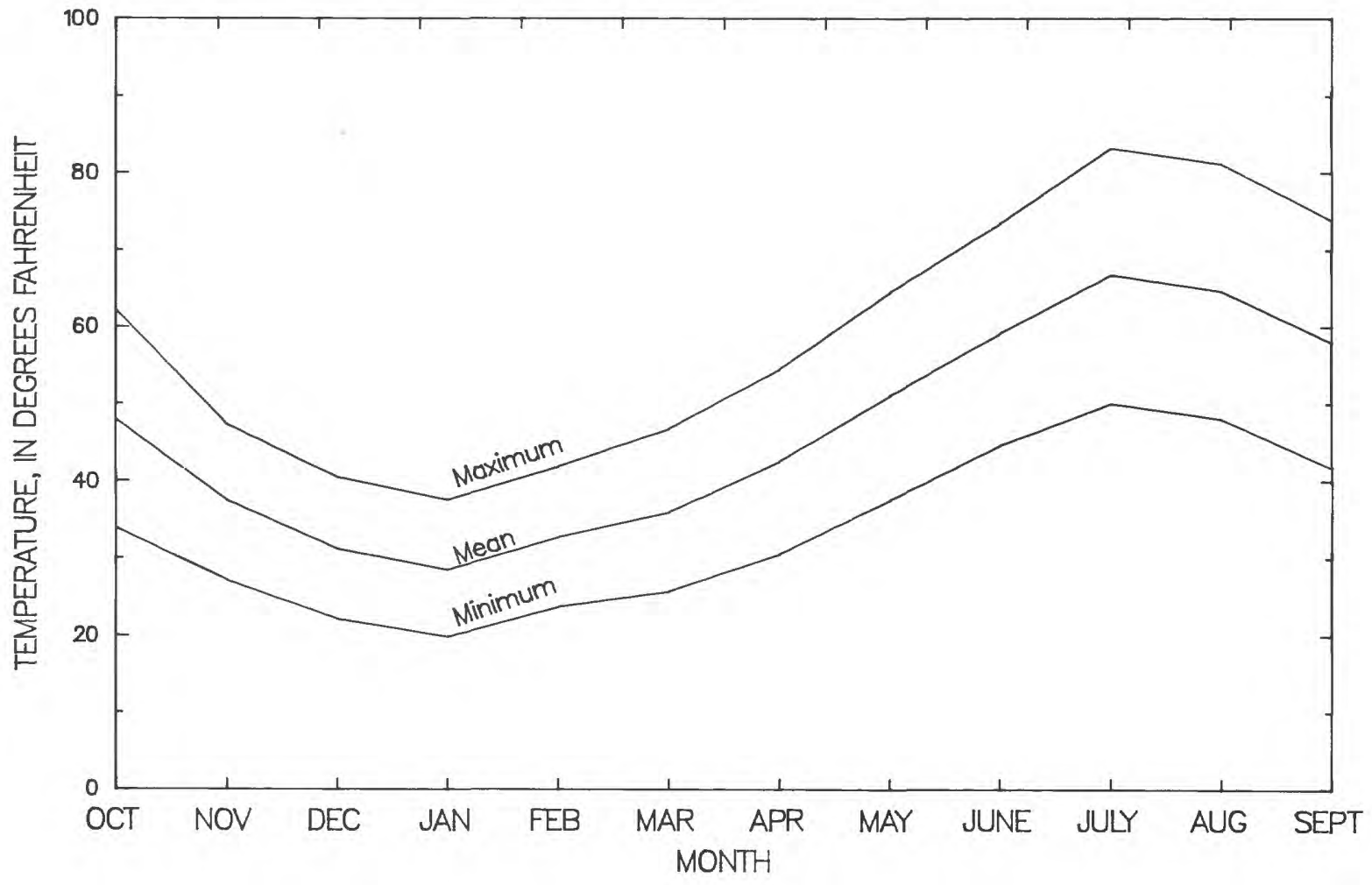

Figure 5b.--Monthly climatic data for Lakeview, 1954-80: Maximum, minimum, and mean temperature. 


\section{Previous Investigations}

The subject and scope of selected geologic, hydrologic, and general environmental studies of the Goose Lake basin and surrounding region are summarized below. These studies provided valuable data and background information for this investigation.

Waring (1908) included one of the earliest and most detailed descriptions of the geology and hydrology of the basin in his reconnaissance of south central Oregon, which covered most of Lake County. Extensive information on wells, springs, precipitation, and chemical quality of ground water was compiled for Lake County by Trauger (1950). Peterson (1959) described the geology of the uranium occurrences in the Lakeview area. The California Department of Water Resources (1963) reported on the geology and water resources of the California part of the basin and updated this report in 1982 with new data on water-level changes and pumpage. Walker's (1963) geologic map of the eastern part of the Klamath Falls quadrangle $(1: 250,000)$ includes the Oregon part of the basin. A report by Daum (1966) detailed the hydrology and water quality of Goose Lake; this work formed the basis for California's water-quality control policy for Goose Lake. A reconnaissance geologic map and a description of mineral resources were compiled by Peterson and McIntyre (1970) for eastern Klamath County and western Lake County. Phillips and Van Denburgh (1971) investigated the hydrology and geochemistry of Goose Lake, as well as that of Abert, Summer, and other closed-basin lakes in south-central Oregon. The natural resources of the Oregon portion of the basin were the subject of a U.S. Department of Agriculture study (USDA, 1978) to identify potential watershed projects. The geothermal resource potential of the Lakeview area was assessed by Peterson and others (1980); this report includes detailed geologic mapping of the Warner Mountains near Lakeview. Nebert (1985) developed a water-budget model for simulating historic fluctuations in the level of Goose Lake, using precipitation and runoff records reconstructed from tree-ring data.

\section{Scope and Methods of Investigation}

The primary subject of this report is the geohydrology of the alluvial aquifers that underlie the lower part of the basin: their hydraulic properties, their thickness and extent, the recharge to them, and the discharge from them. The upland and mountainous areas surrounding the valley floor were considered to the extent that available data allowed because of their potential contributions to recharge of the alluvial aquifer system. The majority of wells in the basin are located on the valley floor immediately north and northwest of Goose Lake; consequently more detailed study of this part of the valley floor was possible.

The general approach used in this study was to (1) gather all available data on the geology and hydrology of the basin, (2) supplement these data where needed and practical by collecting new data, (3) use these data to develop concepts of the ground-water flow system, (4) utilize these concepts to construct a preliminary numerical simulation model of the basin, (5) compare model results with observations of the flow system to determine if the model represents the system accurately enough to be used as a guide to managing the ground-water resource, and (6) determine what additional data would need to be collected to improve the model.

The major source of existing but unpublished data for this study was the records for more than 1,000 wells drilled in the basin. About 180 of the wells are in California. A computerized project database, designed for this study, was used to store most of the information contained in these well reports. Each well entered was assigned a unique identification number. Related data files containing information on the lithology, water rights, water levels, and pumpage for selected wells were also constructed. Each entry in the related files was keyed to a well driller report in the database by the identification number. The project database was implemented using the $\mathbb{I N F O}^{1}$ database management program, but all data can be converted to standard format files and transferred to other computers. The database is currently maintained at the Oregon State Office, U.S. Geological Survey, Water Resources Division, in Portland, Oregon.

1INFO is a trademark of Henco Software, Inc. The use of trade or product names in this report is for identification purposes only and does not constitute endorsement by the U.S. Geological Survey. 
Approximately 399 of the wells in the database have been located (visited) in the field. Of these, 239 were visited by Trauger (1951), about 20 wells were located in 1982 by OWRD personnel in the process of establishing a water-level observation network, 79 have been located in California by the California Department of Water Resources (CDWR), and 61 were field located for this study during April and July of 1986. Trauger (1950) measured the depth to water at nearly all of the wells listed in his report; however, many of the land-surface altitudes published in that report were measured with an aneroid barometer. These measurments were often found to be inaccurate when compared with known altitudes. Using Trauger's original field notes and location sketches, well locations were determined on the latest Geological Survey 1:24,000-scale topographic maps, and land-surface altitudes were adjusted if necessary. Land-surface altitudes at wells located by CDWR were surveyed, and those at OWRD- and Survey-located wells were determined from topographic maps having contour intervals of 10 or 20 feet (and some having supplemental 5-foot contours).

Twice-annual water-level measurements have been made by the OWRD at six wells since the mid1960's as part of a Statewide network. A local network, comprised of about 20 wells, has been measured up to twice per year since 1982 by the State Watermaster in Lakeview. The CDWR has monitored a 6- to 10well network twice annually since the 1960 's and has made many miscellaneous measurements for studies in 1966 and 1982. The locations of observation wells are shown on plate 1a.

Two series of water-level measurements were made during this study. The first was in April 1986, when measurements were made in 59 newly located wells and in OWRD's 20-well network. The second series of measurements was made in July 1986, when pumping levels were measured in 21 wells. Approximately 637 water-level measurements made between August 1957 and July 1986 at 124 wells are stored in the project database. Seventy of the wells measured are in California.

The geologic data from 161 of the most complete driller reports were entered in the project database and used extensively to delineate the distributions of fine- and coarse-grained alluvium and their hydraulic properties.

\section{Acknowledgments}

Dennis Glender, the Oregon State Watermaster in Lakeview, provided a great deal of assistance and a wide variety of information, including water-rights data and ground-water level and streamflow measurements. The California Department of Water Resources in Red Bluff, California, supplied groundwater level data and drillers' reports for wells in the California part of the basin. Jim Hays and Daniel Silveria of the Surprise Valley Electrification Corporation, Alturas, California, provided power-consumption records for irrigation pumps in the basin. Pumping-plant and irrigation-efficiency data, as well as information on soil properties, were supplied by William Schrader of the U.S. Soil Conservation Service in Lakeview. Gratitude is also due to the many residents of the Goose Lake basin who granted access to their wells and land for this study.

William D. McFarland of the U.S. Geological Survey, Portland, Oregon, made significant contributions to the model analysis performed in this study. Finally, Elnora Malpass and Ingrid Williams, formerly of the U.S. Geological Survey in Eugene, Oregon, are gratefully acknowledged for their important contributions in compiling the computer database that made much of this report possible.

\section{GEOLOGIC FRAMEWORK}

\section{Geologic Setting}

Goose Lake Valley is a structural basin bounded on the east and west by active normal faults and formed during the uplift of the adjacent Warner Mountains to the east and the unnamed upland region to the west of the valley. The surrounding mountains are comprised primarily of Tertiary tuffs, tuffaceous sedimentary rocks, andesite and basalt flows, and rhyo-dacitic intrusives. The basin has been filled by fluvial, 
lacustrine, and alluvial fan deposits derived from the surrounding mountains since the Pliocene Epoch. A generalized geologic map, compiled from the work of Walker (1963), Peterson and McIntyre (1970), Peterson and others (1980), and Gay and Aune (1958), is shown on plate 1a.

The region that is now Goose Lake basin underwent a period of vigorous volcanic activity from early Miocene through early Pliocene time. Over 13,000 feet of tuffs, basalt and andesite flows, and volcaniclastic sediments were deposited during this period. Concurrent with the later part of the Miocene and early Pliocene, large outpourings of basaltic lavas occurred and formed a coherent lava field stretching from the locale of Alturas, California, to Summer Lake in Oregon (McKee and others, 1983, p. 292).

North-northwest trending faults offset these basaltic plateaus during the Pliocene Epoch. These faults had small displacements relative to the northerly-trending Basin and Range faults, where movement first occurred in early Pleistocene. Faults of this age formed the major topographic features of the basin. Erosion of the uplifted blocks has filled the basin with up to 5,000 feet of fluvial and lacustrine sediments (Peterson and others, 1980, p. 5). The large intermittent lake or group of lakes that covered the basin during Pliocene time drained to the south toward the ancestral North Fork Pit River. Pleistocene basalt flows covered and lapped up on Tertiary basalts in the Devil's Garden area in the southeast part of the basin. Terrace and deltaic deposits were emplaced during this period of elevated lake levels. In association with the tectonic upheavals that occurred during the Pliocene and the early Pleistocene, a number of intrusive and extrusive eruptive centers developed in the basin.

\section{Lithologic Units and Their Hydrologic Character}

The rocks in the Goose Lake basin are divided into two broad lithologic classes: volcanic rocks and basin-fill deposits. As a class, the volcanic rocks are less permeable than the basin-fill deposits and are not generally important as a source of water to wells. Notable exceptions occur on the west side and south end of the valley floor, where wells that tap buried basalt flows commonly have high yields. In general, however, it is the upper 800 feet of unconsolidated sediments in the basin which yield the largest quantities of water to wells and have been most actively developed.

\section{Basin-fill Deposits}

Basin-fill deposits have been derived primarily from weathering and erosion of the surrounding volcanic uplands and consist of unconsolidated to partially consoldiated clays, silts, sands, and gravels.

The CDWR (1963, table 9) classified the Quaternary alluvial deposits in Goose Lake basin as nearshore, terrace, alluvial-fan, lake, and basin deposits. Older alluvium in the basin (map unit Qlo on plate 1a) is commonly composed of near-shore, terrace, and older lake deposits; younger alluvium (map unit Qal) includes primarily younger lake, fluvial, and alluvial-fan deposits.

The variety of depositional environments in the basin has created a body of alluvial sediments with an equally wide variety of lithologies and sorting indicies. The interbedded nature of sediments in Goose Lake basin results in zones of high and low permeability of limited areal extent with respect to the size of the basin. These zones also are characteristically thin or have thicknesses that vary greatly over small areas. Individual aquifers or confining beds underlying Goose Lake basin rarely can be traced more than a few hundred feet between wells.

The known thickness of basin-fill deposits is greatest on the east side of the basin, where Gulf Oil Company's Favell-Utley No. 1 well (39S/20E-17) penetrated approximately 5,000 feet of sediments before reaching the Tertiary volcanic rocks underlying the basin (Peterson and others, 1980, pl. 1a). Nearer the center of the basin, Lakeview Oil Company's No. 1 well (39S/19E-16) encountered basalt flows at the shallower depth of nearly 2,600 feet (Trauger, 1950, table 3 ). The apparent 7-degree eastward dip of the Tertiary volcanic surface is supported by gravity data presented by Peterson and others (1980, pl. 2). 
Tertiary volcanic rocks underlie the drainage divide of Goose Lake basin at all points except at the south end of the basin, where basin-fill deposits underlie a 5-mile segment of the divide. At depth, a larger segment of the boundary may consist of alluvium, since the Pliocene and Pleistocene basalts (QTb) exposed in this area are known to be interbedded with the basin-fill deposits. The minimum thickness of basin-fill deposits in the Davis Creek area is probably 600 to 700 feet; no wells in this area are known to have penetrated the Tertiary volcanic section.

Characterization of water-bearing capabilities of the basin-fill deposits was an important goal of this study, since these deposits have been the target of past ground-water development and have the greatest potential for future development. The primary factors affecting the ability of the basin-fill desposits to transmit water include particle size, degree of sorting, and degree of consolidation or cementation. To characterize the basin-fill deposits using these factors, well-log data were used to estimate the cumulative thickness of specific lithologies in the basin between depth intervals of 0 to 100 feet and 101 to 300 feet. These lithologies were then catagorized as either predominately "coarse-grained" or predominately "finegrained." Lithologic descriptions from 161 well logs were first interpreted and translated to a standard system of classification based on rock type and grain size. The classifications used are listed in table 1.

Table 1.--Lithologic classifications used to standardize geologic descriptions on driller-reports

\begin{tabular}{clll}
$\begin{array}{c}\text { Lithologic } \\
\text { code }\end{array}$ & $\begin{array}{c}\text { Lithologic } \\
\text { unit }\end{array}$ & $\begin{array}{l}\text { Grain } \\
\text { size }\end{array}$ & \multicolumn{1}{c}{ Description ${ }^{2}$} \\
\hline GL & Basin-fill & Coarse & Gravel and (or) cobbles \\
GS & Basin-fill & Coarse & Gravel with sand \\
SG & Basin-fill & Coarse & Sand and gravel \\
SD & Basin-fil & Coarse & Sand \\
GC & Basin-fill & Coarse & Gravel with clay and (or) silt \\
SC & Basin-fill & Coarse & Sand with silt and (or) clay \\
CG & Basin-fill & Fine & Clay or silt with gravel \\
CS & Basin-fill & Fine & Clay or silt with sand \\
CY & Basin-fill & Fine & Clay and (or) silt \\
TF & Volcanics & NA & Tuff, ash, pumice \\
BT & Volcanics & NA & Basalt, fractured basalt \\
RK & Volcanics & NA & Rock, consolidated rock \\
SL & NA & NA & Soil \\
\hline
\end{tabular}

1 Two-letter lithologic code entered in project database.

2 Typical description found in well $\log$.

The lithologic codes listed in table 1 were entered in the project database for each interval of each well. The total thickness of coarse- and fine-grained deposits between 0-100 feet and 101-300 feet were then summed at each well. Wells that did not penetrate at least 90 percent of an interval were not used. The cumulative thicknesses of coarse- and fine-grained sediments are shown in figures 6 ( 0 to 100 feet) and 7 (101 to 300 feet). 


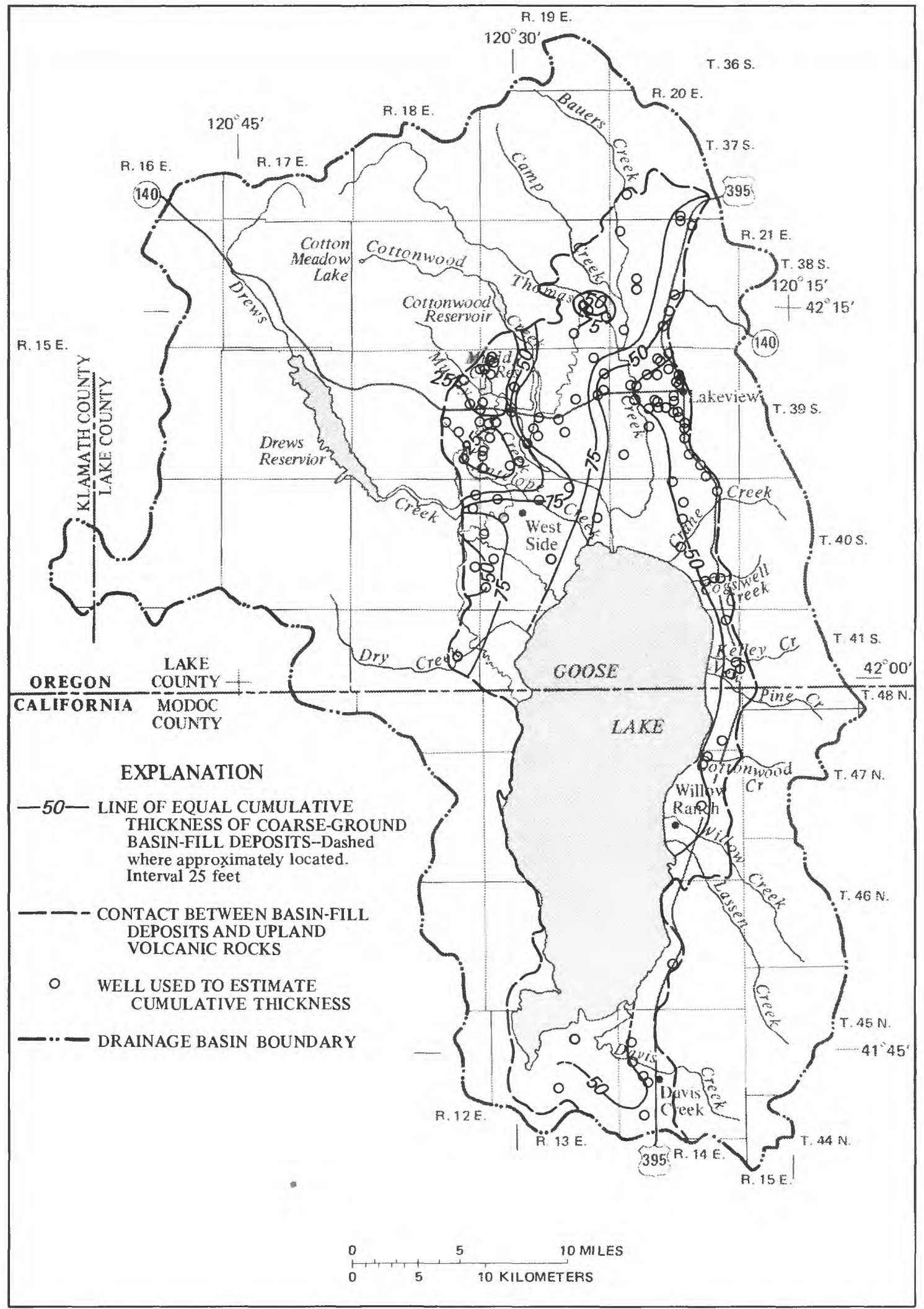

Figure 6.--Cumulative thickness of coarse-grained basin-fill deposits in the depth range 0 to 100 feet. 


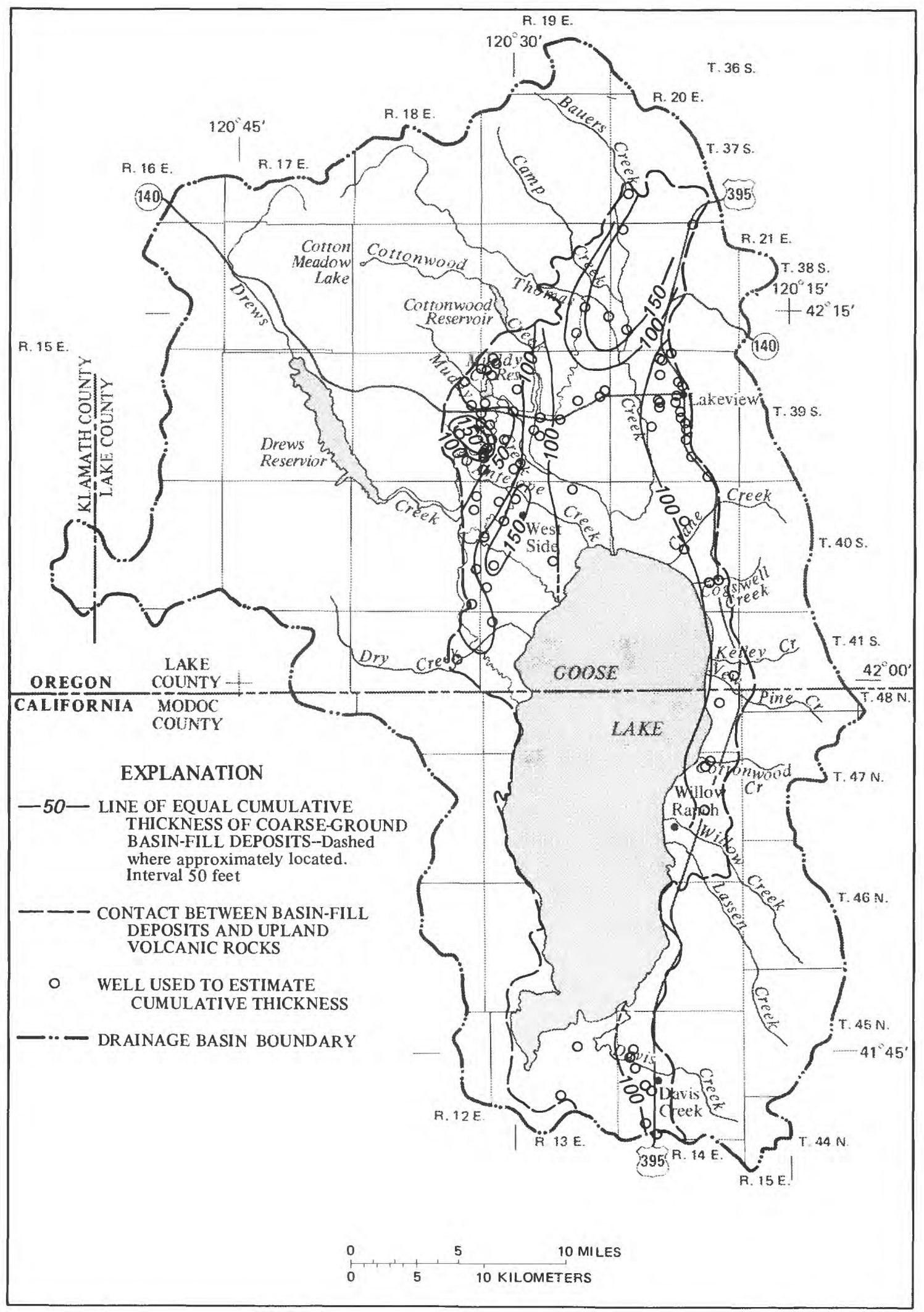

Figure 7.--Cumulative thickness of coarse-grained basin-fill deposits in the depth range $10 \mathrm{I}$ to 300 feet. 


\section{Volcanics}

Younger basalts (QTb on plate 1a) in the southern part of the basin are highly jointed and have vesicular scoriacious interflow zones that make them very permeable (California Department of Water Resources, 1963). They usually have a thin soil mantle and limited vegetation, making them likely recharge areas to adjacent alluvial aquifers. Areas where this unit is penetrated by wells near Davis Creek are shown in figure 8 .

On the northwest side of the valley, Tertiary age basalt flows are encountered by wells within 300 feet of land surface along a 2- to 3-mile wide zone that parallels the volcanics/basin-fill contact (fig. 8). Wells in this area generally have good yields (500-2,000 gallons per minute). The Tertiary volcanics unit crops out through a "window" in the overlying older alluvium (Qlo) in sections 13 and 24 of T.39S., R.18E. and in section 19 of T.39S., R.19E., suggesting a thin alluvial veneer in this area. Typical well construction in this zone is surface-casing to a depth of 20 to 30 feet and open-hole to the full depth of the well. This type of construction belies the consolidated nature of the deposits and further suggests that the wells in this area produce ground water from a thick sequence of partially- to fully-consolidated volcanic rocks. The narrow band of shallow basalt flows parallels the trend of normal faulting on the western edge of the basin. Peterson and others (1980) suggest that total vertical displacement on the west side of the basin is distributed across a series of step faults. Drillers' reports for wells in this area commonly describe "fractured basalts" as the principal aquifers. Basalts subjected to intense structural deformation in this area would be expected to have good secondary permeability due to fracturing.

A noteworthy feature shown in figure 8 is the apparent relation between the subsurface "topography" of the shallow basalts and the location of present-day drainages. The areas where basalts have been penetrated by wells within 300 feet of land surface lie between the drainages of Cottonwood (Oregon) and Davis Creeks and between the Davis and Dry Creek drainages. Basalts reported within 100 feet of land surface are less extensive, but lie similarly between the drainages of Muddy and Antelope Creeks and Davis and Dry Creeks. These relations indicate that prior to their burial by Pliocene and Pleistocene sediments, the exposed Tertiary volcanics were eroded by ancestral streams whose drainage patterns have not changed appreciably since late (?) Pleistocene.

\section{THE GROUND-WATER FLOW SYSTEM}

\section{Conceptual Model of the Flow System}

The following discussion summarizes the major hydrologic processes and concepts of the ground-water hydrology in the Goose Lake basin; detailed discussions of the basin's hydraulic characteristics, recharge, ground-water movement, discharge, and water level-changes are presented in following sections.

Two distinct areas characterize the Goose Lake basin: (1) the low-lying agricultural lands covering the valley floor and (2) the surrounding uplands, which comprise much of the recharge area within the basin. Upland areas are composed primarily of relatively low-permeability tuffaceous rocks and interbedded basalt flows and are essentially undeveloped with respect to ground water. The valley floor is underlain by a thick sequence of mostly unconsolidated basin-fill deposits which contain sands and gravels capable of transmitting large quantities of water. Fractured basalts underlying thin alluvial deposits on the northwestern margin of the valley also provide large quantities of water to wells. The general concepts of ground-water recharge, movement, and discharge in the basin are shown in figure 9.

The mountainous upland region is the major recharge area for the flow system. Approximately $200,000 \mathrm{acre}-\mathrm{ft} / \mathrm{yr}$ of rainfall and snowmelt infiltrate and percolate to the saturated zone in this region. An additional 20,000 acre-ft/yr of precipitation and irrigation water infiltrates sediments on the valley floor, bringing the total of recharge to 220,000 acre-ft/yr. Recharge also occurs from losing streams and irrigation canals; seepage rates are high where canals or streams cross permeable terraces and alluvial-fan deposits at the valley margin. At least 9,000 acre-ft/yr of irrigation diversions are lost from unlined canals. Recharge to 


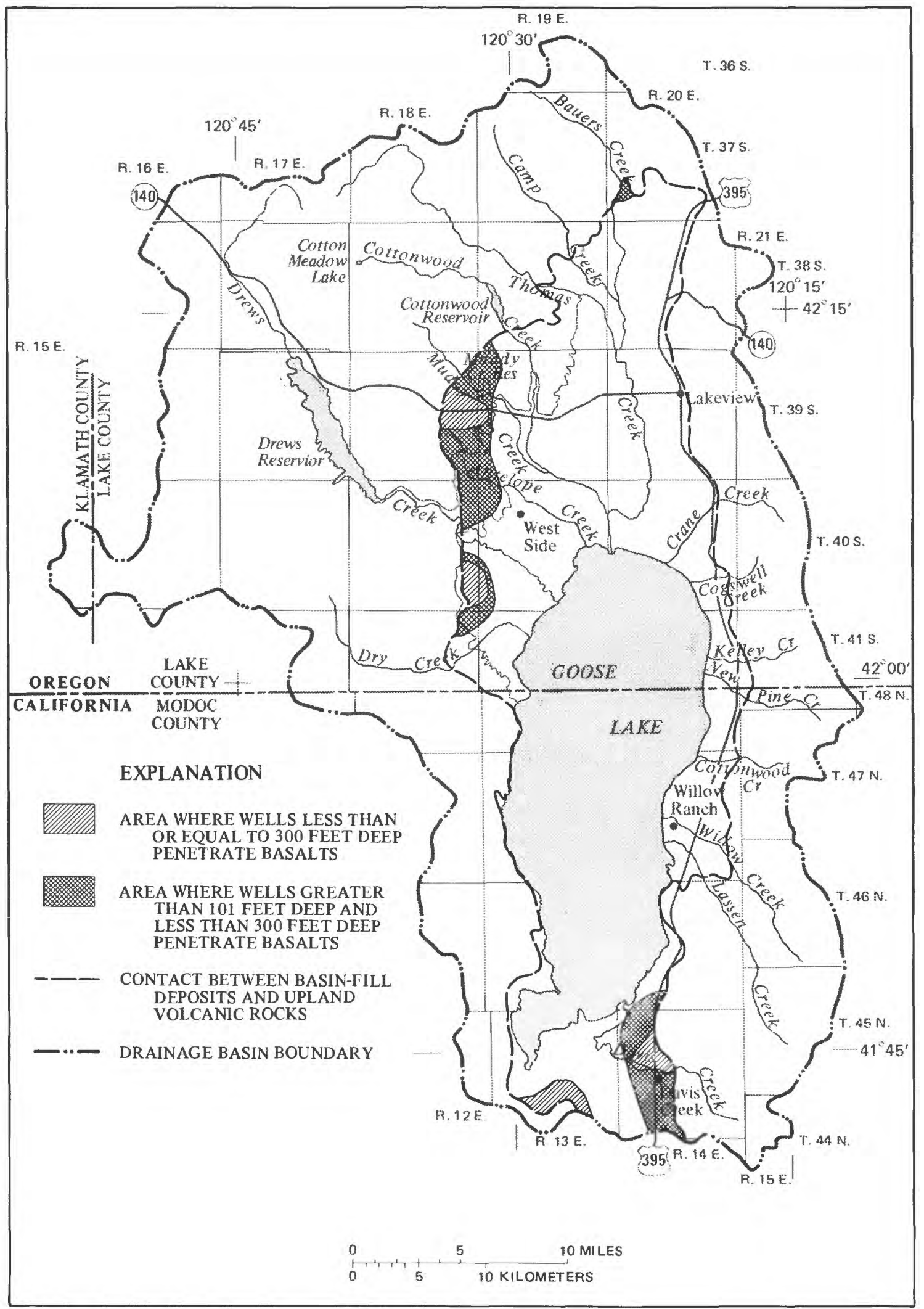

Figure 8. - Areas of the valley floor where basalts are penetrated by wells within a depth of 300 feet. 


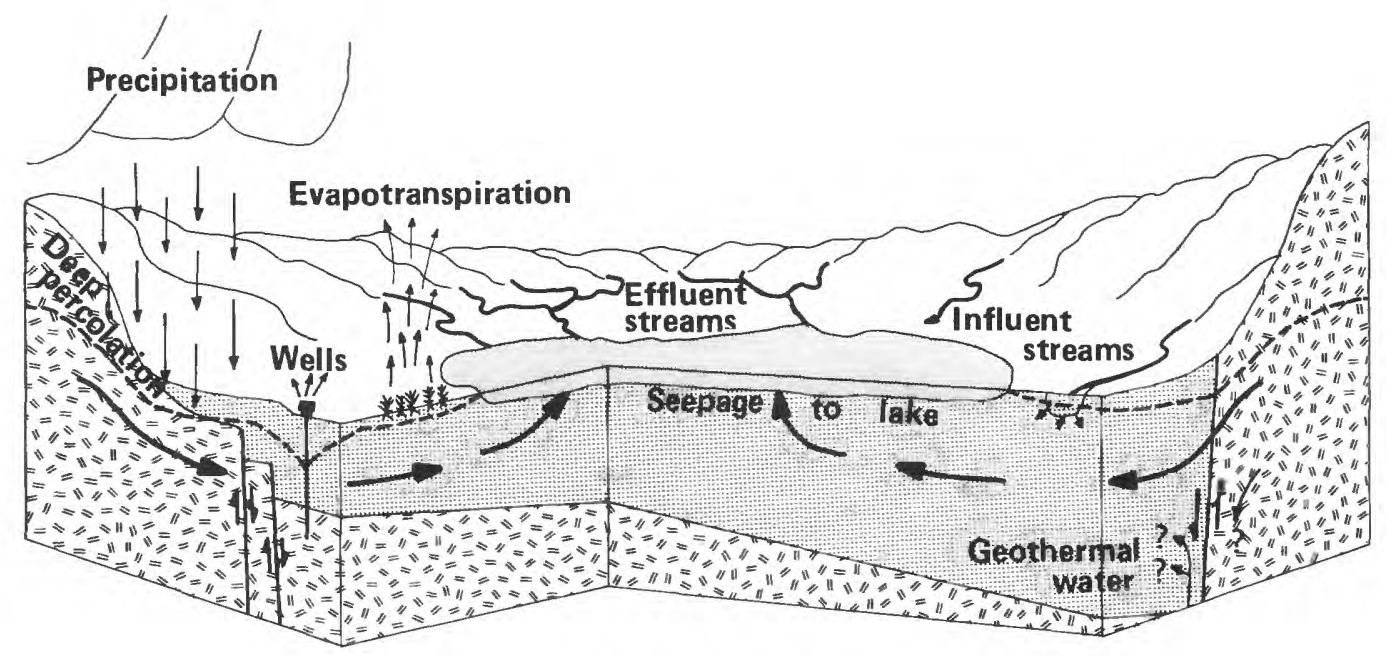

EXPLANATION

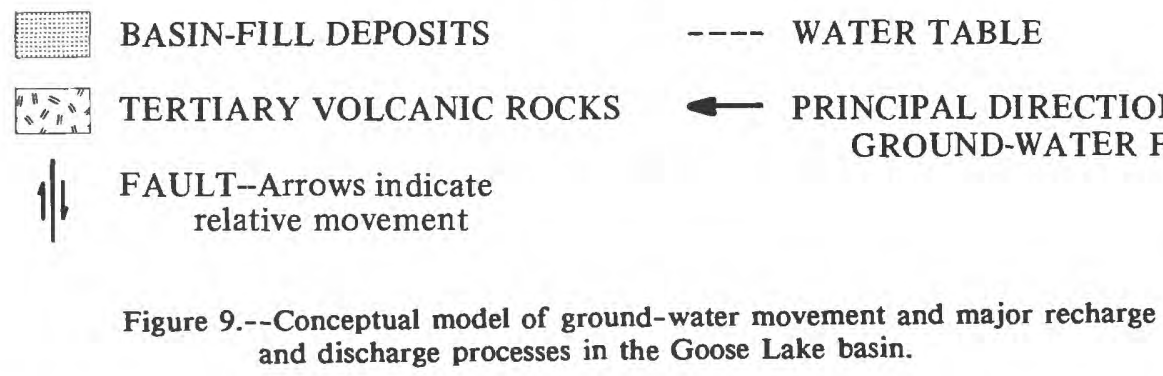

the shallow aquifers underlying the valley floor occurs as seasonal pulses during periods of high streamflow and the irrigation season. When considered on an annual basis, however, most of the valley floor is a groundwater discharge area.

Thermal ground water is common near Lakeview and appears to be associated with the rangefront fault that forms the west side of the Warner Mountains. Deep circulation of meteoric water is the probable source of the upflow (Peterson and others, 1980) and therefore would not represent additional recharge to the ground-water system. Even if regional, inter-basin flow were the source of fluid to the geothermal reservoir, calculations for a similar anomally in the nearby Warner Valley suggest that thermal-water upflow is only about 50 acre-ft/yr (Sammel and Craig, 1981, p. I42).

Regional hydraulic gradients are from the upland recharge areas toward the axis of the basin and the principal discharge area underlying and adjacent to Goose Lake. Local subsystems in the mountains discharge to lakes, reservoirs, wet meadows, and streams; however, large quantities of ground water move downgradient and enter unconsolidated sand and gravel deposits at the volcanics/basin-fill interface. Unconfined ground water commonly occurs within the upper 10 to 20 feet of saturated sediments on the valley floor. Confined conditions prevail with increasing depth; 100 feet below the water table, ground water is confined nearly everywhere in the basin-fill deposits. Movement in the basin-fill deposits is through complexly interbedded and discontinuous sands, gravels, silts, and clay. As it moves toward the center of the basin, ground water moves upward and is discharged via evapotranspiration, seepage to Goose Lake and streams, and wells. Seepage to Goose Lake and subsequent evaporation accounts for an estimated 130,000 acre$\mathrm{ft} / \mathrm{yr}$ of discharge from the basin; prior to ground-water development, the remaining $90,000 \mathrm{acre}-\mathrm{ft} / \mathrm{yr}$ of discharge (assuming recharge equal to discharge) was divided between evapotranspiration, seepage to streams, and perhaps subsurface outflow.

Ground-water withdrawals for irrigation increased rapidly during the 1970's and peaked in 1981. Average water-level declines of approximately 1 foot per year accompanied the increases in pumping. Indications are that pumping has declined steadily since 1981 to a level of $17,200 \mathrm{acre}-\mathrm{ft} / \mathrm{yr}$ in 1985 and that water levels have recovered accordingly. 


\title{
Hydraulic Characteristics
}

\author{
Hydraulic Conductivity
}

Hydraulic conductivity is the characteristic of a porous medium that describes its ability to transmit water and is expressed in units of length per unit time (for example, feet per day). If the hydraulic conductivity of an aquifer is equal to 1 foot per day (ft/d), the aquifer will transmit 1 cubic foot of water through a 1-square-foot area under a hydraulic gradient of 1 foot per foot, in a period of 1 day. The hydraulic conductivity of many geologic materials is vertically anisotropic; that is, ground water moves horizontally more easily than vertically. A study involving simulation of three-dimensional ground-water movement (such as this study) requires that both the vertical and horizontal components of hydraulic conductivity be estimated.

\section{Horizontal hydraulic conductivity}

Horizontal hydraulic conductivity of basin-fill deposits and basalts were estimated from well-yield test data reported in 238 driller reports. Only data from well-yield tests made with pumps (not bailer or "air" tests) with complete information on well construction (depth, depth cased, casing diameter, and perforated or screened intervals) were used. Values of transmissivity at each well were estimated using the Theis non-equilibrium equation and solving as suggested by Vorhis (1979). This method yields a solution to the Theis equation where transmissivity is expressed as a function of storage coefficient. Appropriate transmissivity values were selected by assuming a storage coefficient in the range normally assumed for confined aquifers $(0.001)$ for wells deeper than 100 feet and and one in the range normally assumed for unconfined aquifers $(0.1)$ for wells less than 100 feet deep. Average hydraulic conductivity was estimated for the deposits penetrated at each well by dividing estimated transmissivity by the length of the perforated and (or) uncased intervals of the well.

Hydraulic conductivities of the heterogeneous basin-fill deposits and basalts range from 0.01 to 500 $\mathrm{ft} / \mathrm{d}$, with a mean of $23 \mathrm{ft} / \mathrm{d}$. Assuming that well-yield data are collected and reported accurately, the principal sources or error using this approach are head losses due to poor well construction and uncertainty in storage coefficient estimates. Sensitivity analysis showed that transmissivities computed for a range of storage coefficients spanning three orders of magnitude $\left(10^{-1}\right.$ to $\left.10^{-4}\right)$ differed by an average of 33 percent. Uncertainty related to the storage coefficient is not considered an important source of error. Overestimation of hydraulic conductivity can occur using this method if a well only partially penetrates a thick, homogeneous aquifer in which substantial vertical flow toward the well can occur. The heterogeneity of basin-fill deposits in the Goose Lake basin suggests, however, that the effects of partial penetration can be ignored.

Individual estimates of horizontal hydraulic conductivity for predominately coarse-grained basin-fill deposits, predominately fine-grained basin-fill deposits, and basalts were made using the standardized lithologic logs stored in the project database for 79 of the wells having yield-test data. The 13 lithologic codes used to standardize the drillers' descriptions were assigned to the coarse, fine, or volcanic (basalt) categories as shown in table 1 . At each well the thickness of deposits in each category within the perforated and (or) uncased interval(s) were summed. The well was considered to produce primarily from coarse- or fine-grained deposits, based upon which category comprised the greater thickness of deposits adjacent to the perforated and uncased intervals of the well. Wells that penetrated basalts or had large uncased sections, indicating the presence of consolidated or partly-consolidated rocks, were assumed to produce primarily from basalts. Table 2 shows the mean horizontal hydraulic conductivities for principal lithologic units in the basin.

Considerable variation in hydraulic conductivity was found within each category, as evidenced by standard deviations that exceed the mean for each lithologic unit. The observed variance can be attributed to many influences, including (1) variance in the actual distribution, (2) inaccurate lithologic descriptions in drillers' logs, (3) errors in estimated horizontal hydraulic conductivity, and (4) improper assignment of lithologic codes to lithologic units. Other variables, such as well depth, yield and duration of test, and 
location in the basin, were assessed to determine possible effects on estimated horizontal hydraulic conductivity; scatter plots of hydraulic conductivity versus each variable did not disclose any relations. An analysis of variance showed that the differences in the mean horizontal hydraulic conductivity are significant among the three lithologic units. The variance between groups classified as coarse, fine, or basalt is nearly four times the variance of hydraulic conductivities within groups. The probability of obtaining a ratio this high if all wells were completed in the same unit is only 0.02 . Frequency-distribution curves of hydraulic conductivity for each unit are shown in figure 10.

Table 2.--Horizontal hydraulic conductivity estimates for principal lithologic units found in Goose Lake basin [N = number of samples; $\mathrm{K}$ = horizontal hydraulic conductivity, in feet per day]

\begin{tabular}{|c|c|c|c|c|c|c|}
\hline $\begin{array}{l}\text { Lithologic } \\
\text { category }\end{array}$ & $\mathrm{N}$ & $\begin{array}{c}\text { Mean } \\
\mathbf{K}\end{array}$ & $\begin{array}{l}\text { Standard } \\
\text { deviation }\end{array}$ & $\begin{array}{c}\text { Median } \\
\text { K }\end{array}$ & $\begin{array}{c}\text { Minimum } \\
\mathrm{K}\end{array}$ & $\begin{array}{c}\text { Maximum } \\
\mathrm{K}\end{array}$ \\
\hline $\begin{array}{l}\text { Coarse } \\
\text { basin-fill }\end{array}$ & 34 & 21 & 30 & 9.1 & 0.03 & 140 \\
\hline $\begin{array}{l}\text { Fine } \\
\text { basin-fill }\end{array}$ & 25 & 7.5 & 9.9 & 3.5 & 0.16 & 38 \\
\hline Basalts & 20 & 30 & 34 & 18 & 0.01 & 46 \\
\hline All $^{1}$ & 238 & 23 & & 8.3 & 0.01 & 581 \\
\hline
\end{tabular}

1 Includes data from 159 tests not assigned to a lithologic catagory.

Relatively few wells are drilled in the upland areas underlain by volcanic rocks. Wells drilled in these areas usually obtain sufficient quantities of water for domestic and stock watering needs. Well-test data therefore are rare for the upland volcanics. However, three wells (39S/17E-02CC, 39S/17E-02CD, and $38 \mathrm{~S} / 17 \mathrm{E}-16 \mathrm{CD}$ ) in the upland volcanics are completed in fractured basalts and thin gravel units separated by glassy intrusives and tuffs. The estimated hydraulic conductivity of the upland volcanic sequences at these wells range from 0.1 to $3 \mathrm{ft} / \mathrm{d}$.

\section{Vertical hydraulic conductivity}

The layered heterogeneity of the basin-fill desposits imparts considerable anisotropy to the deposits on a regional scale. Few field data exist to quantify this relation; however, two aquifer tests conducted at the site of a former uranium processing mill (T.39S, R.20E, section 4) yielded vertical hydraulic conductivity estimates of 0.02 and $3.0 \mathrm{ft} / \mathrm{d}$ for deposits ranging from silt to sand and gravel within 80 feet of land surface. Horizontal hydraulic conductivities computed from the same tests were 3.4 and $6.9 \mathrm{ft} / \mathrm{d}$, suggesting vertical anisotropy ratios of from 2:1 to 170:1 (U.S. Department of Energy, 1985). These ratios are similar to those found in other alluvial basins (Freeze and Cherry, 1979, p. 34) and, although site-specific, probably are representative of conditions found basin-wide.

A high degree of anisotropy is also characteristic of the volcanic rocks found in the basin. Flow centers in the Pliocene and Pleistocene basalts encountered by many wells in the southern part of the basin are dense and massive; in contrast, many interflow zones are vesicular and scoriacious. The predominant direction of ground-water flow is horizontal; however, where basalt flows are broken by faulting, as they are along the western edge of the valley, ground water may move vertically through joints and fracture zones.

Good estimates of vertical hydraulic conductivity are best obtained from well designed aquifer tests. In the absence of such data, numerical simulation models have been used to estimate effective regional vertical leakance. 


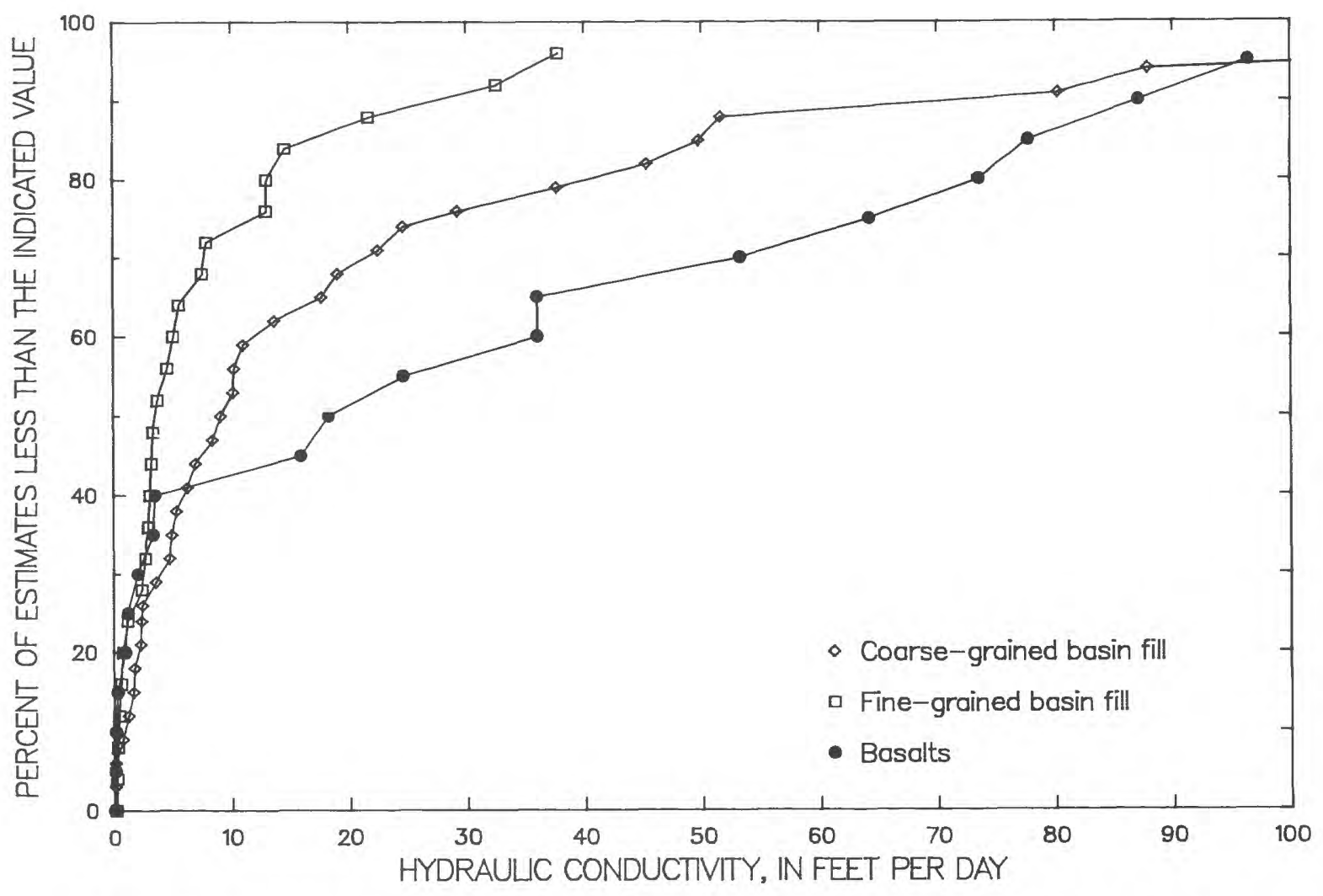

Figure 10.--Frequency distribution of estimated horizontal hydraulic conductivity for basalts and coarse- and fine-grained basin-fill deposits.

\section{Specific Storage and Yield}

The specific storage of a confined aquifer is defined as the volume of water that a unit volume of aquifer releases from storage under a unit decline in hydraulic head (Freeze and Cherry, 1979, p. 58). The water released is derived from expansion of the water and compression of the aquifer and adjacent and interbedded clay layers. Specific yield defines the volume of water released from storage in an unconfined aquifer per unit surface area of aquifer per unit decline in the water table. The water released from storage in an unconfined aquifer is mostly derived from gravity drainage of pore spaces in the aquifer, although the expansion of water and compression of the aquifer also contribute small amounts. Knowledge of an aquifer's storage properties is essential to predicting the time-dependent effects of ground-water withdrawals.

Specific storage is dependent primarily upon the compressibility and porosity of the aquifer. Compression of coarse-grained aquifers is mostly elastic, or recoverable, whereas aquifers containing thick, fine-grained beds may undergo inelastic compaction, which is largely non-recoverable. Specific storage values for aquifers undergoing inelastic compaction are much greater than those for aquifers where compaction is elastic. Estimated elastic specific storage values for unconsolidated deposits in the San Joaquin Valley of California range from $1 \times 10^{-6}$ per foot, for coarse-grained deposits (McClelland, 1963), to $5 \times 10^{-6}$ per foot for fine-grained deposits (Helm, 1978, p. 193). In contrast, the mean inelastic specific storage of fine-grained deposits estimated by Helm (1978, p. 193) was $3 \times 10^{-4}$ per foot.

Specific yield of an aquifer is strongly related to grain size, degree of sorting, and porosity. Clay lenses or cementation may greatly reduce the rate at which unconfined aquifers release water from storage. Average values of specific yield range from 0.02 for clay to nearly 0.3 for coarse sand (Johnson, 1967, p. 70). The cumulative thicknesses of fine-grained and coarse-grained sediments in the upper 100 feet of basin-fill deposits (fig. 6) therefore indicates the general distribution of specific yield values in the basin. 


\section{$\underline{\text { Recharge }}$}

Recharge to the Goose Lake ground-water basin occurs by (1) infiltration of precipitation and excess irrigation water and (2) leakage from streams and canals. The most important of these sources is direct infiltration of precipitation to the saturated ground-water flow system. Existing data were available to support a detailed study of recharge from this source, which is summarized in the following sections and discussed in detail in Appendix I. Recharge from stream and canal leakage was assessed in a less rigorous fashion because of limitations of available data.

\section{Deep Percolation of Precipitation and Irrigation Water}

Estimates of average annual recharge to the ground-water system from direct infiltration of precipitation and irrigation water were made using moisture and energy balance methods. The moisture and energy-balance equations were solved using a computer program, or model, referred to as the Deep Percolation Model for estimating Ground-Water Recharge--"DPM-GWR" (Bauer and Vaccaro, 1987). Technical details regarding the methodology employed by the model and its application to the Goose Lake basin are given in Appendix I.

The moisture balance was solved for subvolumes of the basin which were assumed to be homogeneous with respect to soil type, slope, altitude, vegetation, and other characteristics that affect evaporation and transpiration. Approximately 1,070 equal-sized rectangular subvolumes, or cells, were used to represent land areas of the basin (fig. 11). Conceptually, each cell was bounded vertically by (1) the top of the vegetative canopy and (2) the bottom of the root zone or soil zone, whichever was shallower. The following processes were simulated to account for transference of moisture and energy between each cell, the atmosphere, and the ground-water system: soil-moisture accumulation and depletion; evaporation from bare soil; plant transpiration; surface-water runoff; accumulation, sublimation, and melting of snow; and accumulation and evaporation of intercepted moisture.

Any moisture that reached the soil zone and exceeded evaporation and transpiration demands was considered to percolate below the root zone. Deep percolation was estimated for each cell on a daily basis for the calendar-year period 1954-1980. It was assumed for this study that the estimated average annual rate of deep percolation was equivalent to average annual recharge to the saturated ground-water system. Natural systems are extremely complex, however, and some portion of computed deep percolation no doubt reemerges via springs or seeps and is subjected to further evapotranspiration losses or becomes streamflow. A long (27-year) period of observed climatic record was used as input to the model to dampen the effects of climatic variation on results--much as these effects are attenuated by long periods of time required for groundwater to move through natural systems.

The effects of uncertainty in streamflow data and estimated irrigation-application rates on estimated recharge were investigated through a sensitivity analysis of the DPM-GWR. Daily streamflow to Goose Lake and the average monthly part of streamflow derived from ground-water (baseflow) must be supplied by the user of DPM-GWR (see Appendix 1). Estimates of both streamflow and baseflow are subject to large uncertainties when considered at a regional scale as they were in this analysis. The impact of irrigation on recharge was assessed by first simulating natural (non-irrigated) conditions and then introducing irrigated crops and levels of irrigation prior to and following ground-water development. Prior to ground-water development nearly all irrigation was derived from streams.

A summary of the results of five recharge-model simulations is shown in table 3 . These five simulations were made to determine the effects of uncertainty in streamflow and baseflow estimates (runs 2 and 3) and irrigation rates (runs 4 and 5) on mean annual recharge from deep percolation of precipitation and irrigation water. A "baseline" simulation (run 1) was made by using best available estimates of streamflow, baseflow, and irrigation rates for the period prior to ground-water development. 


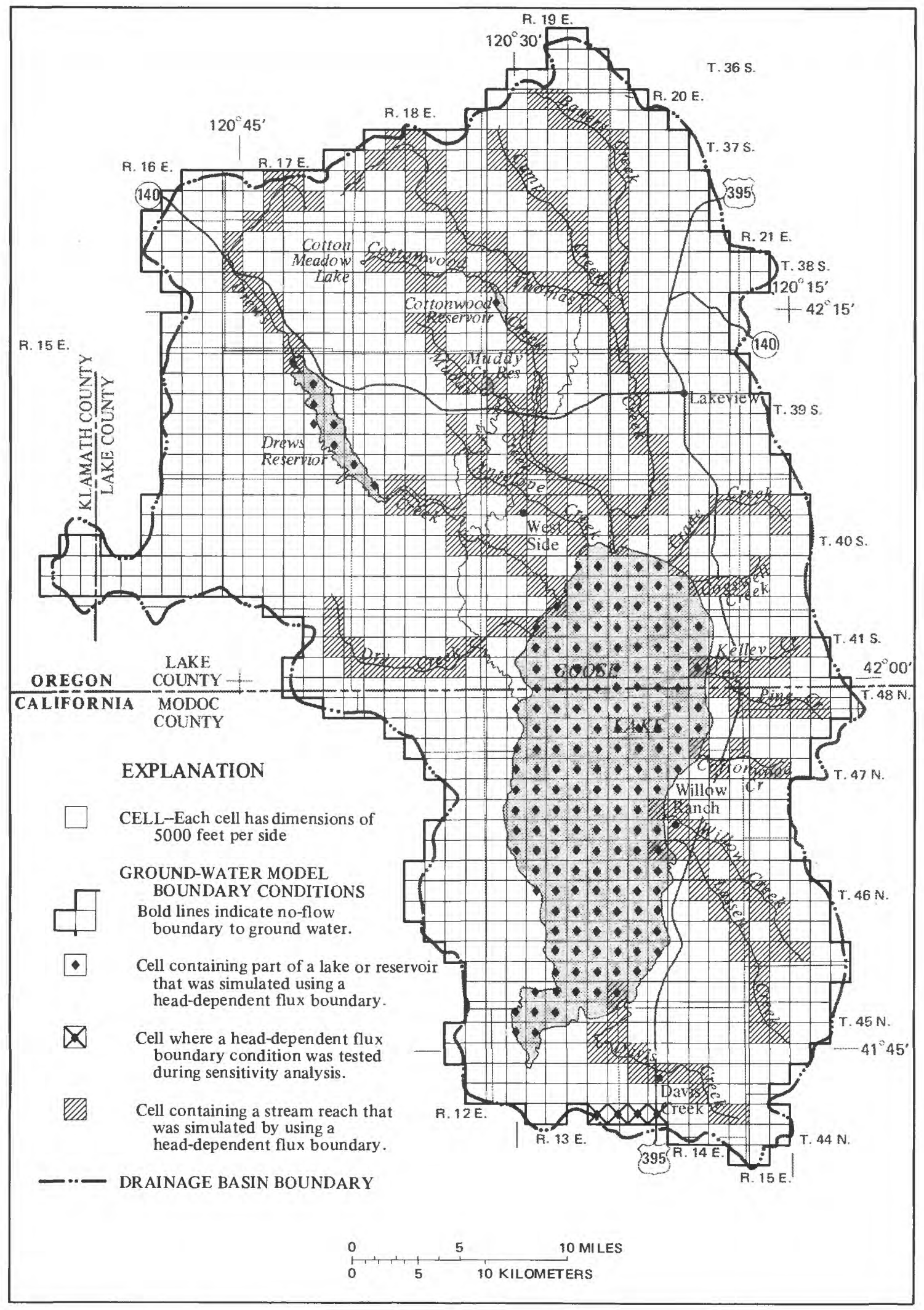

Figure 11.--Grid used to subdivide the basin for the recharge and ground-water models. 
[All budget items are in thousands of acre-feet per year. Estimates are based on 1954-80 climatic data. ET = evapotranspiration]

$\begin{array}{lllcccc} & & & & & \text { Deep } & \text { Unaccounted- } \\ \text { Simulation } & \text { Precip- } & \text { Irriga- } & \text { Total }^{1} & \text { Stream- } & \text { perco- } & \text { for } \\ & \text { itation } & \text { tion } & \text { ET } & \text { flow } & \text { lation } & \text { streamflow }\end{array}$

\begin{tabular}{lrrrrrr} 
1. Baseline & 925 & 130 & 740 & 95 & 220 & 15 \\
2. Zero runoff & 925 & 130 & 750 & 0 & 305 & 0 \\
3. Zero baseflow & 925 & 130 & 715 & 170 & 170 & 47 \\
$\begin{array}{l}\text { 4. Zero irrigation } \\
\text { 5. Maximum }\end{array}$ & 925 & 0 & 625 & 81 & 220 & 11 \\
\multicolumn{1}{c}{$\quad$ irrigation $^{2}$} & 925 & 165 & 765 & 95 & 230 & 13
\end{tabular}

\footnotetext{
${ }^{1}$ Includes plant transpiration, evaporation from bare soils, evaporation of intercepted precipitation, and sublimation of snow.

${ }^{2}$ Includes irrigation from both surface water $(130,000$ acre- $\mathrm{ft} / \mathrm{yr})$ and ground water $(35,000 \mathrm{acre}-\mathrm{ft} / \mathrm{yr})$.
}

Mean annual precipitation on the basin during the period was 925,000 acre- $\mathrm{ft} / \mathrm{yr}$. For baseline conditions, an additional 130,000 acre-ft/yr of irrigation water was assumed to be diverted from streams and applied to crops. Total estimated losses by evapotranspiration (ET) averaged 740,000 acre-ft/yr, mostly due to plant transpiration and evaporation of intercepted moisture. Mean annual runoff was $95,000 \mathrm{acre}-\mathrm{ft} / \mathrm{yr}$. The balance, about 220,000 acre-ft/yr, amounts to "excess" precipitation and irrigation water and is assumed to percolate to the saturated ground-water flow system. Only 20,000 acre-ft/yr of recharge occurs through alluvial deposits on the valley floor; the remaining 200,000 acre- $\mathrm{ft} / \mathrm{yr}$ infiltrates volcanic deposits in the surrounding upland areas.

The last column in table 3 lists streamflow in the basin that could not be accounted for by the DPMGWR model. Unaccounted-for streamflow is accumulated by the model on days when estimated streamflow exceeds moisture available from precipitation and (or) snowmelt. Some portion of the unaccounted-for streamflow is related to errors in the synthesized streamflow data for the basin (see Appendix I). Indirect or delayed streamflow probably also explains some of the discrepancy (Bauer and Vaccaro, 1987); therefore, the model reduces soil moisture to as much as $\mathbf{5 0}$ percent of capacity in order to generate the observed streamflow. Streamflow that could not be accounted for in the baseline simulation, even after removing water from soil moisture, averaged 15,000 acre-ft/yr.

Monthly recharge rates generally peak between December and March, when precipitation and snowmelt rates are high and potential evapotranspiration (PET) is low. Figure 12 depicts the mean-monthly basin-wide hydrologic mass balance for the root zone using baseline conditions, 1954-80. Maximum PET of 9 inches per month (in/mo) occurs in July; however, figure 12 shows that actual evapotranspiration (AET) peaks in May, utilizing soil moisture storage and late spring precipitation. Once soil moisture is depleted, AET is limited by available precipitation and irrigation; recharge during these months (July-September) is essentially zero. Soil moisture supplies are replenished primarily during the wet months of October through December, when temperatures are still warm enough that much of the precipitation falls as rain. 


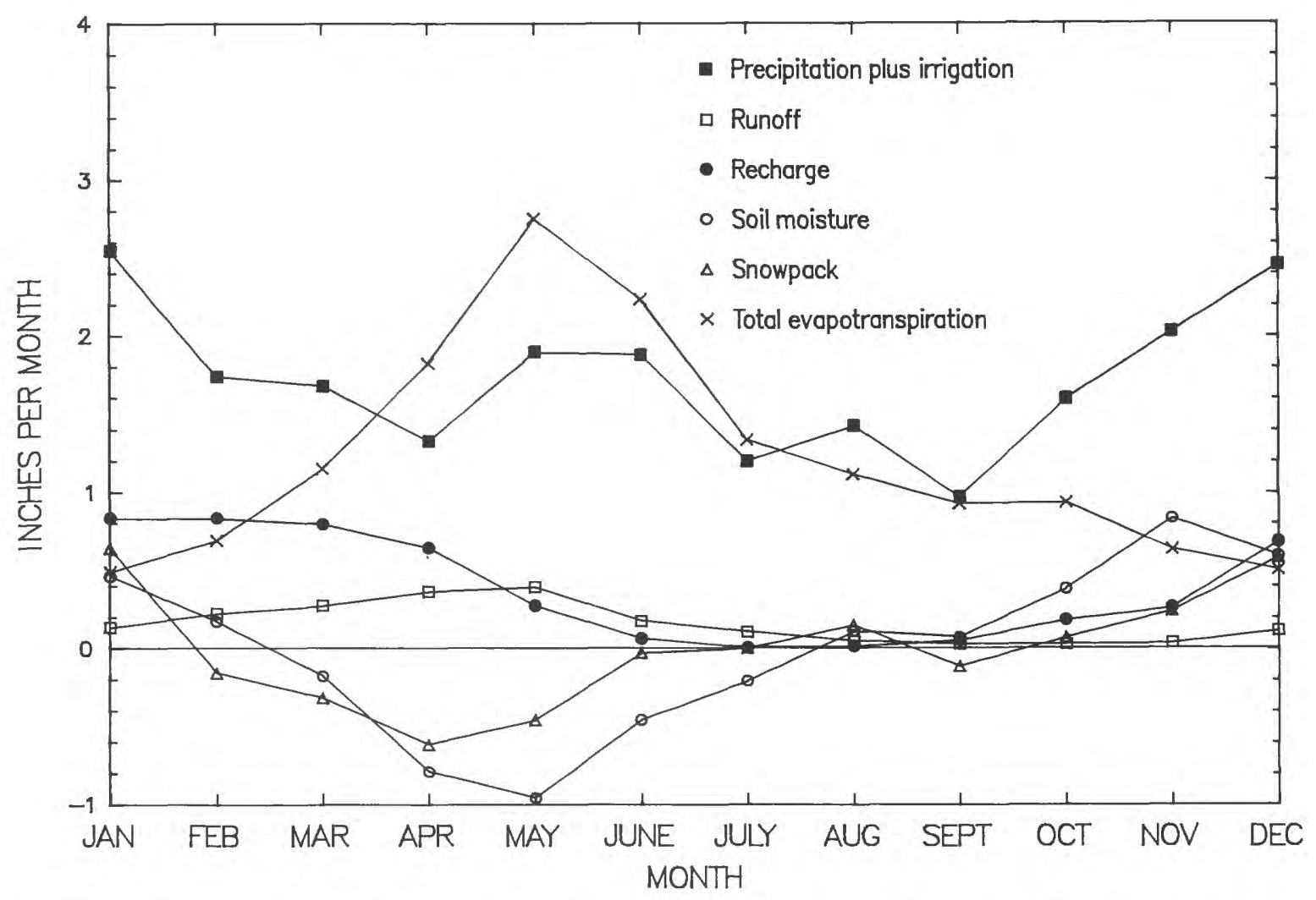

Figure 12.--Mean-monthly hydrologic mass-balance within the root zone, 1954-1980 climatic conditions.

The areal distributions of estimated average annual recharge (fig. 13) and average annual precipitation (fig. 4) are similar; both are stongly related to topography. The lowest recharge rates are on the basin floor and range from 0 to 2 inches per year (in/yr). Maximum recharge rates of 10 to $11 \mathrm{in} / \mathrm{yr}$ occur in the upper elevations of the Warner Mountains and Fremont Mountains.

Estimates of recharge were made for conditions where (1) runoff was assumed to be zero (simulation 2 ) and (2) baseflow was assumed to be zero (simulation 3). These estimates are, respectively, the maximum and minimum recharge rates that would result from erroneous estimates of streamflow and baseflow in the basin. Obviously neither estimated streamflow nor baseflow have such large uncertainty that actual values could be zero. When no baseflow is subtracted from observed streamflow, average annual recharge is 170,000 acre-ft/yr, or 23 percent less than the baseline estimate. If all precipitation either is lost by ET or becomes recharge (zero streamflow), average annual recharge is 38 percent above the baseline, or 305,000 acre-ft/yr. As shown in table 3, large quantities of streamflow are not accounted for when baseflow is equal to zero.

Estimates of recharge were also made for three levels of irrigation: (1) zero irrigation (simulation 4), (2) irrigation primarily from surface-water sources only (baseline simulation), and (3) irrigation from both ground-water and surface-water sources (simulation 5). Annual irrigation application rates for simulations 4 and 5 were 130,000 acre-ft/yr and 165,000 acre-ft/yr respectively. The derivation of these estimates is explained in Appendix I. Results of these simulations (table 3) show that recharge rates are unaffected by irrigation of up to $130,000 \mathrm{acre}-\mathrm{ft} / \mathrm{yr}$; at the elevated rate of $165,000 \mathrm{acre}-\mathrm{ft} / \mathrm{yr}$, however, an additional 10,000 acre-ft/yr of recharge was estimated. These results may be misleading due to the methods and assumptions used to distribute the irrigation over time and space.

Annual irrigation rates were used with monthly irrigation pumping data to compute daily irrigation rates during the irrigation season (May through September). This method gave equal daily application rates during each month. Typical irrigation practices are to apply large quantities of water over a 1- to 2-day period and then apply none for several days. This practice benefits crops and soils and is also conducive to 


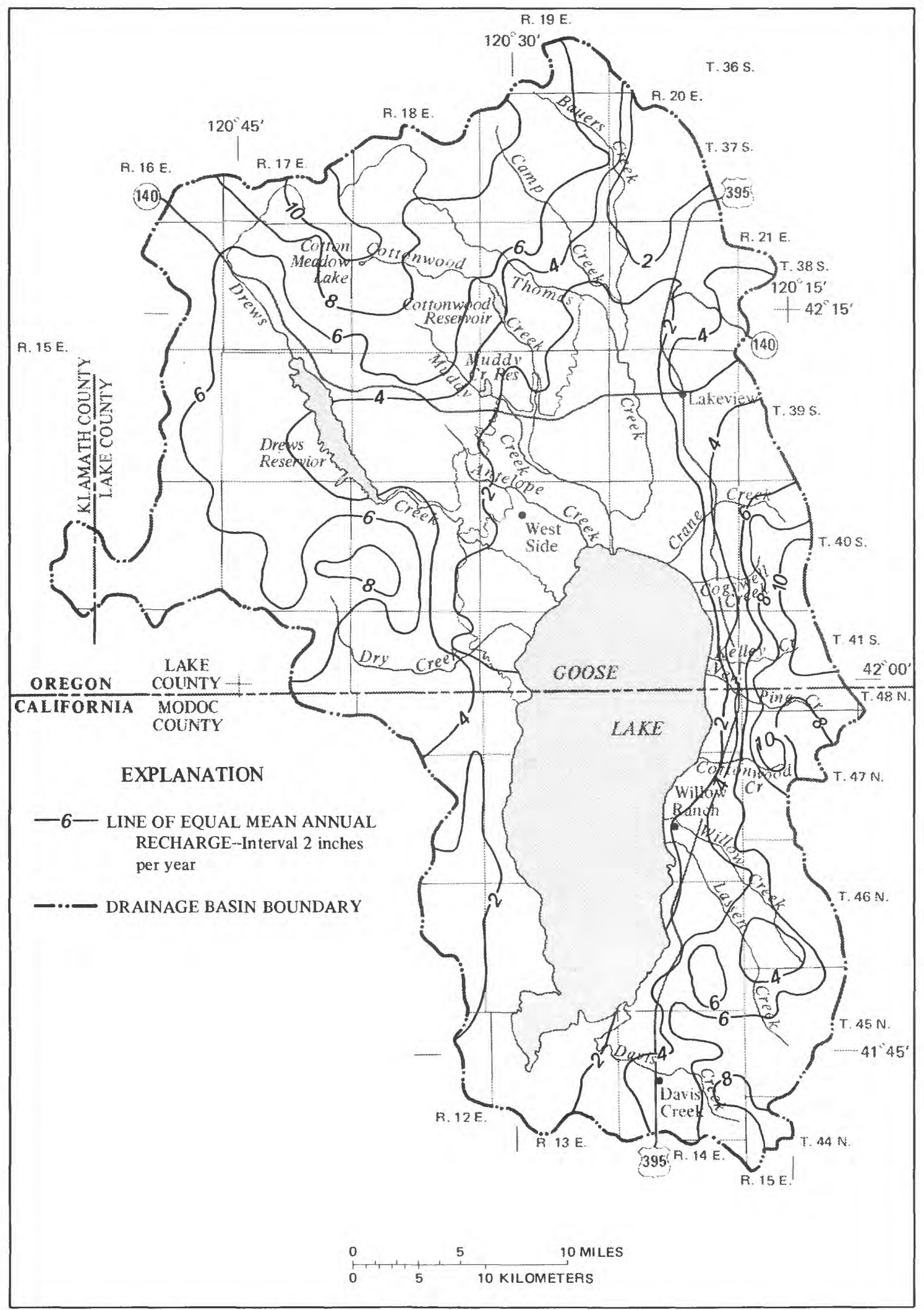

Figure 13.--Mean annual recharge from deep percolation of precipitation and irrigation water for 1954-1980 climatic conditions and irrigation from surface-water sources only. 
deep percolation since soil water-holding capacities are more rapidly exceeded by intensive irrigation. Equal daily irrigation application rates do not replenish soil moisture storage rapidly enough to exceed crop evapotranspiration demands and little or no moisture percolates below the root zone to become recharge. Underestimation of recharge results from poor knowledge of actual irrigation schedules and rates.

The increase in total annual irrigation in the basin from 130,000 acre-ft to 165,000 acre-ft was implemented by increasing the annual rate at each irrigated cell by 27 percent (from $36 \mathrm{in} / \mathrm{yr}$ to $45 \mathrm{in} / \mathrm{yr}$ ). Conceptually, the purpose of increasing total irrigation was to show the effect on recharge of irrigating additional acreage. Currently available data, however, did not allow an accurate separation of irrigated acreage by time period. The result of increasing rates by 27 percent $(35,000$ acre-ft) is significant, however, as it shows that nearly 30 percent of the additional water $(10,000 \mathrm{acre}-\mathrm{ft})$ percolates below the roòt zone.

The methods employed by the DPM-GWR (see Appendix I and Bauer and Vaccaro, 1987) are based on widely used and accepted empirical relations between the climate, topography, soils, and vegetation of a basin and exchange of moisture between plants, soils, and atmosphere. Nonetheless, these methods are subject to some error and ideally results should be compared with estimates obtained by other methods. Other techniques for estimating regional ground-water recharge (Watson and others, 1976; Maxey and Eakin, 1949; Mendel and Shiften, 1981) were deemed either inappropriate for hydrologic conditions found in the basin or infeasible due to lack of data. Site-specific methods of recharge estimation were not applied because (1) datacollection requirements were beyond the scope of this study and (2) a regional estimate was needed for a numerical analysis of the ground-water system.

Data errors also increase the uncertainty of recharge estimates made using DPM-GWR. Only the potential uncertainty in recharge estimates related to errors in surface-water runoff data and irrigation data were quantitatively assessed in this analysis. A qualitative estimate of model sensitivity to soil waterholding capacity data indicated that, even if capacities were systematically underestimated in the baseline simulation, recharge was probably not overestimated by more than 10 to 15 percent. Other sources of error, such as soil and root-depth data, were not addressed by this analysis, but do contribute to uncertainty in the estimates of recharge.

Finally, the DPM-GWR model is based on the assumption that precipitation, irrigation, and soilmoisture storage are the only sources of moisture available for evapotranspiration. Where the water table is near land surface, as it is under large areas of the valley floor in the Goose Lake basin, water will move upward from the saturated zone to the root zone if ET rates are moisture-limited. Under these conditions, the assumption of the DPM-GWR model is violated and recharge and (or) ET may be underestimated by the model. This is probably not an important source of error because (1) estimated recharge on the valley floor is only 10 percent of the total and (2) underestimation of recharge and ET are offsetting errors, and the net effect on estimated recharge may be quite small.

\section{Stream and Canal Leakage}

Streamflow and water diverted for irrigation also recharge the shallow aquifer system in the Goose Lake basin. In addition to the several natural stream channels that traverse the valley floor for several miles before discharging into Goose Lake, an extensive network of canals has been constructed to convey irrigation water within the basin. The major canals on the Oregon side of the basin are the North, South, and Middle Canals, which distribute water from Drews and Cottonwood Reservoirs. Not enough information is available to quantify the recharge from stream and canal losses; however, seepage data collected for this study indicate, at a reconnaissance level, relations between ground water and surface water for low-flow conditions. Estimates of losses on the main-stem canals also are possible from records of diversions to canals versus actual head-gate deliveries.

In August 1986, seepage measurements were made by Geological Survey personnel on reaches of Thomas, Cottonwood (Oregon), Dry, Crane, and Lassen Creeks and on a reach of the North Canal. The data collected are summarized in table 4; measurement sites are shown on plate 1a. The streams and reaches were 
[All values in cubic feet per second $\left(\mathrm{ft}^{3} / \mathrm{s}\right)$ unless otherwise stated; IRF indicates irrigation return flow to stream that was observed but was not measureable

\begin{tabular}{|c|c|c|c|c|c|c|c|c|c|c|}
\hline Stream & $\begin{array}{l}\text { Site } \\
\text { identi- } \\
\text { fication } 1\end{array}$ & $\begin{array}{l}\text { Dis- } \\
\text { charge } 2\end{array}$ & $\begin{array}{l}\text { Trib- } \\
\text { utary } \\
\text { inflow }\end{array}$ & $\begin{array}{l}\text { Diversion } \\
\text { outflow }\end{array}$ & Seepage & $\begin{array}{ll} & \text { Tc } \\
\text { Bed } & \text { gr } \\
\text { material } & \text { se }\end{array}$ & $\begin{array}{l}\text { Topo- } \\
\text { graphic } \\
\text { setting } 3\end{array}$ & $\begin{array}{l}\text { Geologic } \\
\text { units }^{4}\end{array}$ & $\begin{array}{l}\text { Reach } \\
\text { length } \\
\text { (mi) }\end{array}$ & $\begin{array}{l}\text { Specific } \\
\text { seepage } \\
\left(\mathrm{ft}^{3} / \mathrm{s} / \mathrm{mi}\right)\end{array}$ \\
\hline Thomas & TMS-01 & 0.41 & - & - & - & Sand, cobbles & s UD & $\mathrm{Tv}$ & -- & - \\
\hline \multirow[t]{4}{*}{ Creek } & -02 & .59 & 0 & 0 & 0.18 & Gravel & UD & $\mathrm{Tv}$ & 2.04 & 0.09 \\
\hline & -03 & .03 & 0 & -0.21 & -.35 & Gravel & TR & Qal & 1.30 & -.27 \\
\hline & -04 & 1.2 & 1.9 & -.35 & -.4 & Gravel & TR & Qal & .35 & -1.1 \\
\hline & -05 & 2.2 & $>0$ (IRF) & 0 & - & Gravel, sand & VF & Qal & 1.13 & - \\
\hline Cottonwood & CTN-01 & 2.5 & -- & - & - & Gravel, clay & VF & Qal & - & - \\
\hline \multirow[t]{3}{*}{ Creek } & -02 & 2.8 & $>0$ (IRF) & 0 & - & Silt & VF & Qal & 1.23 & - \\
\hline & -03 & 2.1 & 0 & 0 & -.7 & Sil & VF & Qal & 1.45 & -.5 \\
\hline & -04 & 2.1 & 0 & 0 & 0.0 & Silt & VF & Qal & 1.40 & .0 \\
\hline North & NOC-01 & 53 & - & - & - & Basalt & TR & Tv & - & - \\
\hline \multirow[t]{2}{*}{ Canal } & -02 & 52 & 0 & 0 & -1 & Basalt & TR & $\mathrm{Tv}$ & 1.02 & -1 \\
\hline & -03 & 47 & 0 & 0 & -5 & Silt & TR & Qlo & 1.50 & -3 \\
\hline \multirow[t]{3}{*}{ Dry Creek } & DRY-01 & 20 & - & - & -- & Gravel & UD & $\mathrm{TV}$ & - & - \\
\hline & -02 & 1.0 & 0 & -16 & -2 & Cobbles & UD & Tv & 2.68 & -1 \\
\hline & -03 & .80 & .1 & 0 & -.3 & Gravel & TR & Qlo & 1.07 & -.3 \\
\hline Crane & CRN-01 & 1.8 & -- & - & - & Cobbles & UD & $\mathrm{T} \mathbf{v}$ & - & -- \\
\hline Creek & -02 & $<.03$ & 0 & -1.6 & -.2 & Cobbles & $\mathrm{AF}$ & Qal & .95 & -.2 \\
\hline Lassen & LSN-01 & 2.7 & - & - & - & Gravel & UD & QTb & - & - \\
\hline Creek & -02 & 2.0 & 0 & 0 & -.7 & Gravel & VF & Qal & 2.66 & -.3 \\
\hline
\end{tabular}

${ }^{1}$ Locations of measurement sites are shown on plate $1 \mathrm{a}$.

${ }^{2}$ Accuracy of measurements is 5 percent.

${ }^{3}$ Abbreviations: $\mathrm{UD}=$ upland draw; $\mathrm{TR}=$ terrace; $\mathrm{VF}=$ valley flat; $\mathrm{AF}=$ alluvial fan.

${ }^{4} \mathrm{Abbreviations:} \mathrm{Tv}=$ Tertiary volcanic rocks; QTb = Pliocene and Pleistocene basalts; Qal = younger alluvium; Qlo = older alluvium. 
selected to represent a wide variety of stream-aquifer environments, ranging from high-gradient upland streams bedded in volcanic tuffs or basalts to low-gradient valley-flat reaches bedded in silty alluvium. Flows in Cottonwood Creek, Dry Creek, and the North Canal are maintained during the early summer months from storage in upstream reservoirs.

Nearly all of the reaches measured in August 1986 were losing water to the ground-water system. Exceptions were the uppermost reach of Thomas Creek (TMS-01 to TMS-02 on plate 1a), the lowermost reach of Cottonwood Creek (CTN-03 to CTN-04), and reaches on Thomas and Cottonwood Creeks receiving unmeasureable spring flow and irrigation return flow.

Thomas Creek gained nearly 0.2 cubic feet per second $\left(\mathrm{ft}^{3} / \mathrm{s}\right)$ within the last 2 -mile reach (TMS- 01 to TMS-02) before it entered the valley; this gain suggests that its $0.6 \mathrm{ft} 3 / \mathrm{s}$ discharge at this point (TMS-02) was mostly--if not entirely--baseflow, since the snowpack was gone by mid-August and there was no recent precipitation immediately prior to measurement. No loss was shown between sites CTN-03 and CTN-04 on lower Cottonwood Creek, suggesting a transition from losing to gaining conditions. As it nears Goose Lake, Cottonwood Creek probably enters the ground-water discharge area of the basin and receives an increasingly important baseflow component.

Losses measured in August 1986 ranged from 0.2 to $1\left(\mathrm{ft}^{3} / \mathrm{s}\right) / \mathrm{mi}$ on stream reaches (not including the North Canal). The mean rate was $0.5(\mathrm{ft} / \mathrm{s}) / \mathrm{mi}$. These conditions no doubt vary considerably during the year, as stream-stage and ground-water levels fluctuate in response to precipitation, runoff, pumping, and ET. During periods of peak runoff, stream losses are much greater and large volumes of runoff enter bank storage until the streams have passed their peak stage. When the stage starts to fall, the direction of flow reverses and ground water sustains streamflow at elevated levels for a time from accumulated bank storage. After bank storage is drained, the direction of flow again reverses and streamflow infiltrates to the water table.

Streams that originate in the Warner Mountains are for the most part intermittent. During storms and periods of rapid snowmelt, streamflow debouches along the valley perimeter and moves down the alluvial fans toward Goose Lake. Under natural conditions, much of the streamflow infiltrated the permeable surficial deposits on the fans, percolating through the alluvial deposits until it reached the water table. Since many of these streams are now utilized for irrigation, a large percentage of runoff is lost to ET.

An average of 36,000 acre-ft/yr of irrigation water was diverted from storage in Drews and Cottonwood Reservoirs between 1981 and 1985. According to records of the Lakeview Water Users Association, an average of 9,000 acre-ft (25 percent) are lost each year from the unlined North, Middle, and East Canals (Holly Canon, Manager, written commun., December 1985). The August 1986 seepage measurement on a 2.5 -mile segment of the North Canal (in section 13, T.39S., R.18E.) showed seepage rates of 1 and $3(\mathrm{ft} 3 / \mathrm{s}) / \mathrm{mi}$ on the two reaches. The upper reach traverses a small exposure of basalt (NOC-01 to NOC-02) and had the lower infiltration rate. The lower reach (NOC-02 to NOC-03) overlies more permeable lake terrace deposits and loses considerably more of its flow per mile.

The overall rate of leakage from streams and unlined canals in the basin could not be estimated from data available during this study. The ground-water model analysis (discussed in a later section) included tests of model sensitivity to uncertainty in estimated recharge in order to determine if additional data would be needed to quantify recharge from stream and canal leakage.

\section{Ground-water Movement}

Ground-water movement is generally from the surrounding uplands and valley margins toward Goose Lake. This pattern describes ground-water movement in both shallow, unconfined zones (fig. 14) and deeper, confined zones (fig. 15). Water levels used to construct the contours shown in figures 14 and 15 were measured by Trauger (1950) between 1948 and 1949 in Oregon and by CDWR (1963) during the spring of 1960 in California. Although the measurements were made 12 years apart, it is reasonable to assume that 


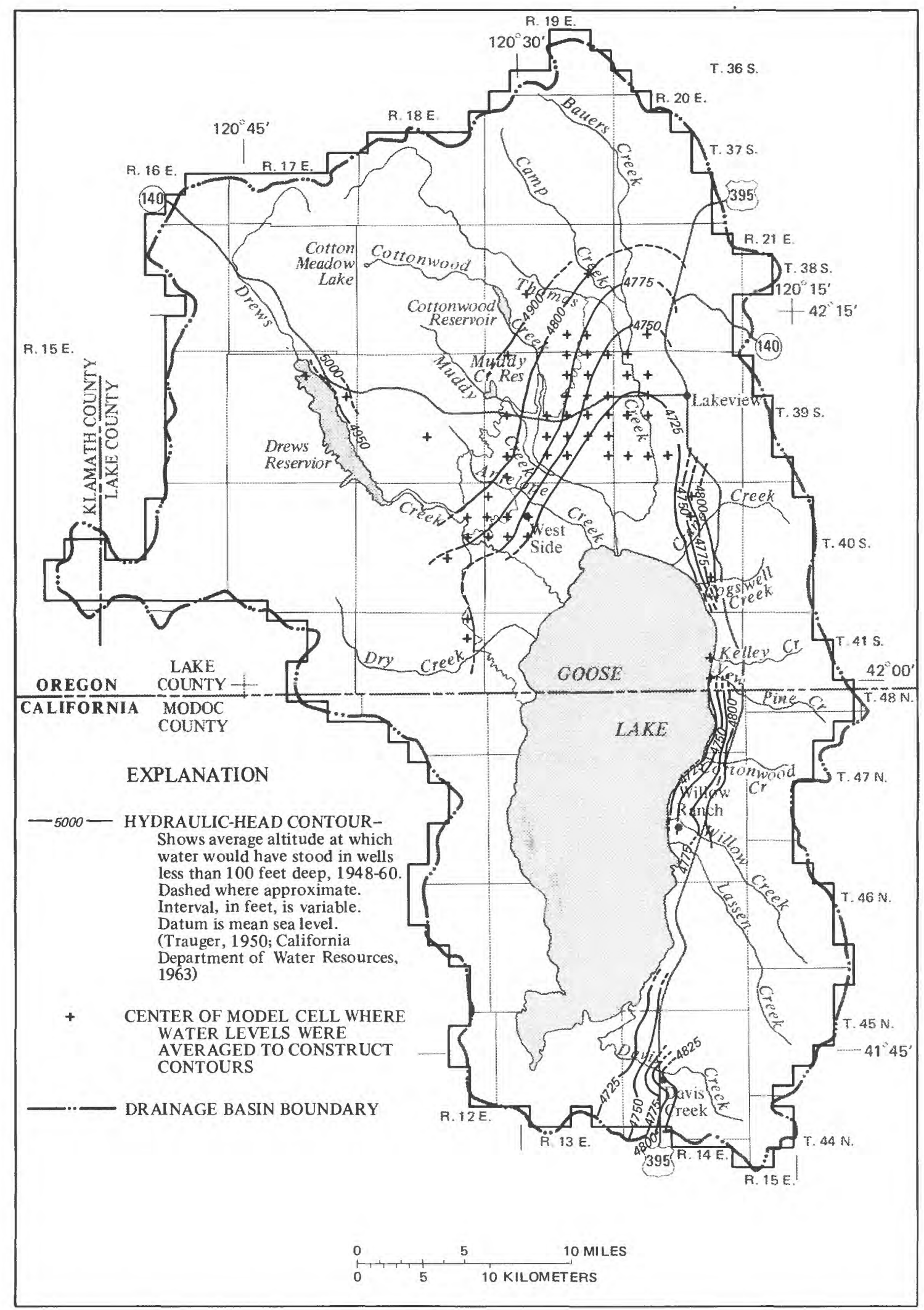

Figure 14.--Average altitude of the hydraulic head in wells less than 100 feet deep, 1948-60. 


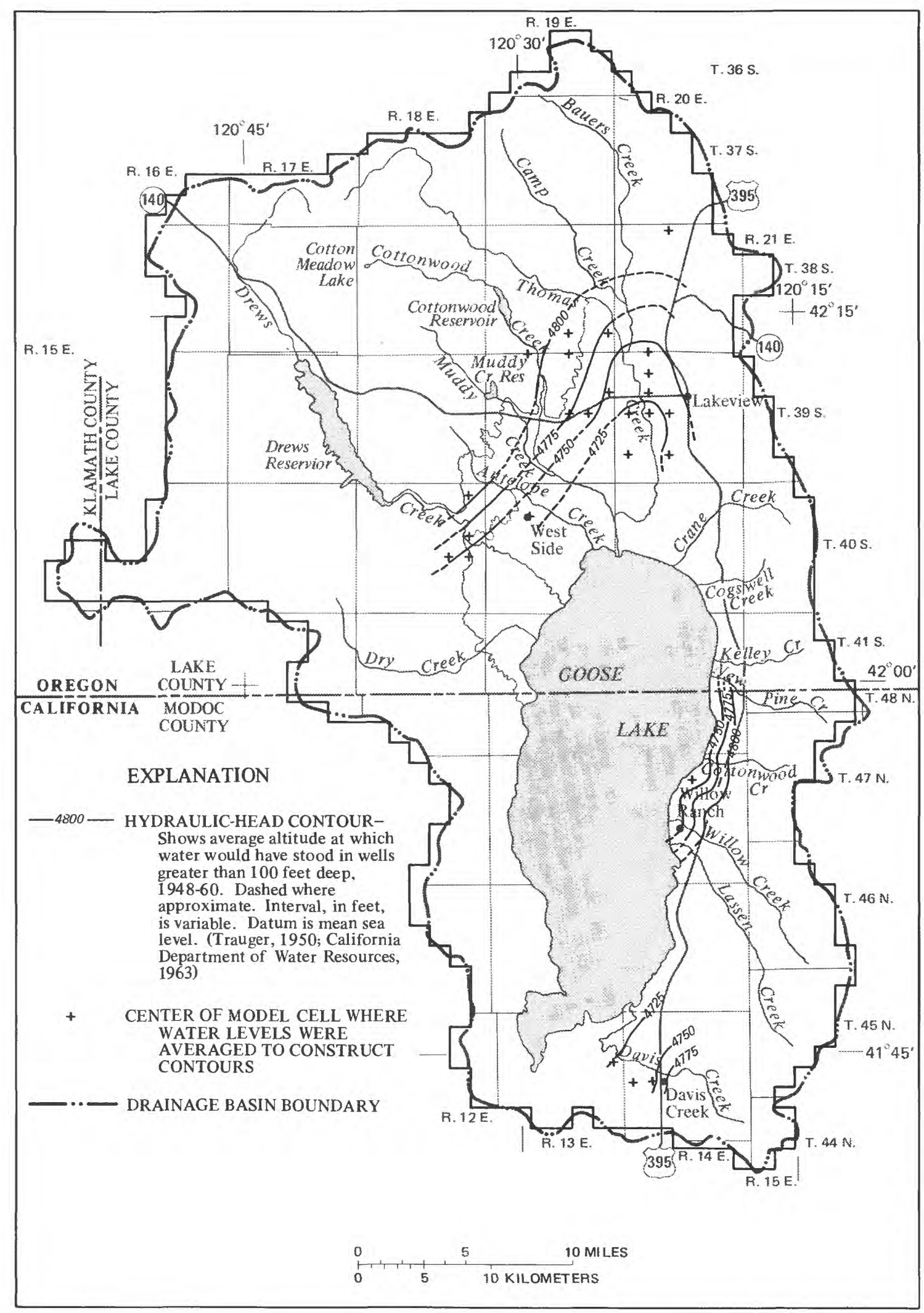

Figure 15.--Average altitude of the hydraulic head in wells more than 100 feet deep, 1948-60. 
water levels measured during the two periods reflect similar conditions of recharge and discharge. Hydrographs of wells in Oregon for the period 1945-53 (published by Trauger, 1950, pls. 11-26) show no long-term water-level changes. A well (45N/14E-17CD) near Davis Creek, California, has been monitored since 1956 and showed no upward or downward trend in mean annual water level between 1956 and 1960 (California Department of Water Resources, 1982, fig. 11). Although there is no continuity or overlap in the water-level records for the 1953-56 period, ground-water withdrawals and precipitation were stable and it is thus assumed that ground-water levels were also stable.

Within the uppermost few hundred feet of basin-fill deposits hydraulic gradients toward Goose Lake are as much as $32 \mathrm{ft} / \mathrm{mi}$ (feet per mile) parallel to east-west flow paths and $11 \mathrm{ft} / \mathrm{mi}$ in the north-south flow paths. Topography plays a large role in this contrast; however, the distribution of high (coarse-grained) and low (fine-grained) permeability basin-fill deposits (figs. 6 and 7) also controls hydraulic lateral gradients.

The south end of the drainage basin is formed by a low, east-west topographic divide that extends from about 3.5 miles west to 1.5 miles east of the point where Highway 395 exits the basin. During the spring of 1960 , the principal direction of ground-water movement in this area was northwesterly toward Goose Lake. The CDWR $(1963$, p. 26) reported, however, that water levels in a few wells penetrating Pleistocene basalts near section 18, T.45N., R.14E., showed a hydraulic gradient toward the southwest. This phenomena was not mentioned in a more recent study by the CDWR (1982) and could not be verified from data collected for this investigation. Water-level data for this area collected in the spring of 1981 (California Department of Water Resources, 1982, pl. 1-C) show that, within the shallow aquifers, the topographic boundary marks the location of the ground-water divide between Goose Lake and Alturas basins. Seasonal pumping for irrigation may reduce outflow or induce inflow across this boundary, but this condition cannot be documented by existing data.

The magnitudes of vertical hydraulic gradients in the basin, both natural and those induced by pumping, are difficult to establish because of the lack of (1) shallow and deep observation-well pairs, (2) accurate landsurface elevations at wells, and (3) synoptic water-level measurements. The existence of upward vertical hydraulic gradients in the ground-water discharge area underlying and surrounding Goose Lake is substantiated by comparisons of mean heads for wells of equal depth within small areas. Comparison of mean heads in wells north of the lake shows that, on the valley floor, heads in shallow wells may be 10 to 15 feet less than heads in wells with depths of 100 feet or more. Near Willow Ranch, hydraulic heads in confined aquifers are up to 30 feet lower than the water table on the upper part of the alluvial fans. At the edge of the lake, the vertical hydraulic gradient is upward, with confined hydraulic heads as much as 20 feet above the water table (California Department of Water Resources, 1963, p. 85).

Hydraulic gradients and ground-water movement are no doubt considerably more complex within the volcanic upland areas than they are in the basin-fill deposits. Although the volcanic uplands and the basinfill deposits together comprise a single flow system, the hilly topography in the uplands produces numerous subsystems. Each subsystem has its own recharge and discharge areas, but contributes to the regional flow toward the basin-fill deposits. Regionally, hydraulic gradients within the uplands are assumed to be toward the center of the basin; within subsystems, gradients would generally be toward the local discharge area, such as a lake, stream, or wet meadow. Drews Reservoir is probably the largest discharge area within the uplands, and some wells in the area show hydraulic gradients toward the reservoir (fig. 14).

\section{Discharge}

Ground-water discharge from the Goose Lake basin is primarily by pumping from wells, evaporation from soils and transpiration by plants (evapotranspiration or ET), and seepage to lakes, reservoirs and streams. There is also a potential for subsurface outflow. These processes and their impact on the groundwater flow system are discussed in the following sections. 


\section{Water Pumped From Wells}

Most ground-water pumpage in the basin is used for irrigation of alfalfa and forage crops. Other groundwater users include the City of Lakeview, local industry, and individual well owners. Table 5 summarizes permitted, not actual, ground-water withdrawals in Oregon as of 1986.

Table 5.--Permitted ground-water withdrawals in the Oregon portion of the Goose Lake basin, 1986

\begin{tabular}{lcc}
\hline \multicolumn{1}{c}{ Use } & $\begin{array}{c}\text { Permitted } \\
\text { withdrawal } \\
\text { Acre-feet/year) }\end{array}$ & $\begin{array}{c}\text { Percent of total } \\
\text { permitted } \\
\text { withdrawals }\end{array}$ \\
\hline Irrigation & 59,400 & \\
Municipal & 2,400 & 94 \\
Industrial & 600 & 4 \\
Utilities ${ }^{1}$ & 500 & 1 \\
\hline
\end{tabular}

1 Withdrawal permit for geothermal power generation.

Ground-water pumpage for irrigation in 1985 was estimated using the power-consumption method. Power consumed by a well-pump is directly related to pump efficiency, total lift, discharge pressure head, and the volume of water pumped. When pumpage is the unknown, this relation is expressed mathematically as (Frenzel, 1985, p. 221):

where

$$
Q=\frac{k w h}{E\left[\left(H_{0}-H_{p}\right)+p_{h}\right]}
$$

Q = total volume of water pumped, in acre-feet;

kwh = power consumed, in kilowatt-hours;

$\mathrm{E} \quad=$ pumping efficiency factor, in kilowatt-hours per acre-feet per feet of lift of water pumped;

$\left(\mathrm{H}_{\mathrm{O}}-\mathrm{H}_{\mathrm{p}}\right)=$ lift from the pumping level, $\mathrm{h}_{\mathrm{p}}$, to land surface, $\mathrm{H}_{\mathrm{O}}$, in feet; and

$\mathrm{p}_{\mathrm{h}} \quad=$ discharge pressure head at land surface, in feet of water;

Monthly power-consumption totals for May through October of 1985 were provided by the local power company for the 80 irrigation wells operated that year.

Pumping lift $\left(\mathrm{H}_{\mathrm{O}}-\mathrm{H}_{\mathrm{p}}\right)$ was measured in 21 wells; the mean pumping lift, 90 feet, was used to compute pumpage at wells where lift data were not available. Static lifts, $\mathrm{H}_{\mathrm{S}}$, were available for some wells, so the mean difference between static and pumping lifts $\left(\mathrm{H}_{\mathrm{p}}-\mathrm{H}_{\mathrm{S}}\right)$ was computed for the 21 measured wells. The mean difference, 55 feet, was then added to static lifts at wells where $\mathrm{H}_{\mathrm{p}}$ was unknown to estimate pumping lift. Pumping lifts in the basin are relatively uniform and the use of a basin-wide average for unmeasured wells probably does not introduce significant error. 
Discharge pressure head, $P_{h}$, was measured at 17 wells discharging to sprinkler systems by reading a pressure gage connected to the discharge pipe. Pressures showed no relation to the type of sprinkler system, had a range of 115 to 180 feet of water, and a mean of 150 feet of water (65 pounds per square inch).

The pumping efficiency factor, $\mathrm{E}$, varies depending on the age and condition of the pump. Pumping plant efficiency, $F$, can be determined in the field by monitoring the power consumed to pump a known quantity of water. Four such tests conducted in the Lakeview area by the U.S. Soil Conservation Service (SCS) yielded plant efficiencies of 43, 55, 69, and 70 percent (William Schrader, U.S. Soil Conservation Service, written commun., May 1986). The mean efficiency, 59 percent, was used in this study as a regional average to compute pumpage. The pumping efficiency factor, $\mathrm{E}$, is related to plant efficiency, $F$, by the equation:

$$
E=K\left(\frac{100}{F}\right)
$$

where $\mathrm{K}$ is equal to 1.02 , the number of kilowatt-hours required by a 100-percent efficient pump to lift 1 acre-foot of water 1 foot (Diamond and Williamson, 1983, p. 6). The pumping efficiency factor used for Goose Lake basin was therefore 1.73 kilowatt-hours per acre-foot per foot of lift. This value compares well with those estimated for other studies using many more on-site plant efficiency tests. For example, Bigelow and others (1984, sheet 1) estimated a pump-efficiency factor of 1.69 from 72 tests on the Snake River plain of Idaho and eastern Oregon, and 300 plant efficiency tests conducted on the Columbia Plateau in eastern Washington had a mean of 60 percent, $E=1.70$ (P. C. Van Metre, U.S. Geological Survey, Tacoma, Washington, written commun., February, 1986).

Estimated ground-water use for irrigation within the Goose Lake basin in 1985 was 17,200 acre-ft. Twenty-seven percent (4,700 acre-ft) of this total was withdrawn in Califomia, mostly from wells near Davis Creek. Most of the irrigation pumpage in Oregon occurs on the west side of the valley, although some pumping is concentrated in the northeastern part of the basin. plate $1 \mathrm{~b}$ shows the areal distribution of irrigation pumping in 1985. Monthly irrigation pumping rates peak in July and August (fig. 16) when surface-water supplies have been exhausted and supplemental irrigation is required.

It was not within the scope of this study to reconstruct a historical record of ground-water use in the basin; however, figure 17 shows electric power consumption for irrigation from 1975 to 1986 . Note that annual power consumption data used to construct figure 17 is for Oregon only, but includes power consumed by ditch pumps. As shown in figure 16, ditch pumps account for only a small part of total consumption in the Goose Lake basin. If the proportion of power consumption by ditch pumps has remained relatively constant since 1975, the trends shown in figure 17 would be indicative of changes in ground-water withdrawals for irrigation during this period. This also assumes that average pumping lift, pressure head, and pump efficiency remained constant. On the basis of these assumptions, ground-water withdrawals peaked in 1981, declined rapidly through 1983, and continued to decline--although at a lower rate--through 1986.

There are several potential sources of error in the estimate of pumpage derived in this study. The most important sources of error probably stem from inaccuracies in estimates of discharge pressure head and pumping lift. If field measurements of discharge pressure head are not available, uncertainty in pressure head can be greatly reduced if the irrigation method at the well is known. Irrigation method was determined by site visits and inspection of aerial photographs and water-rights maps. Wells for which irrigation method was unknown were assumed to discharge to sprinkler systems and have a pressure head of 150 feet of water. Under this assumption, pumpage would be significantly underestimated at wells that pump into ponds or ditches against a discharge pressure head of zero. The irrigation method was not known at 42 of the 80 wells.

Listed in table 6 are the results of several pumpage calculations where the basin-wide default values of pumping-lift, discharge pressure head, and pumping efficiency factor were varied to determine the potential magnitude of errors produced by uncertainty in these parameters. 


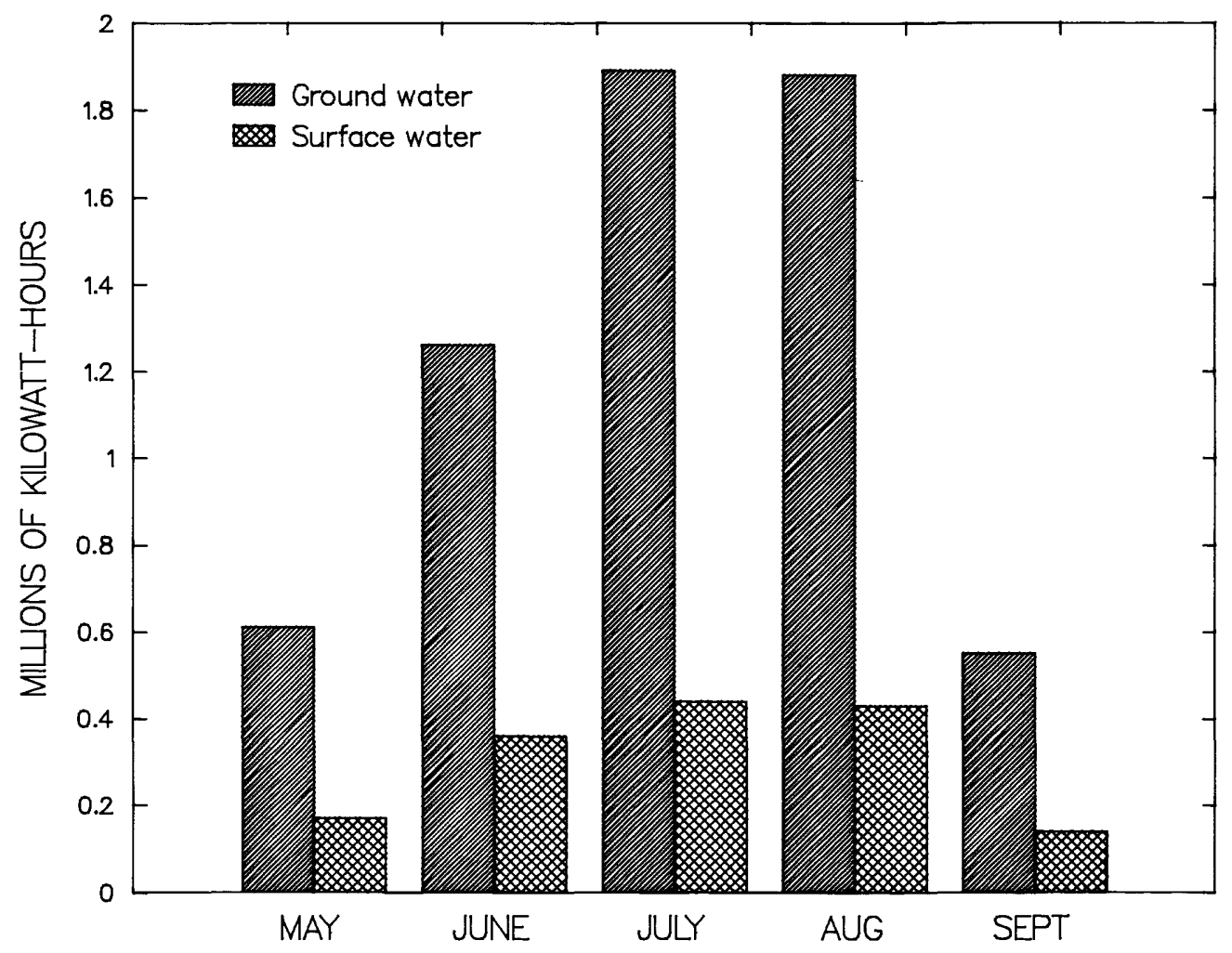

Figure 16.--Monthly electric power usage for irrigation (Oregon only), May to September 1985.

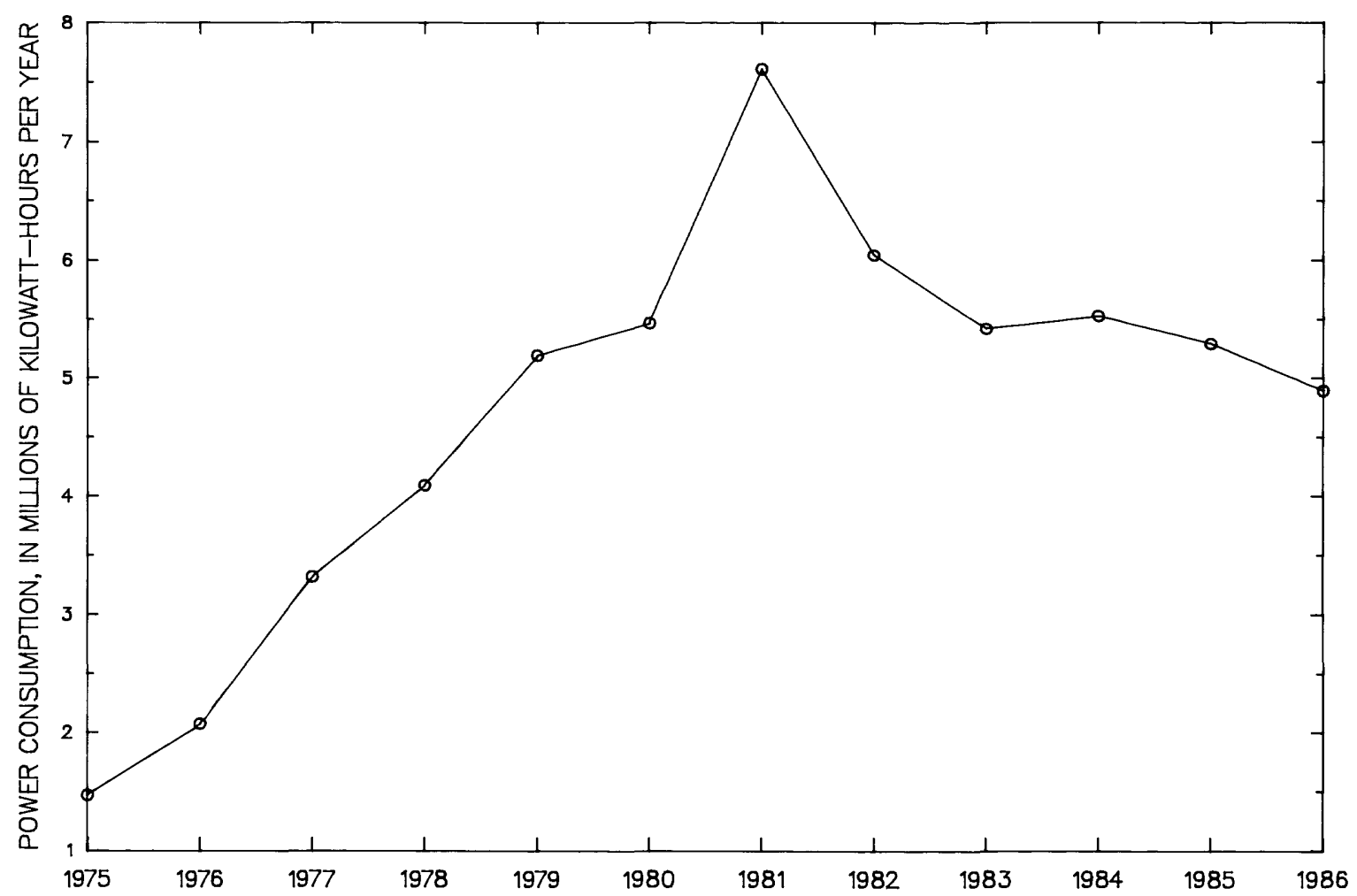

Figure 17.--Annual power consumption by irrigation pumps in Oregon, 1975-1986. 
Table 6.--Sensitivity of 1985 Goose Lake basin pumpage estimates to uncertainties in pumping lift, discharge pressure head, and pumping efficiency factor

[Numbers in parentheses are changed from best estimates]

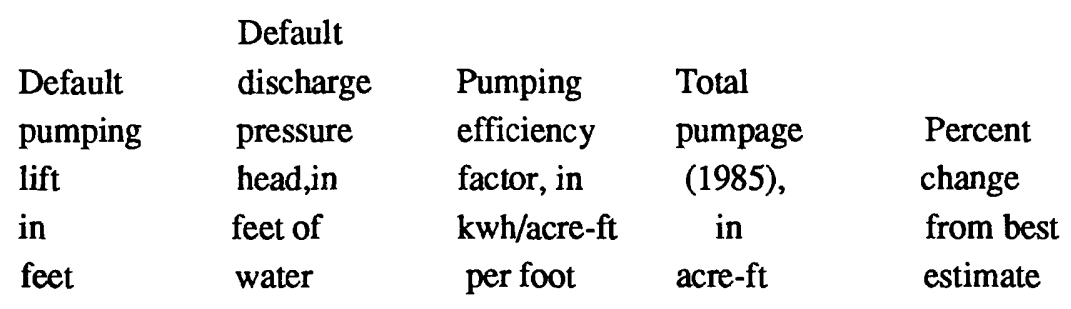

\begin{tabular}{lccccc}
$\begin{array}{l}\text { Best } \\
\text { estimate }\end{array}$ & 90 & 150 & 1.73 & 17,200 & 0 \\
\hline & $(135)$ & 150 & 1.73 & 14,300 & 17 \\
& $(45)$ & 150 & 1.73 & 22,700 & +32 \\
90 & $(0)$ & 1.73 & 27,700 & +61 \\
90 & 150 & $(2.55)^{1}$ & 11,500 & -33 \\
& 150 & $(1.46)^{2}$ & 20,000 & +16 \\
\hline
\end{tabular}

1 Average pumping plant efficiency of 40 percent.

2 Average pumping plant efficiency of 80 percent.

Results show that if all 42 of the wells where irrigation method is not known discharged to ponds or ditches (for example, discharge pressure head equals zero), 1985 pumpage would be underestimated by 61 percent. Calculations in table 6 also show that if mean pumping lift were 50 percent greater ( 135 feet) or less ( 45 feet) than the estimate of 90 feet, actual pumpage would be 17 percent less than or 32 percent greater than estimated pumpage. Also, if the mean pumping-efficiency factor were 33 percent greater $(2.55)$ or less (1.46), the estimate of 1.73 actual pumpage would be 33 percent less than or 16 percent greater than estimated pumpage.

Errors in discharge pressure head, or indirectly, lack of knowledge of the irrigation method used at wells, appear to be the greatest potential source of errors in pumpage estimates for the Goose Lake basin.

Finally, power company records did not indicate whether the source of water to pumps was ground water or surface water. Resolution of the source of water to pumps was achieved by several methods: (1) field inspection of pumps; (2) cross-referencing of power company account numbers, customer names, and pump locations with well locations and owner names; and (3) consultation with the State Watermaster and the manager of the local irrigation district. The horsepower of pumps was available from the power company and proved to be a useful indicator of ditch pumps (low horsepower) versus well pumps. Overall, overestimation of pumpage due to inclusion of surface-water pumps is not considered an important source of error.

\section{Evapotranspiration}

Ground water is lost to the atmosphere by evaporation from bare soils and by transpiration from the leaves of phreatophytes (plants whose roots draw water from the saturated zone). 
The rate of steady evaporation from bare soil diminishes rapidly with increasing depth to the water table and is negligible for most soils if the water table is more than 10 feet below land surface (Brutsaert, 1982, p. 236). Transpiration rates are dependent on the type and density of phreatophytes, climatic conditions, quality of ground water, and depth to water (Robinson, 1958, p. 16). It is important to note that the evaporation and transpiration considered here are from the saturated zone and represent ground-water discharge in addition to that by evaporation and transpiration of moisture stored in the unsaturated zone. ET of moisture from the unsaturated zone was discussed in the section "Deep Percolation of Precipitation and Irrigation Water."

In the Goose Lake basin, the water table is within 10 feet of land surface under large tracts of the valley floor. Lowland areas adjacent to streams, such as the lower Thomas Creek drainage, become completely inundated by spring runoff; in these areas the water table is probably always within a few feet of land surface. A variety of phreatophytes are found in the basin (U.S. Department of Agriculture, 1978), the most common include willow (salix), aspen (populus tremuloides aurea), cottonwood (populus), juniper (juniperus scopulorum), big greasewood (sarcobatus vermiculatus), rabbitbrush (chrysothamnus pumilus), giant wildrye (Elymus condensatus), saltgrass (Distichlis stricta), and alfalfa (Medicago sativa).

The total area covered, density, and consumptive-use requirements of phreatophytes in Goose Lake basin are unknown. The potential evapotranspiration (PET) in the basin, computed by the Jensen-Haise method (Bauer and Vaccaro, 1987), for the period 1954-1980, is 42 inches per year.

Conditions exist that suggest there is a large quantity of ground-water discharged annually by ET, yet it was not within the scope of this investigation to perform a detailed, quantitative study of discharge by this process. Discharge by ET was simulated, however, by a ground-water flow model of the basin, which is discussed in a later section. The model was used to estimate reductions of ET that might occur if groundwater withdrawals lower the water table.

\section{Seepage to Goose Lake and Streams}

Ground-water discharge occurs if the water table intercepts land-surface, such as at a stream channel or lakebed, and the hydraulic head in the aquifer is greater than the stage in the lake or stream. Streams in the basin receive ground-water discharge in both the upland ground-water subsystems and in the discharge area of the valley floor. Upland reservoirs and lakes (Drews, Cottonwood, and others) are also subsystem discharge areas. Goose Lake lies at the lowest point in the basin and represents the focal point of discharge for the ground-water system.

Several previous studies have addressed the topic of ground-water discharge to Goose Lake and estimated water budgets for the lake. The water budgets developed by these studies are compared in table 7 .

Ground-water discharge to Goose Lake was estimated for this study on the basis of surface-water runoff and potential evapotranspiration estimates derived for and from the DPM-GWR model described in the section "Deep Percolation of Precipitation and Irrigation Water." Mean annual surface-water inflow to the lake, 200,000 acre-ft/yr, was adjusted for irrigation diversions (130,000 acre-ft/yr) and return flow $(30,000$ acre-ft/yr), resulting in an estimated surface-water contribution of 100,000 acre-ft/yr. Evaporation from the lake surface was assumed to occur at the estimated potential rate of $42 \mathrm{in} / \mathrm{yr}$. This rate is in close agreement with those used by Phillips and Van Denburgh (1971) and Nebert (1985). Precipitation on the lake surface is approximately $12 \mathrm{in} / \mathrm{yr}$. Goose Lake covers 92,000 acres at a stage of 4,700 feet above sea level (Daum, 1966, table 6); at this stage, Goose Lake loses 322,000 acre-ft/yr to evaporation and gains 92,000 acre-ft/yr from precipitation. Thus, evaporation losses exceed total inflow by 130,000 acre-ft/yr--the estimated groundwater discharge to the lake.

Waring's (1908) seepage estimate of 144,000 acre-ft/yr is similar to that of this study, but was made for a period prior to significant irrigation diversions, and the closeness of the estimate stems from Waring's underestimation of surface-water runoff. 
Table 7.--Summary of water-budget estimates for Goose Lake by previous studies and this study

Values are in acre-feet per year unless otherwise noted. Computation notes: Stream inflow (c) equals basin streamflow (a) minus diversions (b); net outflow (g) equals precipitation (e) minus evaporation (d) times area (f); ground-water seepage to lake (h) equals net outflow (g) minus stream inflow (c).

(a)

(b)

(c)

(d)

(e)

(f)

(g)

(h)

Net Ground-

Basin

stream

Study

flow

Diversions

Stream

Evapo-

Precipi-

outflow

water

tation

Area

(acre-

seepage

(in/yr)

(acres)

$\mathrm{ft} / \mathrm{yr}$ )

to lake

\section{Waring}

(1908)

120,000

$0 \quad 120,000$

40

Daum

(1966)

204,000

136,000

68,000

51

Phillips

and Van

Denburgh

(1971)

250,000

85,000

165,000

42

14

171,00

165,000

0

Nebert

(1985)

$$
210,000
$$

25,000

185,000

41.2

$13.5 \quad 86,200$

199,000

214,000

study

200,000

3100,000

100,000

42

$12 \quad 92,000$

230,000

130,000

\footnotetext{
${ }^{1}$ Area inferred from published evaporation total and rates. The published area (Daum, 1966) for the stage used by Philips and

Van Denburgh (4,697 feet above sea level) is 78,200 acres.
}

2Nebert (1985, fig. 8) assumed ground-water inflow to be zero.

${ }^{3}$ Actual diversions are estimated to be 130,000 acre-ft/yr, return-flow of 30,000 acre-ft/yr was assumed for this calculation.

Daum's (1966) maximum estimated rate of ground-water inflow $(244,000$ acre-ft/yr) was based on lake evaporation of $51 \mathrm{in} / \mathrm{yr}$ (considerably higher than that indicated by other studies). The minimum rates of inflow, suggested by Phillips and Van Denburgh (1971) and Nebert (1985), are essentially zero, although Nebert's budget shows a residual of 14,000 acre- $\mathrm{ft} / \mathrm{yr}$. The discrepency between the estimates of these studies and the present investigation can be attributed primarily to the amount of streamflow estimated to reach the lake and secondarily to the assumed area of the lake; the net rates of exchange between the lake and atmosphere (evaporation minus precipitation) vary by only 2.0 to $2.3 \mathrm{in} / \mathrm{yr}$.

Uncertainties in estimates of the surface-water inflow to the lake and the surface area of the lake obviously do not allow a conclusive estimate of the magnitude of ground-water discharge to the lake. Hydraulic evidence, however, also supports the occurrence of discharge to the lake; specifically, lateral hydraulic gradients show that ground-water movement toward the lake and artesian wells near the edge of the lake are evidence of upward hydraulic gradients beneath the lake (Trauger, 1950; California Department of Water Resources, 1963). Also, Harding (1965, p. 27 and 47) reported numerous springs and seeps that have been observed when the lake receded or went dry. 
Flow in perennial streams in the basin, such as Davis, Cottonwood, and Thomas Creeks, is sustained during summer and fall by ground-water discharge (baseflow). These streams receive ground-water seepage as they cross discharge areas of upland ground-water subsystems. Stream reaches near Goose Lake probably also receive seepage as they enter the ground-water discharge area surrounding the lake. Ground-water discharge by seepage to streams could not be estimated from data available for this study. The mean monthly minimum of total streamflow in the basin was used as an approximation of monthly seepage to streams (baseflow) in the process of estimating recharge from deep percolation of precipitation and irrigation (see Appendix I). The annual seepage to streams in the basin estimated in this way averaged approximately 100,000 acre-ft/yr from 1954 to 1980 . Total daily streamflow in the basin was synthesized from the long-term records of only one inbasin gaging station (Cottonwood Creek near Lakeview); this estimate should thus be considered only an indicator of the magnitude of maximum ground-water discharge by seepage to streams.

Natural ground-water discharge to lakes and streams in the basin was investigated by a numerical simulation analysis of the ground-water flow system. In the "Model Analysis" section, simulated discharge rates to lakes and streams and how they may be affected by data uncertainty and ground-water pumping are discussed.

\section{Subsurface Outflow}

Hydraulic and geologic data suggest that subsurface outflow from the basin near Davis Creek is possible; elsewhere in the basin, geologic facies and structure are not compatible with such a conceptual model. Hydraulic-head and possibly geochemical data would be necessary to confirm this assumption.

The drainage divide south of the town of Davis Creek is underlain by interbedded basin-fill deposits and Pleistocene basalts. Spring 1960 water levels in wells measured by CDWR (1966, pls. 4 and 5) showed that, within the upper 400 feet of deposits, the ground-water divide coincided with the drainage divide. Pliocene and Pleistocene basalts outcrop northeast of Davis Creek (pl. 1a) and are interbedded with basin-fill deposits underlying Davis Creek at depths greater than 400 feet. The extent of the buried Pliocene and Pleistocene basalts is unknown; however, several wells that are apparently completed within them were also measured in spring 1960. Heads in these wells showed a hydraulic gradient to the southwest, perpendicular to the gradient in the shallower deposits (California Department of Water Resources, 1963, p. 88). Additional water-level data are needed to determine whether subsurface outflow actually occurs in this area. Evidence of large quantities of subsurface outflow to the south, such as anomalously large springs or baseflow in the upper North Fork Pit River, have not been observed or reported by previous investigations.

\section{Water-level Changes}

Water levels in observation wells declined by as much as 13 feet between 1972 and 1981; the average rate of decline was approximately 1 foot per year during this period. Representative hydrographs for longterm observation wells in the basin is shown in figure 18; locations of those wells are shown on plate 1a. The maximum rate of decline, nearly 3 feet per year, occurred between 1974 and 1981 at well 39S/20E-9AAD (fig. 18). The period of water-level declines closely followed the onset of larger scale pumping in the basin. Insufficient long-term water-level records are available to determine the areal or vertical extent and magnitude of these declines.

Water levels have recovered since 1982 at rates equal to their previous rates of decline. As of 1985 , however, the water levels in most observation wells had not regained their pre-1972 altitudes. The recovery is due to the reduction in pumping that has occurred and, in shallow wells, to above-normal precipitation for the period 1981-1984.

Seasonal water-level fluctuations prior to 1972 ranged from at least 3 to 6 feet, depending on depth and proximity to other pumping wells. Marked increases in seasonal water-level fluctuations are evident after 1972 (fig. 18), when higher pumping rates resulted in irrigation season water levels at least 10 to 20 feet below peak levels in early spring. Seasonal water-level changes are generally less in shallow aquifers. Ranges of 2 to 5 feet are common, with peaks occurring between January and April in response to heavy precipitation and spring runoff (U.S. Department of Energy, 1985). 

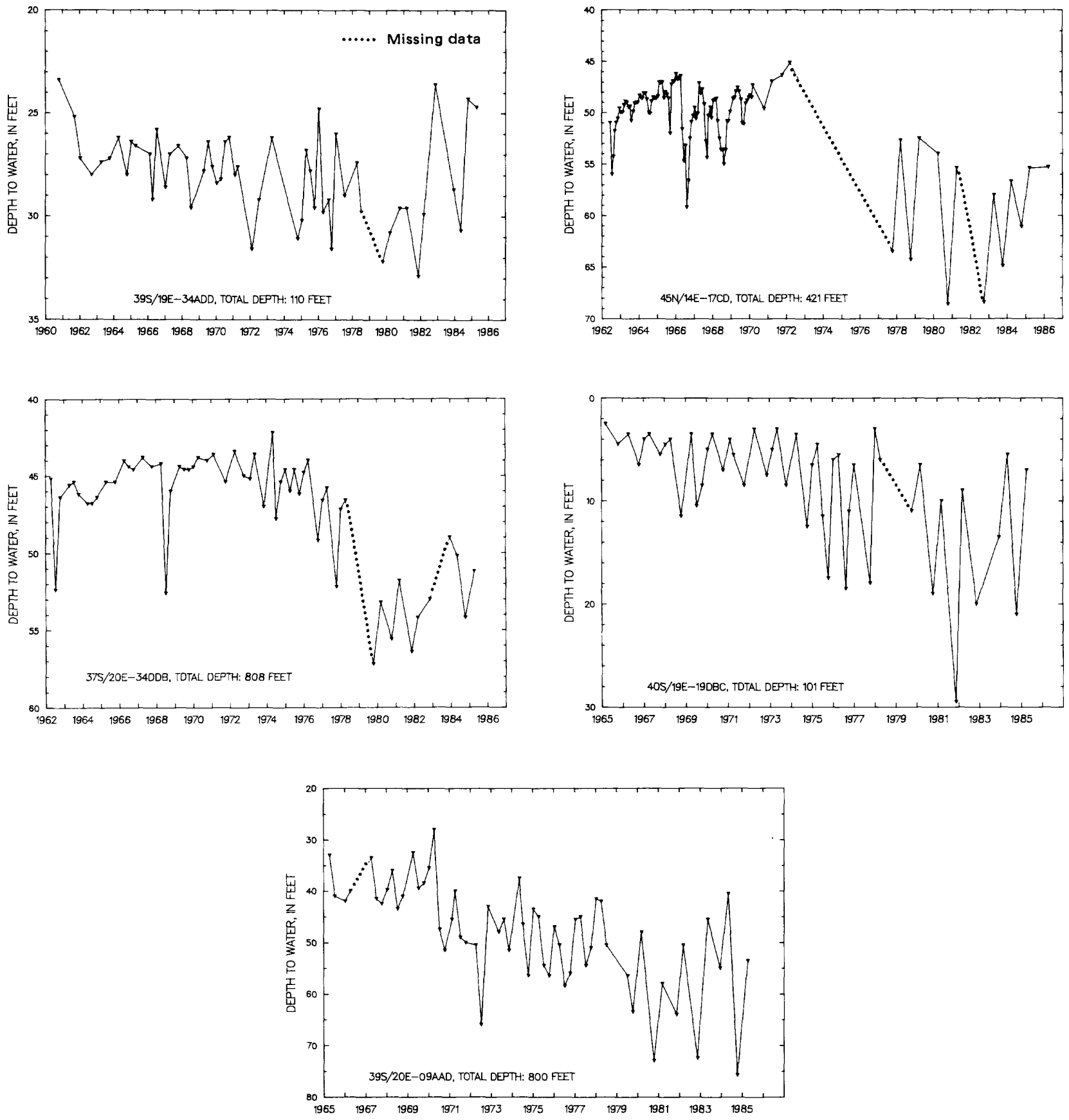

Figure 18.--Hydrographs showing water-level changes at selected wells.

38 


\section{NUMERICAL MODEL ANALYSIS OF THE GROUND-WATER FLOW SYSTEM}

A computer model of ground-water flow in the Goose Lake basin was constructed for the purposes of testing the conceptual model(s) of the flow system and determining the sensitivity of model results to uncertainty in data available for its construction. To be considered a useful tool in managing future groundwater development in the basin, the model should fulfill the following conditions:

(1) The model should be based on a valid concept of the system and must reproduce that system reasonably well.

(2) The error in model results caused by uncertainties in input parameters should be considered acceptable. The definition of "acceptable error" depends largely on the specific question being addressed with the model.

The final purpose of the model analysis was to guide future data collection and monitoring in the basin. Data found to be lacking or unreliable in the sensitivity analysis would be given high priority for future collection efforts.

\section{Approach}

The analysis made using the flow model considered ground-water conditions both before and after significant ground-water development in the basin. The period prior to significant ground-water development is defined as pre-1970, when most irrigation water used in the basin was diverted from streams. Since streamflow had been fully utilized for this purpose since the early 1900's, it was assumed that the effects of irrigation on water levels had subsided and that, despite seasonal fluctuations, average annual water levels were stable. After 1970, increased pumping for, and recharge from, irrigation disturbed that equilibrium and water levels changed in response to the new stresses on the system. In the following discussions, the terms "pre-" and "post-development" will refer to periods before and after significant ground-water development. Surface-water development is assumed for both periods.

The sensitivity analyses were conducted by first constructing a baseline model for pre-development conditions, based on best estimates of model parameters. Model parameters and some boundary conditions then were varied, and the effect on the model-calculated water levels and discharge was measured. Water levels measured by Trauger (1950) and CDWR (1963) during the pre-development period were compared with model-calculated water levels. The mean deviation of calculated from observed water levels was used to evaluate the baseline model and to measure the sensitivity of model response to changes in the various parameters. Calculated components of natural discharge (ET, seepage to lakes and streams) were also used to evaluate and measure the sensitivity of the pre-development model.

The second step in the analysis was to impose a stress on the pre-development model. A postdevelopment baseline model was constructed in this way by taking the original baseline model parameters, adding 1985 pumping stress, and substituting post-development recharge rates. Transient effects of changes in aquifer storage were ignored in this step. The calculated water levels represented levels that would occur when the system had reached a new equilibrium for the given pumping and recharge. The response of the flow system to these stresses was measured by calculating the mean computed water-level changes at cells containing irrigation wells for 1985 . The sensitivity of the post-development model to pumping and to uncertainties in parameters was assessed in the same manner as for the pre-development model. Calculated mean water-level changes and natural discharge rates were used to gage the sensitivity of the model.

A "worst case" post-development scenario was simulated by selecting the minimum reasonable values of aquifer parameters such that the predicted drawdown would be the maximum expected for a given pumping rate. Finally, a hypothetical transient response of the system to pumping was assessed using baseline parameters with assumed storage coefficients. 


\section{General Features of the Model}

The mathematical model was constructed using the simulation code of McDonald and Harbaugh (1984). This code, referred to as a modular model because of its programming structure, uses finite-difference approximations to solve equations that describe three-dimensional ground-water movement in the saturated flow system.

The McDonald-Harbaugh code requires that the system to be modeled be subdivided, vertically and horizontally, into rectangular blocks or cells. Hydraulic properties of the flow system are assumed to be homogeneous within each cell. The saturated flow system in the Goose Lake drainage basin was subdivided vertically into four layers and horizontally into 1,239 square cells, each having dimensions of 5,000 feet per side. This finite-difference grid, shown in figure 11 , is identical to the grid used to compute recharge from deep percolation of precipitation and irrigation water.

The interbedded nature of the basin-fill sediments causes complex heterogeneity. These alternating beds can be modeled as an equivalent thickness of a homogeneous, anisotropic medium, if the thickness of the individual beds is much smaller than the thickness of the model layer (Bear, 1979). Dividing the system in this manner requires a fully three-dimensional approach, in which the entire system is modeled as a series of stacked aquifers without intervening confining beds (Weiss and Williamson, 1985, p. 769).

Vertical hydraulic-head gradients were used as the basis for subdividing the basin-fill deposits into layers. Each layer covers the entire areal extent of the basin; although layer thickness is constant, the hydraulic properties of each block vary, depending on the type of aquifer material present. The section shown in figure 19 illustrates the vertical subdivisions used in the model. These subdivisions extend into the volcanics (fig. 19) to facilitate the mathematical representation of the system; for modeling purposes, the volcanics were assumed to be homogeneous and anisotropic, and model layers within the volcanics do not correspond to real geologic boundaries.

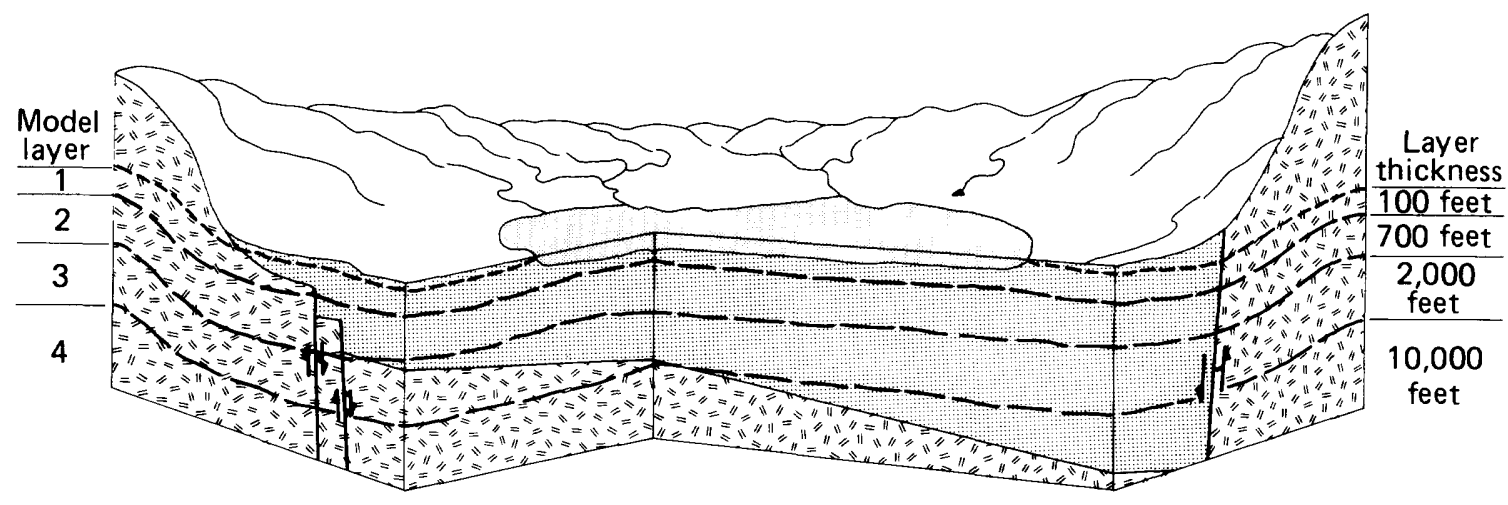

EXPLANATION

BASIN-FILL DEPOSITS

---- WATER TABLE

TERTIARY VOLCANIC ROCKS - - MODEL LAYER BOUNDARY

FAULT--Arrows indicate relative movement

Figure 19.--Diagrammatic section of basin showing layering scheme used for ground-water model analysis. 
Data from Trauger (1950) suggest that, under pre-development conditions, hydraulic heads in wells perforated below a depth of approximately 100 feet on the valley floor were up to 15 feet above those in shallower wells. The uppermost layer of the model (layer 1) was defined therefore as the upper 100 feet of the saturated flow system to represent the vertical hydraulic gradient between the shallow and deep zones.

The most heavily developed depth zone is between 100 and 800 feet. Most of the irrigation wells in the basin are open to this interval, whereas the upper 100 feet are tapped primarily by domestic wells. The 100- to 800 -foot interval therefore was defined as layer 2 in the model.

Layer 3 was defined as the average thickness of basin-fill deposits between the bottom of layer 2 and the top of the Tertiary volcanic rocks underlying the valley floor. The thickness of this interval is poorly known but oil test-well logs suggest a range of 0 to 4,200 feet; an average thickness of 2,000 feet was assumed and assigned to layer 3 . Layer 4 represents the section of Tertiary volcanics which are assumed to underlie the upper 2,800 feet (the sum of the thicknesses of layers 1-3) of basin-fill deposits and Tertiary volcanics throughout the basin. Another oil test well drilled in the upper Thomas Creek area penetrated 12,093 feet without reaching the base of the Tertiary volcanic section (Peterson and McIntyre, 1970, p. 10). An average thickness of 10,000 feet therefore was assigned to layer 4 . Because the thickness of basin-fill deposits probably varies widely within the basin, cells underlying the valley floor in layers 3 and 4 may include varying proportions of both basin-fill deposits and volcanics (fig. 19).

\section{Boundary and Initial Conditions}

Boundary conditions were specified in the model according to concepts of the flow system developed during the course of this study. An important consideration in selecting boundary conditions was the nature of the boundary between the basin-fill deposits and the volcanics. Available evidence suggested that the volcanics do not represent a nearly-impermeable boundary and that there may be a significant hydraulic connection between them and the basin-fill sediments. Thus, despite the deficiency of data describing the volcanics, they were included in the model with the hope of gaining an improved understanding of their role in the flow system. Accordingly, the model boundaries were extended to the drainage-basin boundary on the supposition that a ground-water divide coincided with its position. The ground-water divide was represented in the model as a no-flow boundary (fig. 11). The base of the Tertiary volcanic section (bottom of layer 4) was also represented as an impermeable boundary. Thus, for the baseline models, each layer was bounded on all sides by no-flow conditions and layer 4 was bounded at its base by no-flow conditions.

Potential subsurface flow across the southern boundary was investigated by substituting a headdependent flux boundary at this location during the sensitivity analysis.

The water table acts as both a recharge and discharge boundary at the upper surface of the model. Recharge was specified at all cells according to the rates estimated using the DPM-GWR model (see the section "Deep Percolation of Precipitation and Irrigation Water"). Recharge also could occur from streams as a head-dependent flux. Head-dependent flux boundaries were used to represent discharge from the upper layer by evapotranspiration, seepage to lakes, and seepage to streams. The methods and assumptions employed by these boundary conditions are described by McDonald and Harbaugh (1984).

Locations of cells in layer 1 designated as head-dependent flux boundaries to simulate streams, lakes, and subsurface inflow/outflow are shown in figure 11.

All of the sensitivity-analysis simulations were made for steady-state conditions. Solution of the finite-difference equation for ground-water flow requires that initial water levels be specified at each cell at the beginning of the simulation. When simulating steady-state conditions initial water levels do not affect model results, although if the initial water levels are close to the final calculated water levels, less computational work will be required by the model. Model-calculated drawdown was used as the measure of 
parameter sensitivity under post-development conditions. To calculate drawdown caused by the postdevelopment pumping, the calculated pre-development water levels were used as initial conditions for the post-development simulations.

\section{System Parameters}

Described below are the estimates of recharge, pumping, transmissivity, vertical leakance, lake and streambed conductances, and ET data used to construct the baseline models. Recharge and pumping rates were different for the pre- and post-development baseline models; however, all other parameters were the same.

\section{$\underline{\text { Recharge }}$}

Estimated recharge to the basin for pre-development conditions was $220,000 \mathrm{acre}-\mathrm{ft} / \mathrm{yr}$. This recharge was distributed areally according to the results of the DPM-GWR model depicted in figure 13. An additional 10,000 acre-ft/yr of recharge was specified in the post-development baseline model, due to additional irrigation from ground-water sources.

\section{Pumping}

Pumping rates for the baseline post-development model were equal to the 1985 irrigation pumpage. All withdrawals were assumed to come from model layer 2. Total pumpage of 17,200 acre-ft/yr was aggregated among 66 model cells as shown on plate $1 \mathrm{~b}$. Pumpage rates equal to 2, 4, and 8 times the 1985 pumpage were used to determine model sensitivity to errors in pumpage estimates and possible basin response to development. Zero pumping was assumed for the pre-development baseline model.

\section{Transmissivity within model layers}

Baseline transmissivity of basin-fill deposits was estimated using:

(1) Mean horizontal hydraulic conductivity of coarse- and fine-grained sediments derived from well-yield test data, and

(2) Cumulative thickness of coarse- and fine-grained sediments within model layers (figs. 6 and 7).

Estimated mean horizontal hydraulic conductivities for coarse- and fine-grained basin-fill deposits are $20 \mathrm{ft} / \mathrm{d}$ and $7 \mathrm{ft} / \mathrm{d}$ respectively and were assumed to be areally invariant in the basin. Hydraulic conductivity has been shown to decrease with depth in deep sedimentary basins due to compaction by overburden. The relation used by Durbin and others $(1978$, p. 76$)$ in developing a ground-water model of Salinas Valley, California, was a 50 percent decrease in hydraulic conductivity per 1,200 feet of depth. This relation was also assumed for the Goose Lake basin.

The percentages of coarse- and fine-grained sediments between 101 and 300 feet was used to estimate the cumulative thickness of these deposits in layer 2 (101-800 feet) and layer 3 (801-2,800 feet).

Transmissivity at each model cell within the basin-fill deposits was calculated as:

$$
\mathrm{T}=\mathrm{K}_{\mathrm{c}}^{\mathrm{h}} \mathrm{b}_{\mathrm{c}}+\mathrm{K}_{\mathrm{f}}^{\mathrm{h}} \mathrm{b}_{\mathrm{f}}
$$

where $K_{c}^{h}$ and $K_{f}^{h}$ are the horizontal hydraulic conductivities of coarse- and fine-grained sediments and $b_{c}$ and $b_{f}$ are the cumulative thickness of coarse- and fine-grained sediments within the model layer at each cell. The maximum, minumum, mean, and standard deviation of estimated basin-fill transmissivities in each layer are listed in table 8. 
Table 8.--Baseline transmissivity: Basin-fill deposits

[Values are in feet squared per day]

\begin{tabular}{ccccc}
\hline Layer & Minimum & Maximum & Mean & Standard deviation \\
\hline 1 & 302 & 1,870 & 1,340 & 294 \\
2 & 2,100 & 12,200 & 9,080 & 2,100 \\
3 & 6,000 & 28,000 & 19,600 & 4,660 \\
14 & -- & -- & -- & -- \\
\hline
\end{tabular}

1Layer 4 is assumed not to contain basin-fill deposits.

The horizontal hydraulic conductivity of each model cell representing the volcanic-rock sequence surrounding and underlying the basin-fill deposits was assumed to be constant both areally and with depth. The baseline horizontal hydraulic conductivity of $3 \mathrm{ft} / \mathrm{d}$ was used to calculate transmissivities of 300 feet squared per day $\left(\mathrm{ft}^{2} / \mathrm{d}\right), 2,100 \mathrm{ft}^{2} / \mathrm{d}, 6,000 \mathrm{ft}^{2} / \mathrm{d}$, and $30,000 \mathrm{ft}^{2} / \mathrm{d}$ for layers $1-4$.

Vertical leakance between model layers

Vertical leakance is the property of the flow system that describes its resistance to vertical groundwater movement. The vertical leakance between two adjacent model layers is approximately equal to $\mathrm{K}_{\mathbf{v}} / \mathrm{b}_{\mathrm{f}}$, where $\mathrm{K}_{\mathrm{v}}$ is the vertical hydraulic conductivity of fine-grained sediments and $\mathrm{b}_{\mathrm{f}}$ is the cumulative thickness of fine-grained sediments between the centers of adjacent layers. The resistance to vertical flow caused by coarsegrained sediments is comparatively small and can be neglected. Vertical leakance within the basin-fill deposits of Goose Lake basin was calculated by dividing the baseline value of vertical hydraulic conductivity of these deposits $(0.02 \mathrm{ft} / \mathrm{d})$ by the cumulative thickness of fine-grained sediments between layers at each cell. As an example, the vertical leakance $(\mathrm{VL})$ between layers $k$ and $k+1$ at cell $i, j$ would be calculated as:

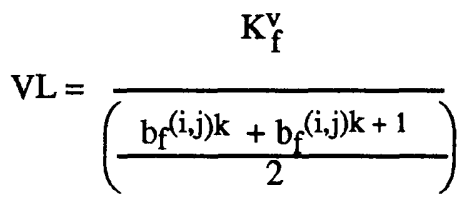

Vertical-leakance values between basin-fill cells adjacent to basin-fill cells and basin-fill cells overlying volcanic cells (layers 3 and 4 ) are listed in table 9.

Table 9.--Baseline vertical leakance: Basin-fill deposits

[All values are in units of days-1]

\begin{tabular}{rllll}
\hline Layers & Minimum & Maximum & Mean & Standard deviation \\
\hline $1-2$ & $8 \times 10^{-6}$ & $3 \times 10-4$ & $1 \times 10^{-4}$ & $4 \times 10-5$ \\
$2-3$ & $3 \times 10^{-6}$ & $8 \times 10-5$ & $3 \times 10-5$ & $2 \times 10-5$ \\
$13-4$ & $5 \times 10^{-7}$ & $5 \times 10-7$ & $5 \times 10-7$ & 0 \\
\hline
\end{tabular}

${ }^{1}$ Basin-fill cells (layer 3) underlain by volcanic cells (layer 4). 
The volcanics were assumed to be homogeneous and vertically anisotropic with respect to hydraulic conductivity; the degree of anisotropy was assumed to be constant areally and with depth. Model studies of ground-water flow within the thick, Tertiary volcanic sections on the Columbia Plateau in Oregon and Washington have suggested that horizontal to vertical anisotropy ratios of 1,000:1 are not unreasonable (William Meyer, U.S. Geological Survey, Tacoma, Washington, oral commun., June 1986). Lacking other data, this ratio was adopted as the baseline estimate for this analysis. The resulting vertical-leakance values between volcanic cells adjacent to volcanic cells were $8 \times 10^{-6} \mathrm{~d}^{-1}$ between layers 1 and $2,3 \times 10^{-6} \mathrm{~d}^{-1}$ between layers 2 and 3 , and $5 \times 10^{-7} d^{-1}$ between layers 3 and 4 .

\section{Lakebed conductance}

Interchange of water between lakes and reservoirs and the saturated ground-water system was simulated using head-dependent flux boundaries. Goose Lake and Drews and Cottonwood Reservoirs were represented in this way (fig. 11). The mean surface elevation of the water body must be specified as well as the conductance of the lakebed and other fine-grained deposits between the lake bottom and the center of the underlying model cell. Lakebed conductances were estimated by assuming that (1) the vertical hydraulic conductivity of lakebed deposits was equal to that of other fine-grained deposits $(0.02 \mathrm{ft} / \mathrm{d})$ and (2) the average thickness of lakebed deposits plus fine-grained sediments in the upper half (50 feet) of layer 1 was 50 feet. Lakebed conductances (LC) were calculated using the equation:

$$
\mathrm{LC}=\underline{\mathrm{KvA}}
$$

where $\mathrm{K}^{\mathrm{v}}$ is the vertical hydraulic conductivity of lakebed and fine- grained sediments, $\mathrm{A}$ is the area of the model cell covered by the lake and $b$ is the combined thickness of lakebed and fine-grained sediments. The conductance of a $25 \times 10^{6}$-square-foot cell entirely overlain by a lake is therefore

$$
(0.02)\left(25 \times 10^{6}\right)=10,000 \mathrm{ft}^{2} / \mathrm{d}
$$

50

This was the baseline conductance used at all lake cells.

Streambed conductance

Ground-water discharge to and recharge from streams also was simulated using head-dependent flux boundaries in a manner described by McDonald and Harbaugh (1984, p. 218). Data required to simulate the effects of streams include average stream stage, stream-channel altitude, and streambed conductance. All major streams in the basin were simulated in this way (see fig. 11).

All stream-channel altitudes were estimated from topographic maps and mean stage was estimated to be 1 foot. The vertical leakance $(\mathrm{Kv} / \mathrm{b})$ between the stream channel and the center of the underlying model cell was estimated to be $0.02 \mathrm{~d}^{-1}$ for stream reaches in the basin-fill deposits and $0.003 \mathrm{~d}^{-1}$ for reaches in the upland volcanics. The conductance equation for streambeds is the same as that for lakebeds; therefore, baseline conductances varied depending on the width and length of stream reaches within individual model cells.

\section{Evapotranspiration data}

Discharge from the water table by evapotranspiration was simulated by assuming a linear relation between discharge and depth to the water table (McDonald and Harbaugh, 1984, p. 316). Data required to define this relation are the potential ET rate (in/yr), depth below land surface at which ET becomes zero, and 
land-surface altitude. Actual ET rates at each cell are computed on the basis of the simulated water-table altitude; ET reaches the potential rate if the water table in the cell is at land surface and falls to zero if the water table drops below the specified extinction depth.

The potential ET rate for discharge from the saturated zone was assumed to be equal to the residual of potential ET ( $42 \mathrm{in} / \mathrm{yr}$ ) minus mean ET from the unsaturated root zone (12 in/yr). Mean annual unsaturatedzone ET was computed using the DPM-GWR model (see "Deep Percolation of Precipitation and Irrigation Water"). This residual, $30 \mathrm{in} / \mathrm{yr}$, was assumed to be the maximum ET rate possible from the saturated zone. Average land-surface altitude for each model cell was estimated from digital elevation data for the basin and ET from the saturated zone was presumed to cease if the water table was more than 10 feet below land surface.

\section{Limitations on the Use of the Model}

Many simplifying assumptions are necessary to represent the conceptual model of a ground-water system within the framework of a mathematical model. Most of the assumptions used to develop the model of the Goose Lake basin have been fully discussed and justified; however, some assumptions limit the application of the model for addressing specific questions.

The first assumption is that transmissivities of the uppermost layers of the model do not vary with time. This assumption is valid for pre-development conditions, but prolonged pumping during postdevelopment simulations lowers the water table and reduces the saturated thickness, and therefore the transmissivity, of the uppermost model layer. If the change in saturated thickness of the layer is small compared to its total thickness, changes in transmissivity can be ignored. This condition may be violated in layer 1 for some simulations, since its thickness is only 100 feet. The assumption should be valid for the 700foot thick layer 2 for most simulations. Additional error would result in simulations where hydraulic heads in layer 1 fell more than 100 feet, making layer 2 an unconfined, or water-table, unit. Water recovered from storage in such a unit should come from gravity drainage; however, the model storage coefficient would not reflect this change. The model code used in this study has provisions for simulating variation in transmissivity and storage properties with time; however, insufficient data were available for this study to utilize these options. Specifically, data describing the depth to the water table at each model cell would be required. The assumption that transmissivity is time-invariant would result in simulated drawdowns less than would actually occur. Transient simulation of layer 2 as a confined zone--when it is actually unconfined-would show more rapid water-level declines than would actually occur.

Second, delayed release of water from storage in thick, fine-grained interbeds is not considered by the model. This phenomenon, commonly referred to as transient leakage, could increase the time required for the ground-water system to reach a new equilibrium following the onset of pumping. Transient leakage would be important only if thick, fine-grained beds were located within areas of heavy withdrawals and would affect only the results of transient simulations.

A third assumption affecting the use of models developed in this study is the use of no-flow boundary conditions to represent ground-water divides in post-development simulations. The effect of this assumption is to increase the predicted drawdown. The error introduced by assuming no flow across boundaries is greater for higher levels of pumping stress and is locally greater where pumping wells are near boundaries.

The hydraulic heads (or drawdowns) computed at each cell using the simulation model represent the average heads (or drawdowns) within the volume of that cell. Actual hydraulic head or drawdown may vary considerably within the areas and depths covered by model cells in this analysis. Each cell covered an area of nearly 1 square mile and had a thickness of from 100 to 10,000 feet. Actual drawdown in wells can show considerable variation due to aquifer properties near the well, depth of the well, and construction methods used. 
A gross simplification, used in this model because of limited available data, was that volcanic rocks had uniform permeability. On the basis of overall lithology, some of the volcanic rocks undoubtedly have lower permeability and are accurately represented as no-flow boundaries to the system. Specifically, the older Tertiary volcanic rocks crop out in and underlie the Warner Mountains and probably form a nearly impermeable barrier to ground-water movement on the east side of the basin.

Finally, no "history-matching" or model calibration was performed for this study. The model was developed and used primarily as an investigative tool to assess and refine the conceptual model of the system and to determine the sensitivity of the model to data errors. The model is therefore not considered to be a predictive tool for forecasting the exact hydrologic impacts of specific ground-water development scenarios. The model does provide a means of defining ranges of hydrologic impacts that might result from pumping at given rates and locations--with the ranges defined by uncertainties in system parameters and boundary conditions.

\section{Baseline Model Results}

The pre- and post-development models were run with the estimated baseline parameters and boundary conditions discussed in the previous sections. These runs did not involve adjustment of parameters, or calibration, to match observed hydrologic conditions. The purpose of these runs was to (1) evaluate baseline model representation of the conceptual model of the system and (2) provide measures of baseline model response, such as mean deviation and drawdown, for determining model sensitivity to uncertainty in parameters.

\section{Pre-development Model}

The pre-development model successfully simulated many features of the ground-water flow system in the basin. Model-computed hydraulic heads in layers 1 and 2 are shown in figures 20-a and 20-b respectively. Contours of observed heads (Trauger, 1950; California Department of Water Resources, 1963) are shown for comparison. Water levels measured by Trauger (1950) and CDWR (1963) during the pre-development period were averaged within model cells for comparison with computed water levels. The locations of cells for which observed water levels were available are shown in figures 20-a and 20-b. Sixty-one cells representing the shallow-aquifer zone and 27 cells representing the deeper zones were used to compute the mean deviations for each zone. Frequency curves of deviation of computed from observed heads at individual cells are shown in figure 21 . Fifty percent of cells where observed-head data were available had deviations of 26 feet or less in layer 1 and 52 feet or less in layer 2 . Ninety percent of computed heads in cells in both layers deviated by less than 100 feet from observed heads. Deviations of more than 100 feet were mostly at cells in the volcanic upland areas. Model-computed heads were almost universally greater than observed heads; explanations for this result are discussed later. The mean deviation was 73 feet for layer 1 and 109 feet for layer 2.

Horizontal hydraulic gradients in the simulated pre-development flow system are from the upland recharge areas toward the principal discharge area on the valley floor. Hydraulic gradients in Drews Valley also show discharge from the shallow subsystem to Drews Reservoir. The direction of vertical hydraulic gradients between layer 1 and layer 2 in the mathematical model are consistent with those suggested by field data and the conceptual model. Vertical hydraulic gradients are downward throughout most of the upland recharge area and upward under discharge areas of the valley floor. Simulated fluxes between layers were $160,000 \mathrm{acre}-\mathrm{ft} / \mathrm{yr}$ between 1 and 2, 67,000 acre-ft/yr between 2 and 3, and 6,500 acre-ft/yr between 3 and 4 .

The computed pre-development ground-water budget for the basin is shown in table 10 .

Of the simulated seepage to lakes, 14,000 acre-ft/yr was discharged to Drews Reservoir. The remaining $62,000 \mathrm{acre}-\mathrm{ft} / \mathrm{yr}$ of simulated seepage to Goose Lake is approximately half of the 130,000 acre$\mathrm{ft} / \mathrm{yr}$ estimated using the lake-budget method; explanations for this difference will be presented in the discussion of the sensitivity analysis.

\section{Post-development Model}

Hydrologic stresses on the flow system caused by increased pumping for irrigation and increased recharge resulting from that irrigation were simulated using the post-development model. The pumping stress was equivalent in magnitude and distribution to irrigation pumping that occurred in 1985 (pl. 1b). 


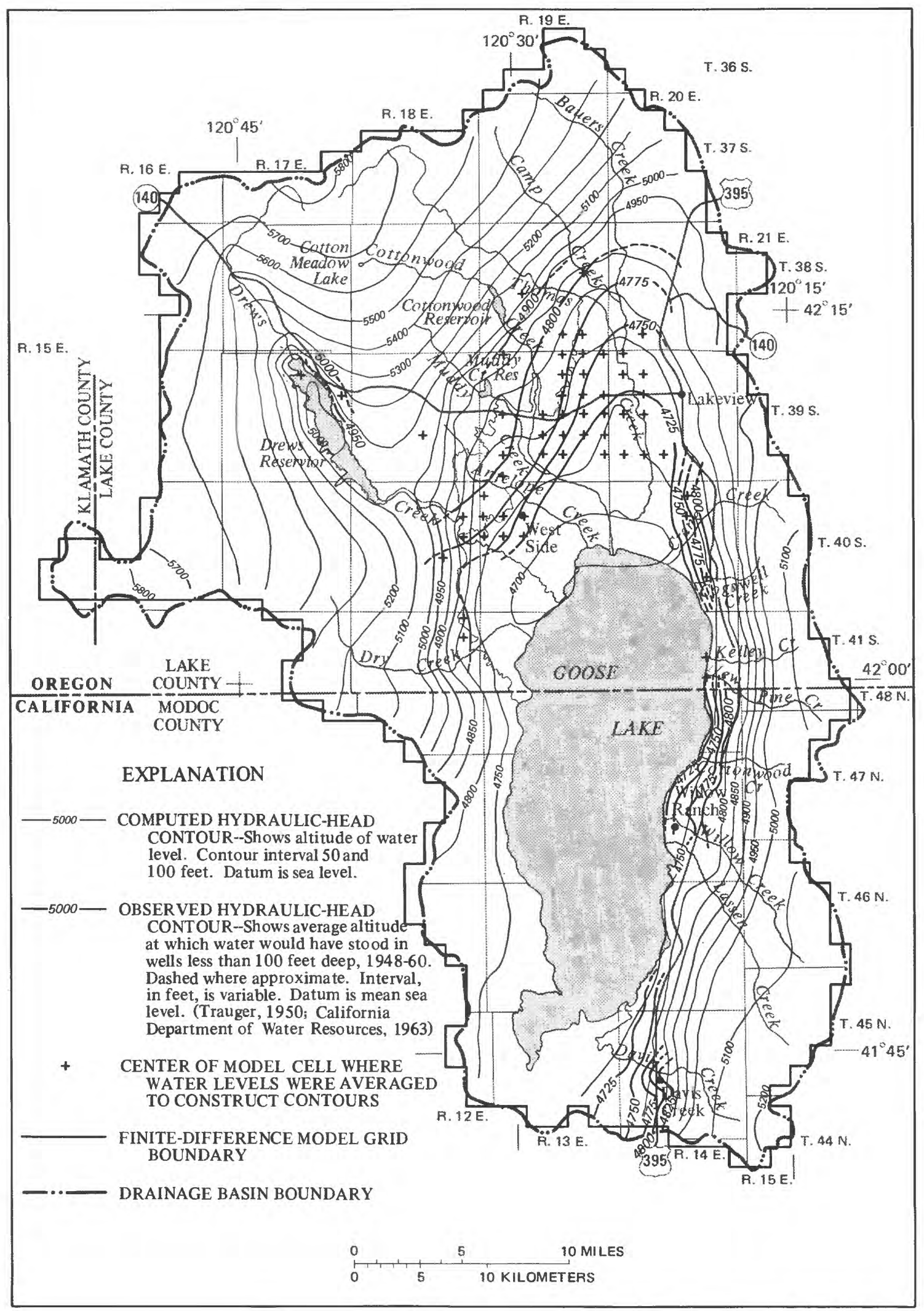

Figure 20a.--Simulated and observed hydraulic heads for pre-development base-line conditions: Layer 1. 


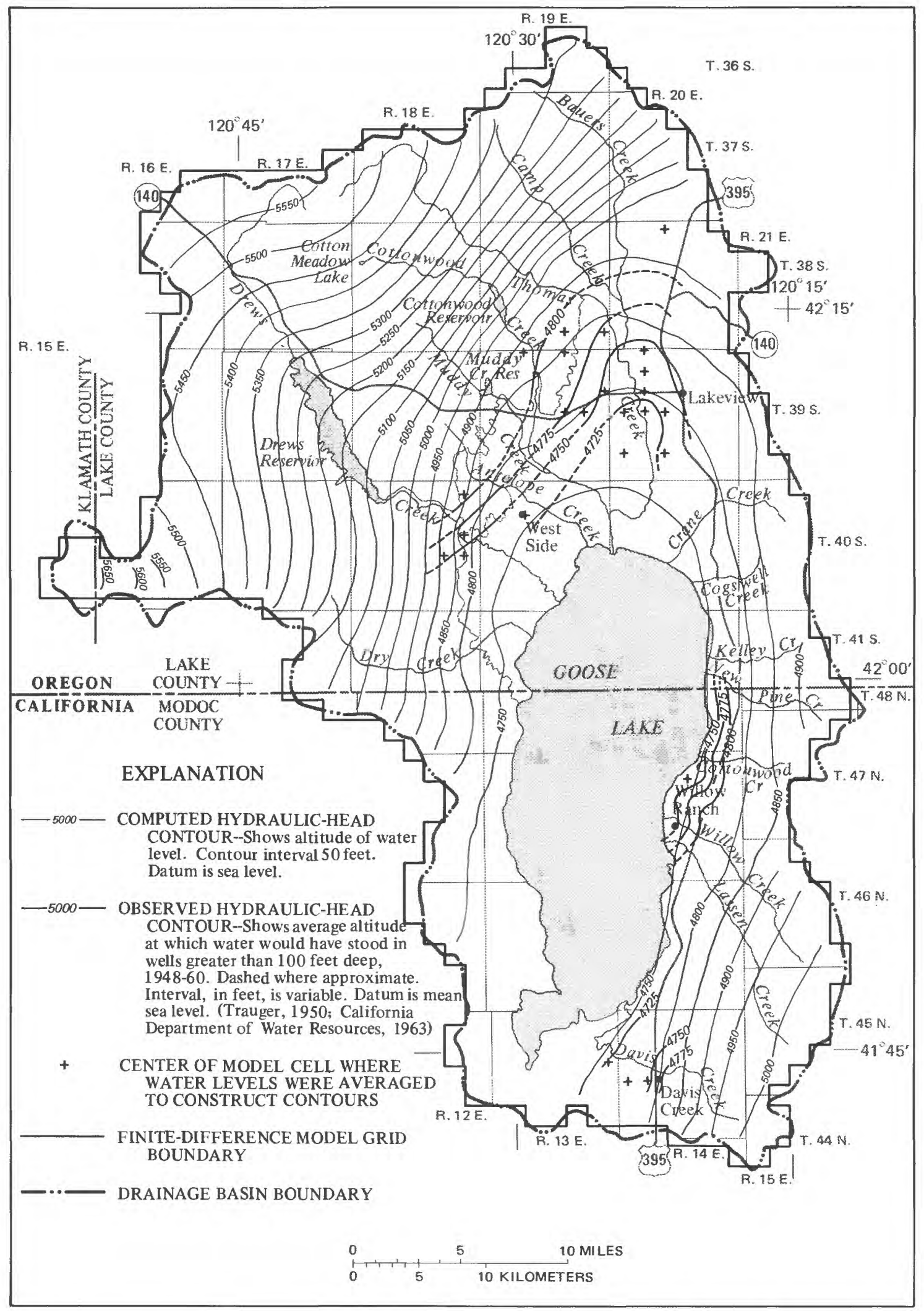

Figure 20b.--Simulated and observed hydraulic heads for pre-development base-line conditions: Layer 2. 


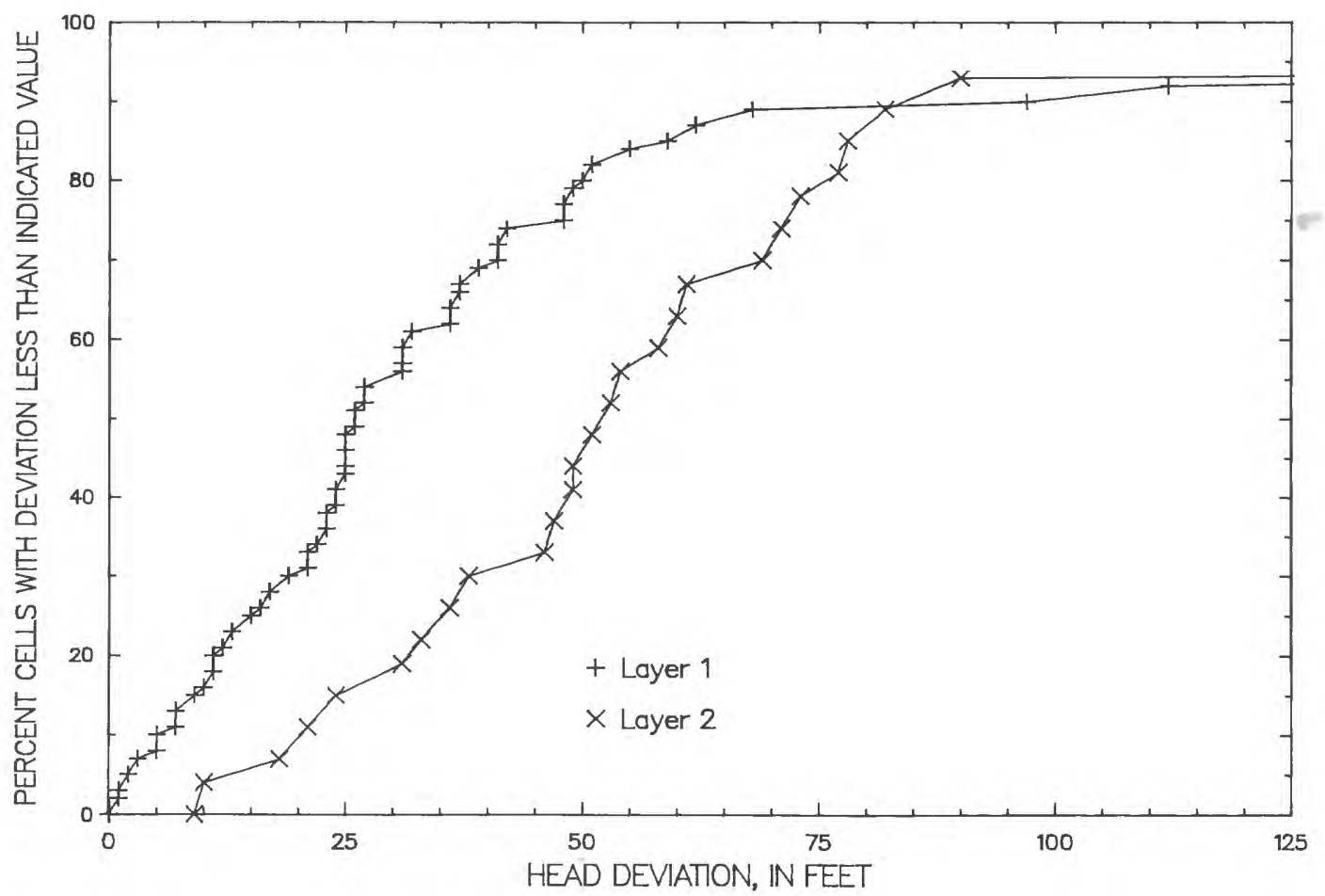

Figure 21.--Frequency distribution of deviations between observed and computed hydraulic heads for pre-development base-line conditions.

Table 10.--Pre-development ground-water budget for the Goose Lake basin computed using the baseline model parameters

\begin{tabular}{|c|c|c|}
\hline \multirow[b]{2}{*}{ Parameters } & \multicolumn{2}{|c|}{ Budget amounts } \\
\hline & Acre-ft/yr & $\mathrm{Ft}^{3} / \mathrm{s}$ \\
\hline \multicolumn{3}{|l|}{ INFLOW } \\
\hline $\begin{array}{l}\text { Deep percolation of precipitation } \\
\text { and irrigation (surface water only) }\end{array}$ & 221,000 & 305 \\
\hline Seepage from streams & 1,000 & 1 \\
\hline Total & $=222,000$ & 306 \\
\hline \multicolumn{3}{|l|}{ OUTFLOW } \\
\hline Evapotranspiration & 124,000 & 171 \\
\hline Seepage to lakes & 76,000 & 105 \\
\hline Seepage to streams & 23,000 & 32 \\
\hline \multirow[t]{3}{*}{ Subsurface flow } & 0 & 0 \\
\hline & $=223,000$ & 308 \\
\hline & $\begin{array}{r}-1,000 \\
0\end{array}$ & 0.5 percent \\
\hline
\end{tabular}


Areal recharge from deep percolation of irrigation water was increased by $9,000 \mathrm{acre}-\mathrm{ft} / \mathrm{yr}$ to simulate the effects of additional irrigation from ground water. All system parameters and boundary conditions were identical to those used in the pre-development baseline model.

The model was used to calculate changes in water level from pre-development equilibrium conditions to new equilibrium conditions induced by the post-development stresses. Actually, increases in recharge or discharge cause changes in aquifer storage that occur over time periods whose length is dependent on the storage properties of the aquifer system and the magnitude and location of the recharge and (or) discharge. These changes in storage and the time required for them to occur were not considered in this simulation or in the post-development sensitivity analysis. The water-level changes (computed by the model) are those that would occur after changes in aquifer storage had ceased, that is, after a new equilibrium had been achieved.

Computed water-level changes in layers 1 and 2 are shown in figures 22-a and 22-b. Maximum computed drawdowns (about 20 feet) occur in layer 2 on the west side of the valley in the northeast corner of T. 40 S., R. 18 E., where most of the high-capacity wells in the basin are located. Maximum drawdowns of 6-12 feet are shown near Davis Creek, California, and in T. 37 S., R. 20 E where additional irrigation wells are concentrated. Equilibrium drawdowns in layer 2 are more than 2 feet over most of the northern basin. Maximum drawdowns in layer 1 are 4-8 feet and overlie the most heavily pumped areas of layer 2. Equilibrium water-level increases of up to 4 feet over pre-development levels were computed in layer 1 where additional irrigation was applied. Mean equilibrium water-level declines were 2.5 feet in layer 1 and 7.2 feet in layer 2.

The computed post-development ground-water budget for the basin is listed in table 11 .

Table 11.--Post-development ground-water budget for the Goose Lake basin computed using the baselinemodel parameters

\begin{tabular}{|c|c|c|c|}
\hline \multirow[b]{2}{*}{ Parameters } & & \multicolumn{2}{|c|}{ Budget amounts } \\
\hline & & Acre-ft/yr & \multirow[t]{2}{*}{$\mathrm{Ft}^{3} / \mathrm{s}$} \\
\hline \multicolumn{3}{|l|}{ INFLOW } & \\
\hline $\begin{array}{l}\text { Deep percolation of precipitation } \\
\text { and irrigation (surface and ground water) }\end{array}$ & & 230,000 & 318 \\
\hline Seepage from streams & & 1,000 & 1 \\
\hline \multicolumn{4}{|l|}{ OUTFLOW } \\
\hline $\begin{array}{l}\text { Evapotranspiration } \\
\text { Seepage to lakes }\end{array}$ & & $\begin{array}{r}120,000 \\
74,000\end{array}$ & $\begin{array}{l}166 \\
103\end{array}$ \\
\hline Seepage to streams & & 22,000 & 31 \\
\hline Subsurface flow & & 0 & 0 \\
\hline Pumping & & 17,000 & 24 \\
\hline & Total $=$ & 233,000 & 324 \\
\hline Mass balance error $=$ Inflow - outflow & $\begin{array}{l}= \\
=\end{array}$ & $\begin{array}{r}-2,000 \\
0\end{array}$ & ercent 5 \\
\hline
\end{tabular}




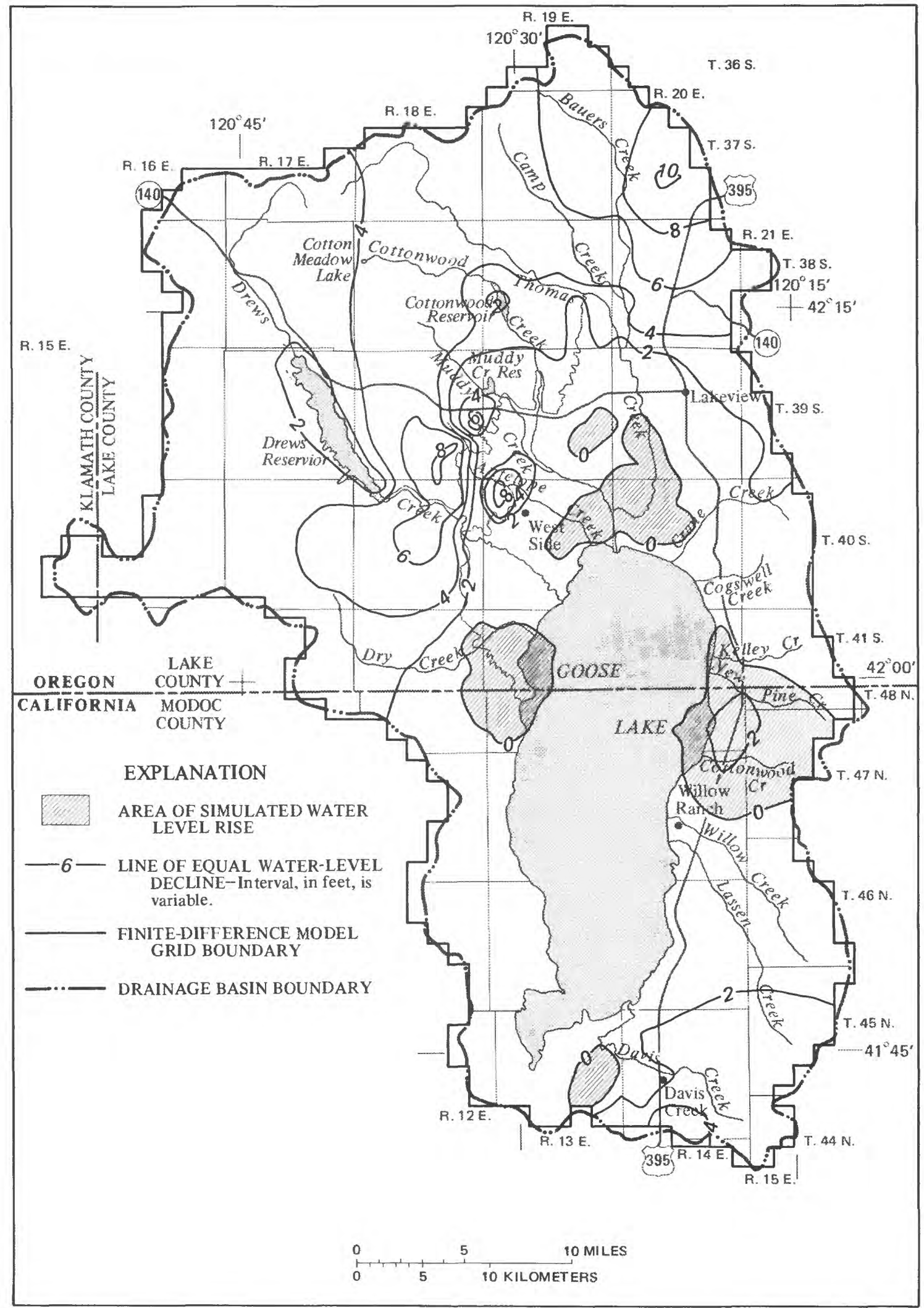

Figure 22a.--Simulated equilibrium water-level changes for post-development base-line conditions with pumping equal to 17,200 acre-feet/year (1985 rate): Layer 1 . 


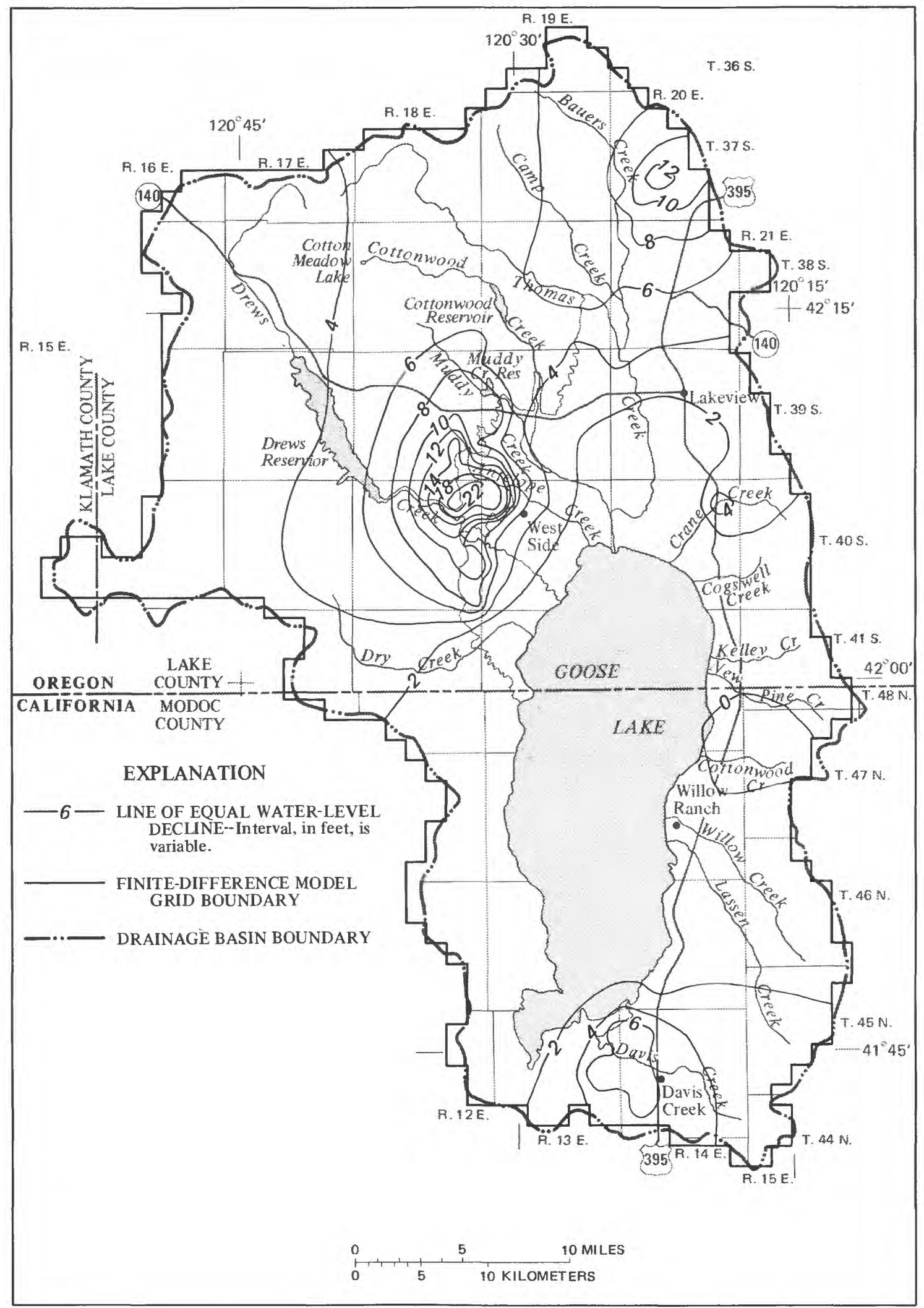

Figure 22b.-mimulated equilibrium water-level changes for post-development base-line conditions with pumping equal to 17,200 acre-feet/year (1985 rate): Layer 2. 
The ground-water budget for simulated post-development equilibrium conditions shows that pumping is offset by additional recharge and reductions in natural discharge. These are the rates of discharge that would be expected after changes in aquifer storage and water-level declines ceased. Most of the reduction in natural discharge was gained from ET. Under pre-development conditions, vertical hydraulic-head gradients were upward over much of the valley floor. Simulation results show that pumping reduced or reversed the vertical hydraulic-head gradient in parts of the valley, inducing drawdown in the shallow zone (layer 1) that reduced simulated discharge by ET and seepage to Goose Lake.

The simulated influence of pumping extends to the boundary of the drainage basin in nearly all directions. The drainage basin boundary was represented in both the pre- and post-development models as a noflow boundary. This representation is a valid treatment of the ground-water divide for an unstressed system in which the location of the boundary can be assumed constant. However, stresses on the natural system whose influence extends to the boundary would cause the location of the real ground-water divide to change. Use of a no-flow boundary in this case would cause the model to predict unrealistically high drawdown.

The purpose of simulating post-development conditions in this study was not to predict water-level changes related to pumping, but to assess the potential errors in a model constructed using only available data. Considering this purpose, the use of a stationary, no-flow boundary to represent the ground-water divide is reasonable.

\section{Sensitivity Analysis}

The sensitivity analysis consisted of two phases. In each phase the sensitivity of the model to uncertainty in system parameters and boundary conditions was tested for both pre- and post-development conditions. In the first phase, a series of simulations was made for each parameter wherein only that parameter was varied. Parameters were varied over ranges defined by either (1) semi-quantitative estimates of parameter uncertainty or (2) subjective estimates of the maximum and minimum "reasonable" values of the parameter for the Goose Lake basin. This phase of the analysis is referred to as the "single-parameter" sensitivity analysis. In the second phase, several parameters were altered from baseline values for one "multiple-parameter" sensitivity simulation. This simulation was designed to show the additive effects of parameter uncertainty on model results.

The measures used to evaluate pre-development model sensitivity were (1) mean deviation of computed from observed hydraulic head at selected cells in layers 1 and 2, (2) mean hydraulic head at all cells in layers 1 and 2, and (3) computed rates of natural discharge. Mean hydraulic head was used to measure the basin-wide response of the model, by layer, to changes in parameters. Mean head was also a useful indicator of the overall direction of water-level changes in response to a parameter change. Post-development model sensitivity was gaged using (1) mean water-level changes at cells where pumping wells are located and (2) computed rates of natural discharge.

In the following discussion of the procedure used in the first phase, the results of each series of simulations are shown graphically in sensitivity plots of parameter values versus measures of model response. Phase one results are then summarized and contour maps of computed hydraulic-head and water-level changes for selected simulations are shown to illustrate the effects of parameter changes on hydraulic gradients and water level changes.

\section{Procedure}

Model sensitivity to recharge and pumping rates was determined using the pre- and post-development models respectively. Pumping rates of 2, 4, and 8 times the estimated 1985 rate of $17,200 \mathrm{acre}-\mathrm{ft} / \mathrm{yr}$ were tested with the post-development model. Subsequent post-development sensitivity simulations were made using a pumping rate equal to 8 times the estimated 1985 rates to induce the greatest response for comparing sensitivities. The details related to each series of single-parameter sensitivity simulations are listed below, followed by a summary of the results of the single-parameter sensitivity analysis. 
(1) Recharge: Recharge from deep percolation of precipitation and irrigation was varied from 170,000 acrefeet/yr ( 77 percent of the baseline estimate) to $305,000 \mathrm{acre}-\mathrm{ft} / \mathrm{yr}$ (138 percent of the baseline estimate). These are the minimum and maximum average annual rates computed using the DPM-GWR model. Predevelopment model sensitivity plots of recharge versus mean deviation, head, and natural-discharge rates are shown in figures 23-a and 23-b.

(2) Pumping: The sensitivity of the post-development model to pumping stress was tested by imposing pumping rates of 2,4 , and 8 times the estimated 1985 , or baseline, pumping rate. Total withdrawal rates for these simulations were $34,400,68,800$, and 138,000 acre-ft/yr. The location of pumping wells was the same for each simulation, as shown on plate $1 \mathrm{~b}$. Post-development model-sensitivity plots of pumping rate versus simulated mean drawdown and natural discharge rates are shown in figures 24-a and 24-b.

(3) Transmissivity: Model sensitivities to transmissivity of the basin-fill and the volcanics were determined separately because of the great contrast in the hydraulic character of the two units. Additionally, uncertainty in estimated transmissivity of the basin-fill deposits is considerably less than that for the volcanics.
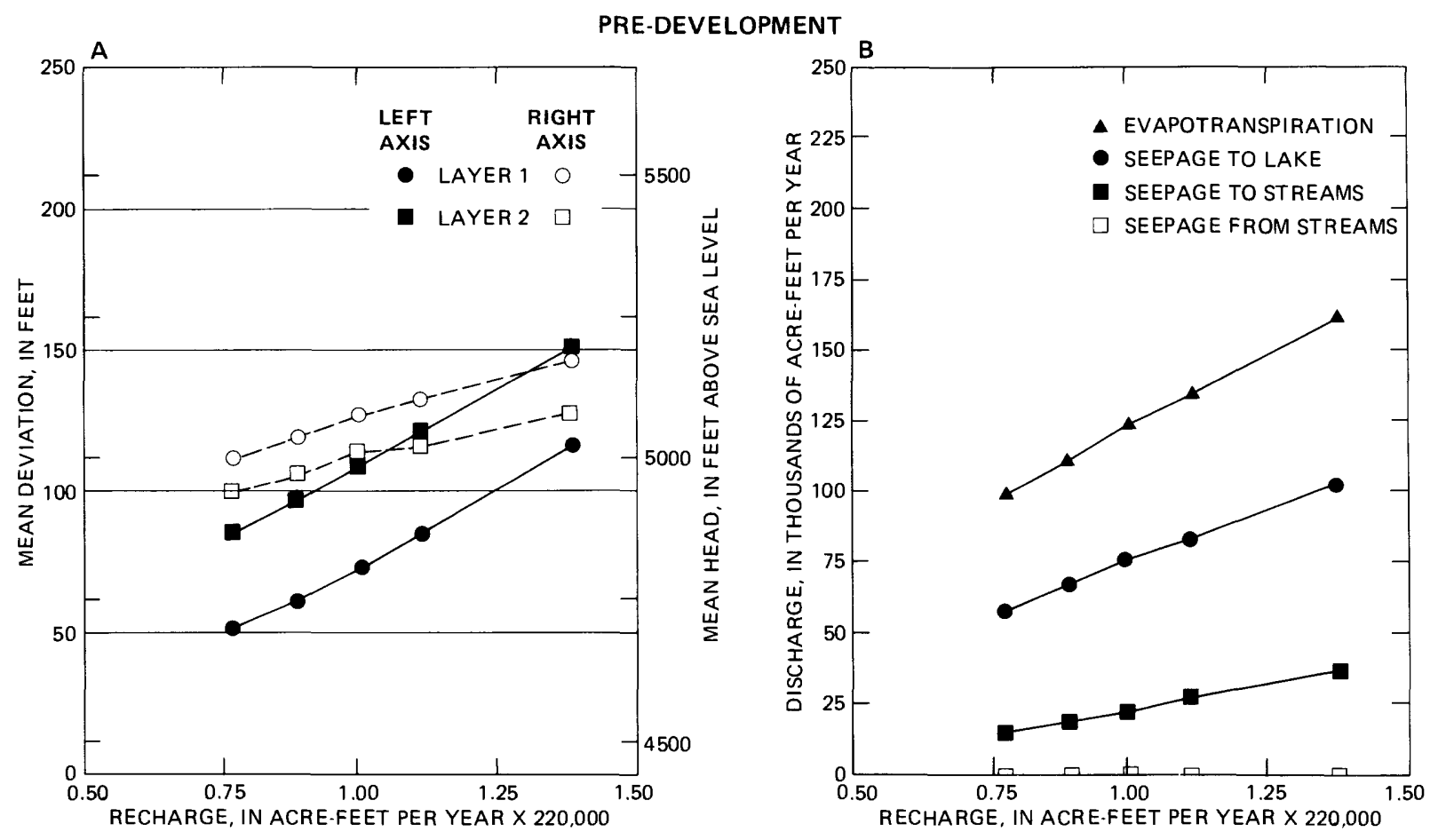

Figure 23.--Sensitivity of simulated heads and discharge to uncertainty in recharge estimates: (A) Recharge plotted against (1) mean deviation of computed from observed pre-development heads in layers 1 and 2, and (2) mean head in layers 1 and 2. (B) Recharge plotted against pre-development discharge by evapotranspiration and seepage to streams and lakes. 

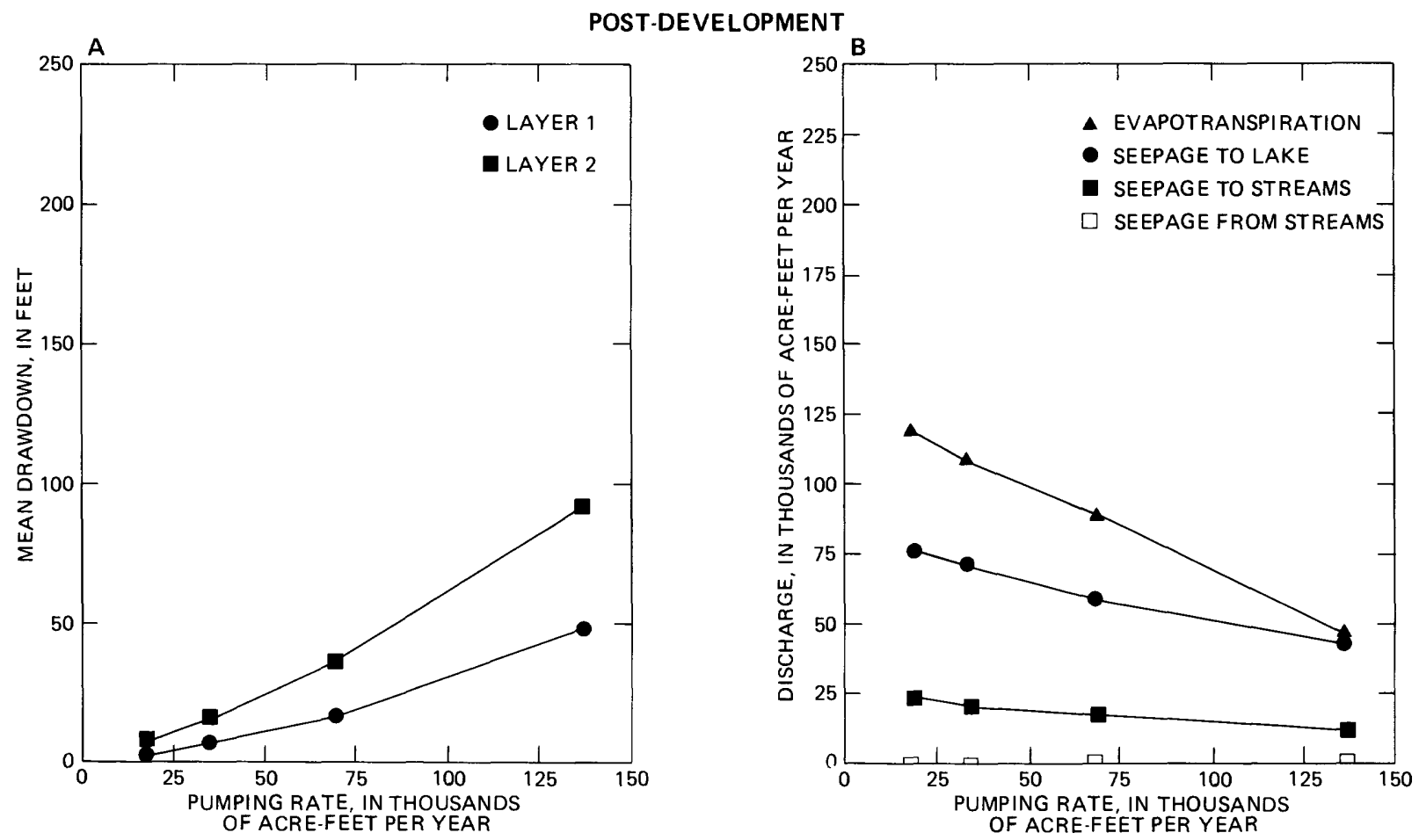

Figure 24.--Sensitivity of simulated drawdown and natural discharge rates to changes in pumping:

(A) Pumping plotted against mean equilibrium drawdown at pumping locations in layers 1 and 2.

(B) Pumping plotted against natural discharge by evapotranspiration and seepage to streams and lakes.

Transmissivity of the basin-fill deposits (BT) was varied from one order of magnitude less, to two orders of magnitude more than the baseline values. This variability resulted in ranges of mean BT equal to $130-130,000 \mathrm{ft}^{2} / \mathrm{d}$ in layer $1,900-900,000 \mathrm{ft}^{2} / \mathrm{d}$ in layer 2 , and $2000-2,000,000 \mathrm{ft}^{2} / \mathrm{d}$ in layer 3. Pre-development model sensitivity plots of BT versus mean deviation, head, and natural discharge rates are shown in figures 25-a and 25-b. Post-development model-sensitivity plots of BT versus mean drawdown and natural discharge rates are shown in figures $25-\mathrm{c}$ and 25 -d.

The range of transmissivity of the volcanic rocks (VT) tested spanned three orders of magnitude from 0.1 to 100 times baseline values. Given that each model layer is of constant thickness and that the volcanics are assumed to be homogeneous, the range of VT tested can be considered a range of equivalent horizontal hydraulic conductivity for the volcanic rocks. The range, 0.3-300 ft/d, is representative of ranges reported in the literature (Wolff, 1982, table 4.3.3) for similar rock assemblages. Vertical leakance of the volcanics was not varied and thus the vertical anisotropy was not consistent between simulations. The effective ratio of horizontal to vertical hydraulic conductivity $\left(\mathrm{K}^{\mathrm{h}} / \mathrm{K}^{\mathrm{v}}\right)$ is listed below for each simulation:

\begin{tabular}{|c|c|c|c|c|c|c|}
\hline $\begin{array}{l}\text { Baseline } \\
\text { transmissivity } \\
\text { values, times: }\end{array}$ & 0.1 & 0.3 & 1.0 & 1.7 & 10 & 100 \\
\hline Effective & & & & & & \\
\hline ratio $\mathrm{K}^{\mathrm{h}} / \mathrm{K}^{\mathrm{v}}$ : & 100 & 300 & 1,000 & 1,700 & 10,000 & 100,000 \\
\hline
\end{tabular}

Values of $\mathrm{K}^{\mathrm{h}} / \mathrm{K}^{\mathrm{v}}$ greater than 10,000 are not generally considered reasonable but are a side effect of the procedure used. Pre-development model-sensitivity plots of VT versus mean deviation, head, and natural discharge rates are shown in figures 26-a and 26-b. Post-development model-sensitivity plots of VT versus mean drawdown and natural discharge rates are shown in figures 26-c and 26-d.

(4) Vertical leakance: Model sensitivity to vertical leakance was analyzed separately for the basin-fill deposits and the volcanics because of the large contrast in hydraulic characteristics between the two units. 

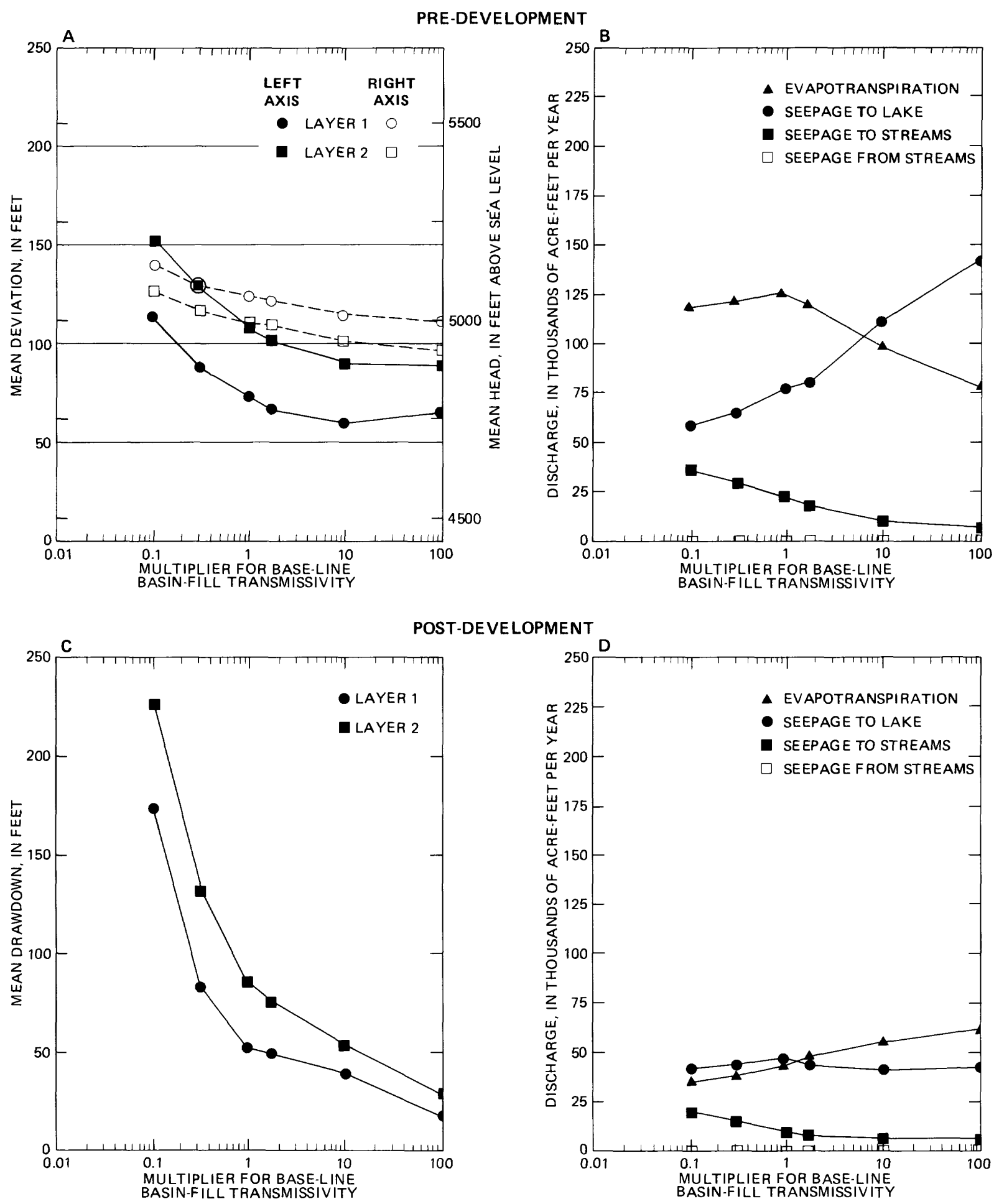

Figure 25.--Sensitivity of simulated heads, drawdown, and discharge to uncertainty in estimates of basin-fill transmissivity: (A) Transmissivity plotted against pre-development (1) mean deviation of computed from observed heads in layers 1 and 2, and (2) mean head in layers 1 and 2. (B) Transmissivity plotted against pre-development discharge by evapotranspiration and seepage to streams and lakes. (C) Transmissivity plotted against post-development drawdown at pumping locations in layers 1 and 2. (D) Transmissivity plotted against post-development discharge by evapotranspiration and seepage to streams and lakes. 
PRE-DEVELOPMENT
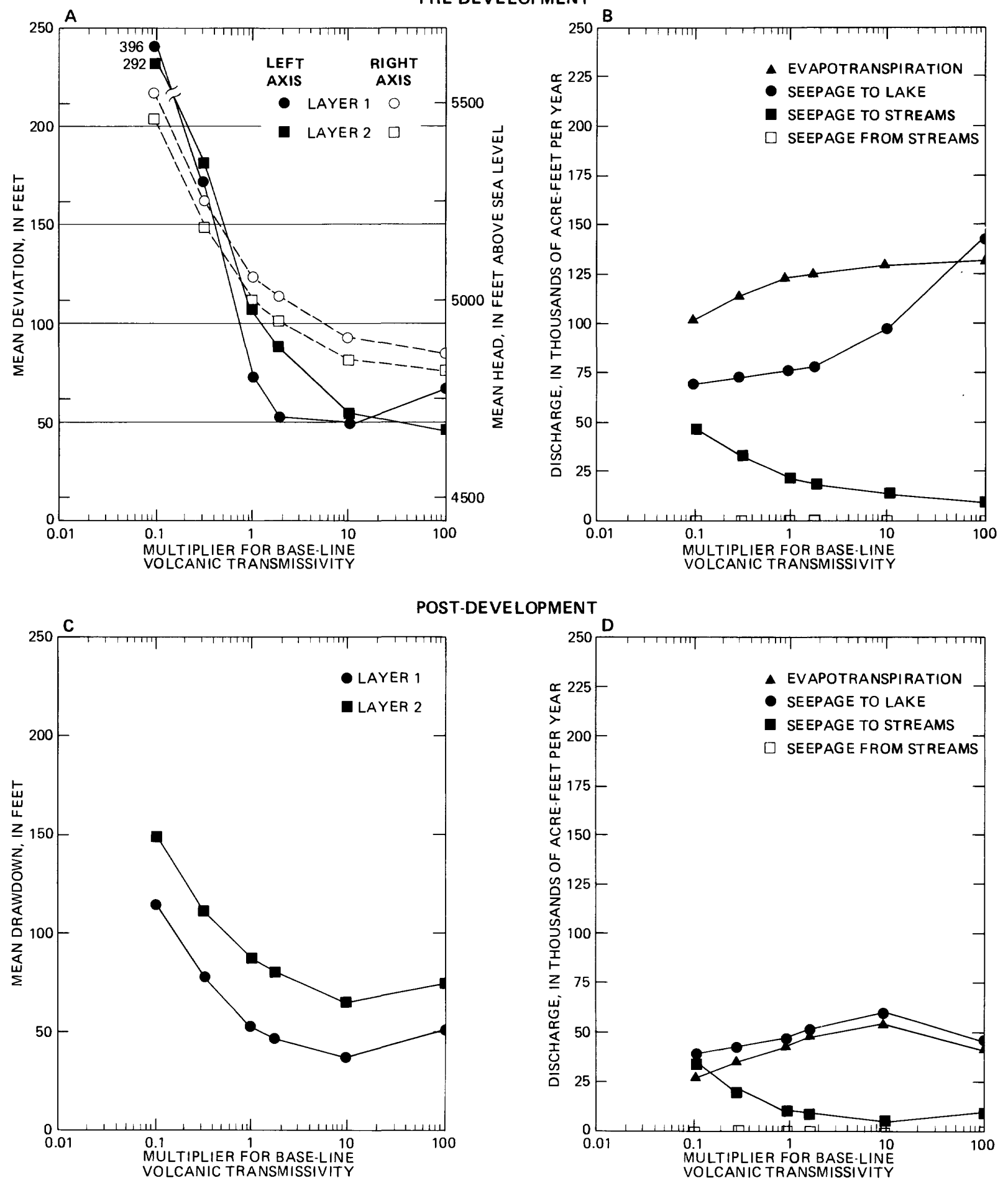

Figure 26.--Sensitivity of simulated heads, drawdown, and discharge to uncertainty in estimates of volcanic transmissivity: (A) Transmissivity plotted against (1) mean deviation of computed from observed pre-development heads in layers 1 and 2, and (2) mean head in layers 1 and 2. (B) Transmissivity plotted against pre-development discharge by evapotranspiration and seepage to streams and lakes. (C) Transmissivity plotted against mean equilibrium drawdown at pumping locations in layers 1 and 2 . (D) Transmissivity plotted against post-development discharge by evapotranspiration and seepage to streams and lakes. 
A large range of uncertainty is associated with estimates of vertical leakance within the basinfill deposits (BVL). Errors in estimates of vertical leakance result from uncertainty in vertical hydraulic conductivity $\left(\mathrm{K}^{\mathrm{v}}\right)$ and the cumulative thickness of fine-grained deposits. In four simulations, BVL was varied between 0.01 and 100 times baseline values. Pre-development sensitivity plots of BVL versus mean deviation, head, and natural discharge rates are shown in figures 27-a and 27-b. Post-development model- sensitivity plots of BVL versus mean drawdown and natural discharge rates are shown in figures $27-\mathrm{c}$ and $27-\mathrm{d}$.

Model sensitivity to vertical leakance of the volcanic rocks (VVL) was tested by varying this parameter from 0.1 to 100 times baseline values. The ratio of horizontal to vertical hydraulic conductivity $\left(\mathrm{K}^{\mathrm{h}} / \mathrm{K}^{\mathrm{v}}\right)$ in the volcanics varied between runs because transmissivity was held constant. The effective ratios of volcanic vertical anisotropy for each run are listed below:

\begin{tabular}{|c|c|c|c|c|c|}
\hline $\begin{array}{l}\text { Baseline } \\
\text { vertical-leakance } \\
\text { values, times: } \\
\text { Effective }\end{array}$ & 0.01 & 0.1 & 1.0 & 10 & 100 \\
\hline ratio $\mathrm{K}^{\mathrm{h}} / \mathrm{K}^{\mathbf{v}}$ : & 00,000 & 10,000 & 1,000 & 100 & 10 \\
\hline
\end{tabular}

As previously noted, anisotropy ratios of 10,000 or more are not considered plausible but are a side effect of the procedure used in this analysis.

Pre-development model-sensitivity plots of VVL versus mean deviation, head, and natural discharge rates are shown in figures 28 -a and 28-b. Post-development model-sensitivity plots of VVL versus mean drawdown and natural discharge rates are shown in figures 28-c and 28-d.

(5) Lakebed conductance: Baseline lakebed conductance (LC) values tested ranged from a minimum of 100 $\mathrm{ft}^{2} / \mathrm{d}$ (for a $5,000-\mathrm{ft}^{2}$ cell) to a baseline of $100,000 \mathrm{ft}^{2} / \mathrm{d}$ and a maximum of $1,000,000 \mathrm{ft}^{2} / \mathrm{d}$.

Pre-development sensitivity plots of LC versus mean deviation, head, and natural discharge are shown in figures 29-a and 29-b. Post-development model-sensitivity plots of LC versus mean drawdown and natural discharge rates are shown in figures 29-c and 29-d.

(6) Streambed Conductance: Streambed conductance (SC) was varied between two orders of magnitude less than baseline values and two orders of magnitude greater than baseline values. Baseline vertical leakance of streambeds is equal to $0.02 \mathrm{~d}^{-1}$; thus, for a 1,000 -foot by 10 -foot stream reach, the streambed conductance is equal to $0.02 \times 1,000 \times 10=200 \mathrm{ft} / 2$. The range tested for such a reach would have been 2 $20,000 \mathrm{ft}^{2} / \mathrm{d}$.

Pre-development model-sensitivity plots of SC versus mean deviation, head, and natural discharge rates are shown in figures 30-a and 30-b. Post-development model-sensitivity plots of SC versus mean drawdown and natural discharge rates are shown in figures 30-c and 30-d.

(7) Boundary conditions: The portion of the southern boundary of the model near Davis Creek, California, was conceptualized as a stream-line boundary for pre-development conditions. Most data support this thesis (California Department of Water Resources, 1963 and 1982); however, some hydraulic-gradient data suggest subsurface flow out of the basin through interbedded Pliocene and Pleistocene basalts and basinfill deposits in this area. The model was used to investigate the magnitude of potential flux across this boundary. 
PRE-DEVELOPMENT
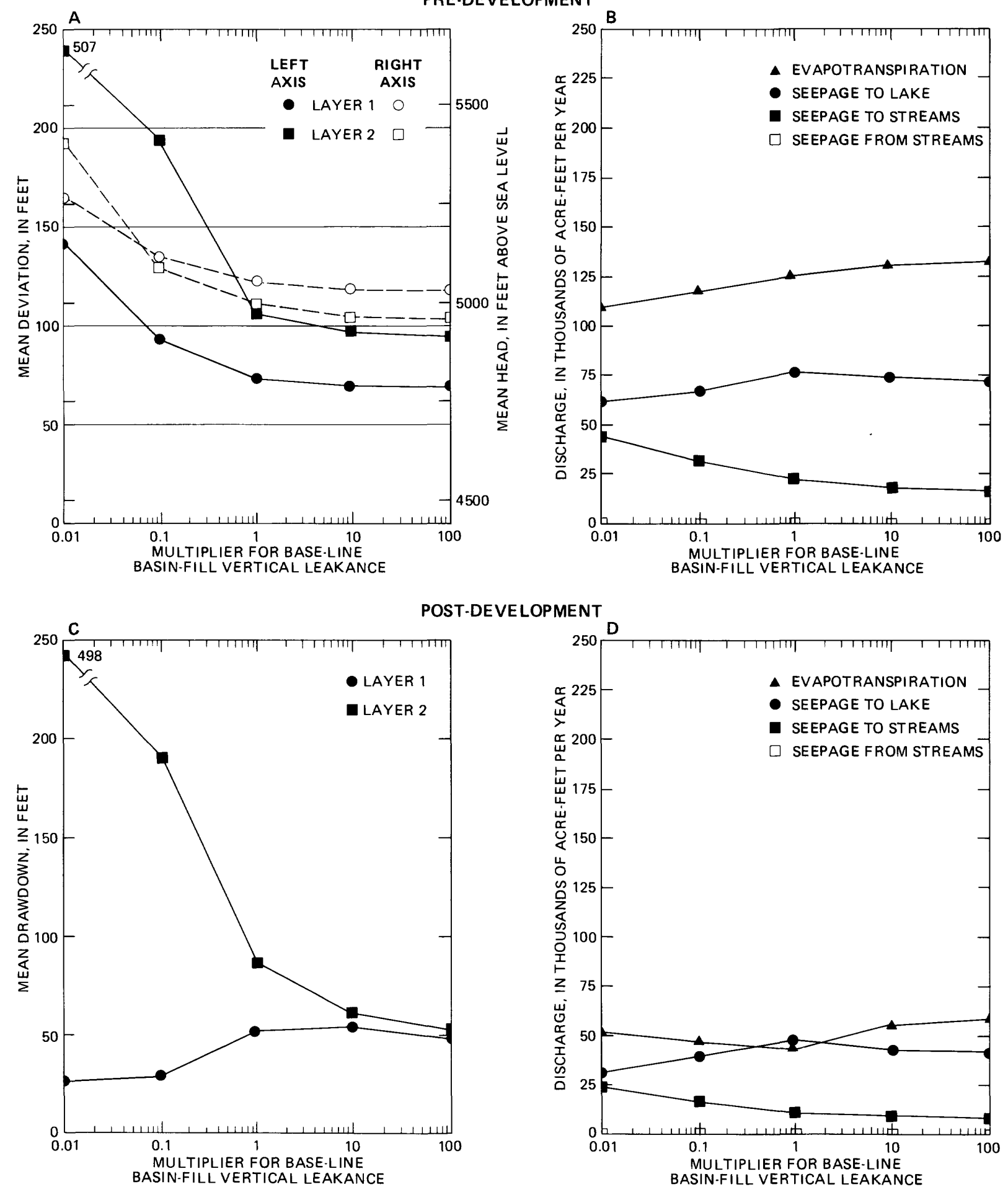

Figure 27.--Sensitivity of simulated heads, drawdown, and discharge to uncertainty in estimates of basin-fill vertical leakance: (A) Vertical leakance plotted against (1) mean deviation of computed from observed pre-development heads in layers 1 and 2, and (2) mean head in layers 1 and 2. (B)Vertical leakance plotted against pre-development discharge by evapotranspiration and seepage to streams and lakes. (C)Vertical leakance plotted against mean equilibrium drawdown at pumping locations in layers 1 and 2. (D)Vertical leakance plotted against post-development discharge by evapotranspiration and seepage to streams and lakes. 
PRE-DEVELOPMENT
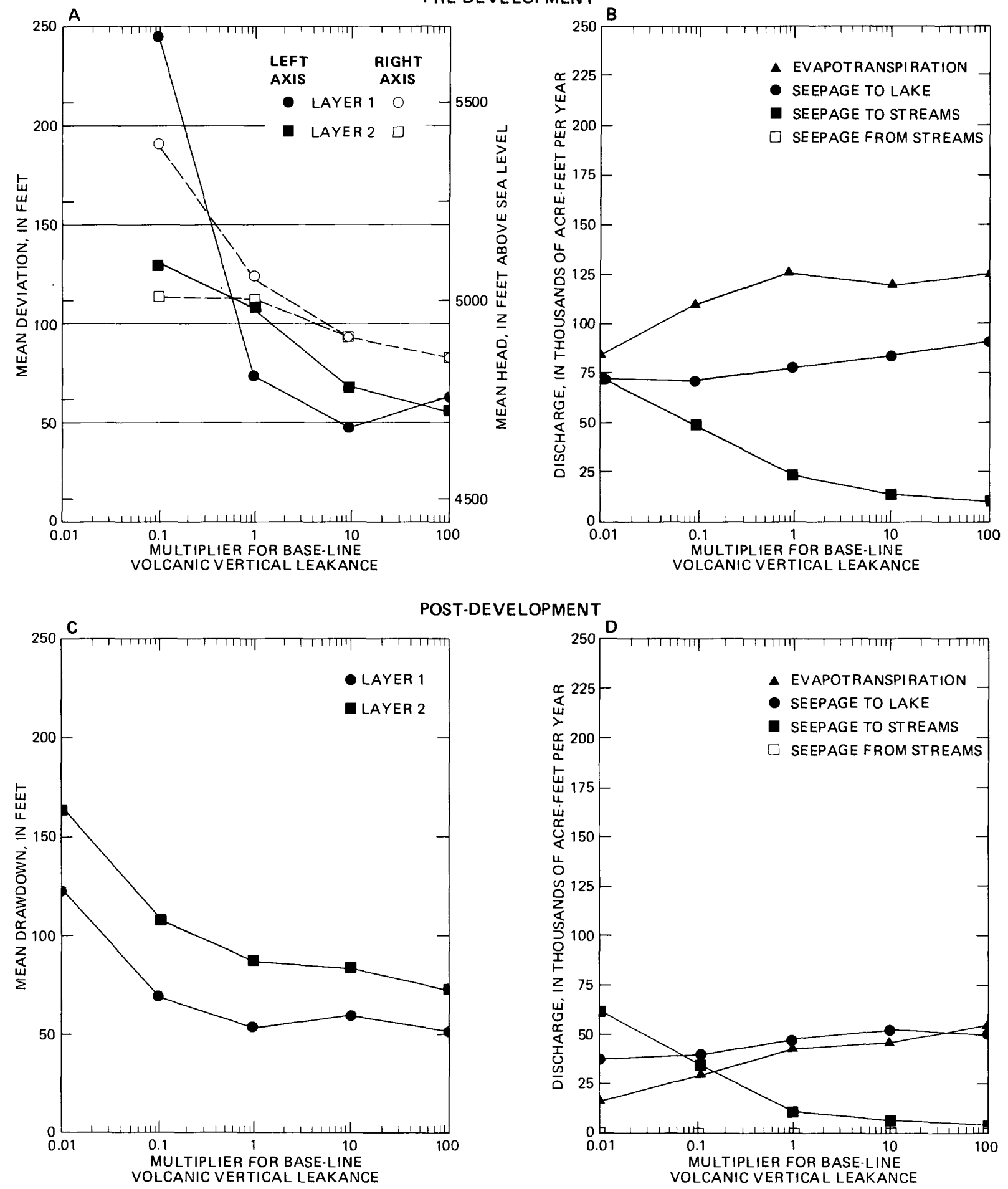

Figure 28.--Sensitivity of simulated heads, drawdown, and discharge to uncertainty in estimates of volcanic vertical leakance: (A)Vertical leakance plotted against (1) mean deviation of computed from observed pre-development heads in layers 1 and 2, and (2) mean head in layers 1 and 2. (B)Vertical leakance plotted against pre-development discharge by evapotranspiration and seepage to streams and lakes.

(C) Vertical leakance plotted against mean equilibrium drawdown at pumping locations in layers 1 and 2.

(D)Vertical leakance plotted against post-development discharge by evapotranspiration and seepage to streams and lakes. 
PRE-DEVELOPMENT
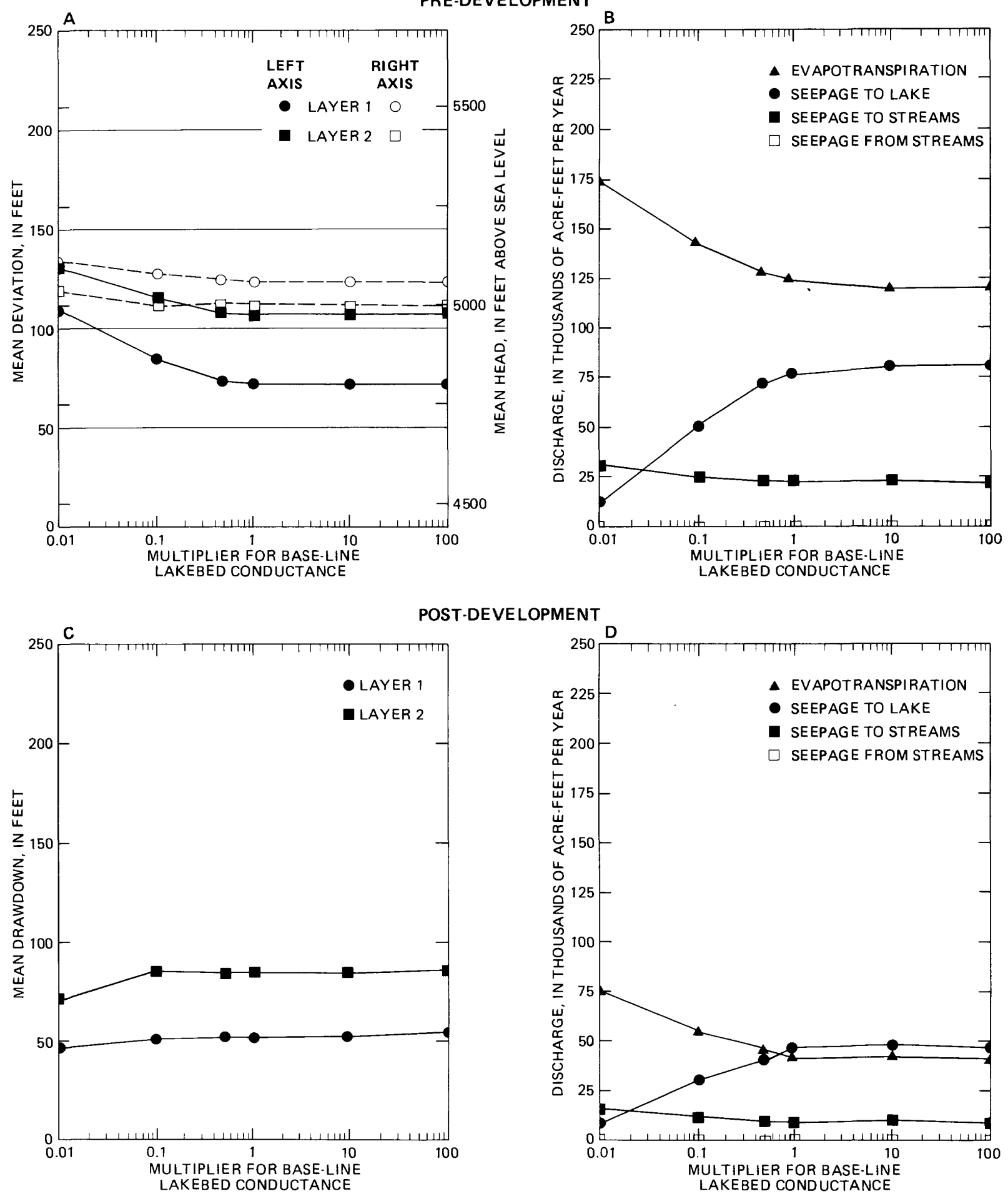

Figure 29.--Sensitivity of simulated heads, drawdown, and discharge to uncertainty in estimates of lakebed conductance: (A) Lakebed conductance plotted against (1) mean deviation of computed from observed pre-development heads in layers 1 and 2, and (2) mean head in layers 1 and 2. (B)Lakebed conductance plotted against pre-development discharge by evapotranspiration and seepage to streams and lakes.

(C) Lakebed conductance plotted against mean equilibrium drawdown at pumping locations in layers 1 and 2. (D) Lakebed conductance plotted against post-development discharge by evapotranspiration and seepage to streams and lakes. 
PRE-DEVELOPMENT
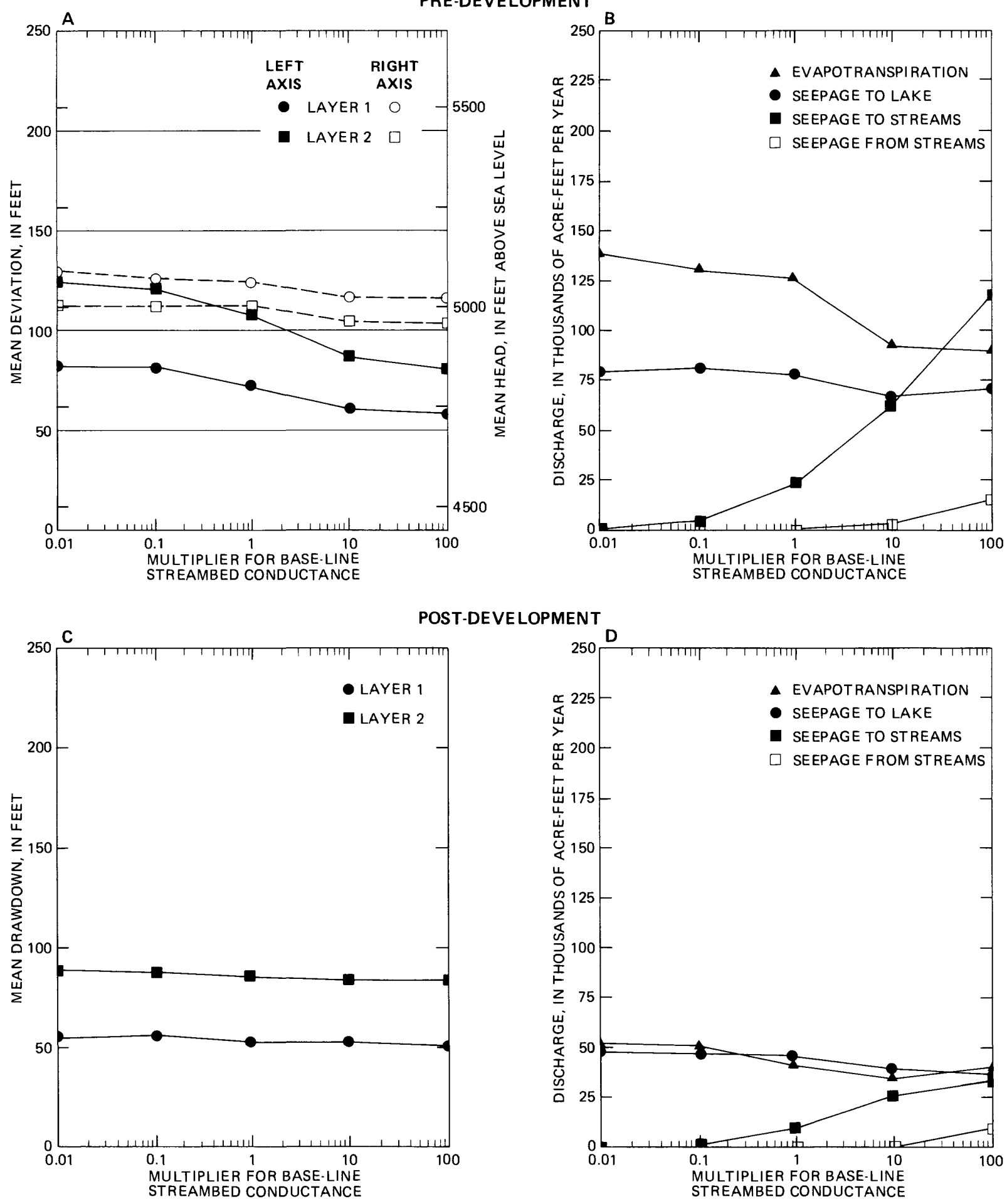

Figure 30.--Sensitivity of simulated heads, drawdown, and discharge to uncertainty in estimate of streambed conductance: (A)Streambed conductance plotted against (1) mean deviation of computed from observed pre-development heads in layers 1 and 2 , and (2) mean head in layers 1 and 2. (B)Streambed conductance plotted against pre-development discharge by evapotranspiration and seepage to streams and lakes.

(C) Streambed conductance plotted against mean equilibrium drawdown at pumping locations in layers 1 and 2. (D) Streambed conductance plotted against post-development discharge by evapotranspiration and seepage to streams and lakes. 
Errors related to selection of inappropriate boundary conditions for a post-development scenario were also investigated because considerable agricultural pumping is concentrated near the assumed noflow boundary south of Davis Creek. Drawdown near the boundary could change--and perhaps has changed--the direction of ground-water flow, invalidating the use of a stream-line, or no-flow, boundary condition.

For these runs, 12 cells (four each in layers 1,2, and 3), shown in figure 11, were designated as a specified-head boundary. The heads specified at the cells were estimated from the hydraulic-head maps shown in figures 14 and 15.

\section{Summary of Results}

The sensitivity of the model, as measured in this study, varied considerably among parameters. Even for a given parameter, the sensitivities of the pre- and post-development models often were different. The relative sensitivities of each model to each parameter are shown in figure 31 and provide a concise, although somewhat subjective, summary of findings from the single-parameter sensitivity analysis.

The pre-development model of the ground-water flow system has large quantities of recharge infiltrating to the saturated zone in the upland volcanic areas and moving downgradient to the discharge areas on the basin floor. The permeability of the aquifer will determine what the hydraulic-head and gradient at any point will be for a given quantity of recharge. For low-permeability rocks, higher heads and a large gradient are required; for high-permeability rocks, lower heads and a small gradient are required. These generalities are complicated somewhat by head-dependent boundaries, such as streams, lakes, or an ET area, but provide a good framework for conceptualizing the Goose Lake flow system. Ground water, after having moved downward and laterally through the volcanics, must move laterally into the basin-fill deposits and then upward to be discharged at the surface by ET and seepage to lakes or streams. The horizontal and vertical permeabilities of the basin-fill deposits also determine the hydraulic head and gradient required for groundwater movement to the discharge areas; however, the heads and gradients are also controlled by features of the discharge area. In the Goose Lake basin, these features include (1) the distribution, root depth, and consumptive-use requirements of phreatophytes; (2) the surface elevation of Goose Lake and the permeability of its bottom; and (3) the elevation and location of streams and the permeability of their beds.

Baseline estimates of recharge, permeabilities, and features of the discharge areas rendered a model of the pre-development system that reproduced observed water levels fairly well in the discharge area but poorly in the upland recharge area. Hydraulic heads in the discharge area were found to be closely controlled by the elevations of the discharge surfaces--that is, the land surface (for ET), stream beds, and the elevation of Goose Lake. Thus, changes in conductance parameters (SC, LC) did not have great influence on hydraulic head. A reduction of lakebed conductance, for example, would shift discharge from seepage to Goose Lake to ET by raising heads a few tenths of an inch over a large area.

Conversely, relatively little discharge occurs from the upland volcanic areas. Computed heads in this area are most sensitive to values of recharge and permeability. Heads computed with baseline parameters were above observed heads at nearly every cell in the model where observed head data were available. Not surprisingly, the pre-development model was found to be very sensitive to reductions in permeability, that is, to restriction of ground-water flow. Model response was consistent in this respect for all parameters describing permeability (BT, VT, BVL, VVL). A good improvement in model fit was generally obtained by increasing any of the permeability parameters up to one order of magnitude; further increases usually resulted in minor improvement or slight degradation of model fit.

The natural rate of seepage to Goose Lake was acutely sensitive to increases in basin-fill transmissivity. Increases in lakebed conductance did not increase seepage to the lake, whereas a ten-fold increase in basin-fill transmissivity caused 50 percent more discharge to Goose Lake. 
PRE-DEVELOPMENT MODEL

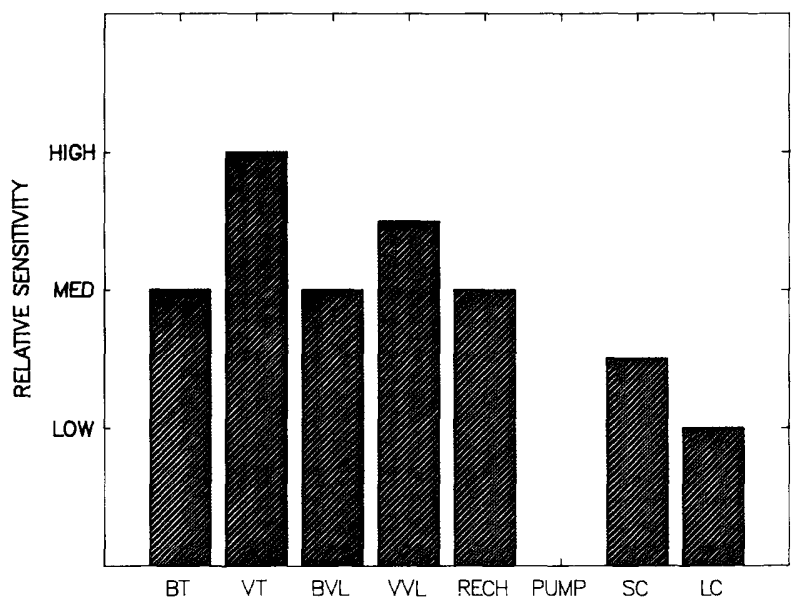

POST-DEVELOPMENT MODEL

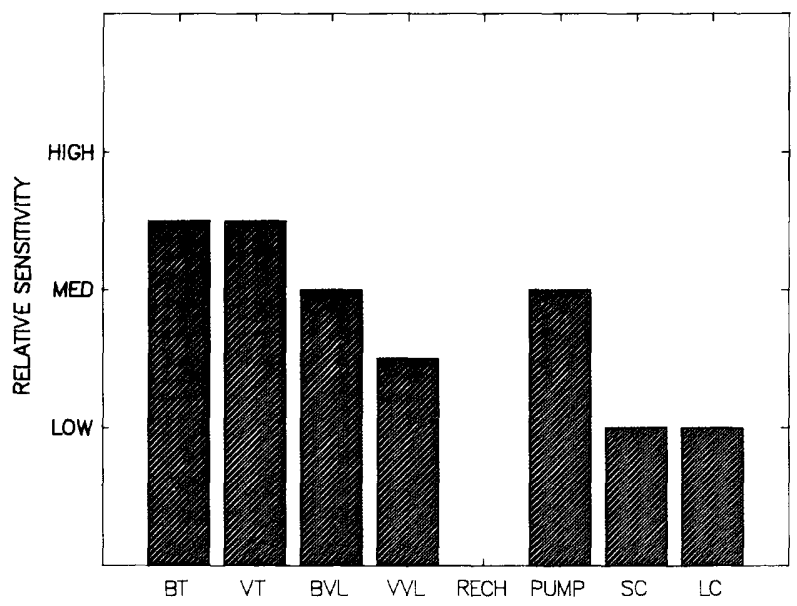

Figure 31.--Relative model sensitivity to uncertainty in selected parameters for pre-development and post-development models. $\mathrm{BL}=$ Basin-fill transmissivity, VT = Volcanic transmissivity, $B V L=$ Basin-fill vertical leakance, $V V L=$ Volcanic vertical leakance, $R E C H=$ Recharge rate, PUMP = Pumping rate, $S C=$ Streambed conductance, $L C=$ Lakebed conductance.

The models showed high sensitivity when vertical leakance of the basin-fill deposits was reduced below baseline values. At reduced values of BVL, flow from the upland recharge areas must occur under much higher hydaulic gradients. Rates of computed natural discharge are relatively insensitive to variation of BVL.

Reducing VVL forces a greater percentage of recharge to flow toward the basin-fill deposits in the uppermost model layer. The vertical anisotropy ratio assumed for the baseline model $(1,000: 1)$ is probably near the maximum reasonable contrast; reduction of VVL resulted in unrealistic simulation results that support this assumption. Increases in VVL allowed more downward movement of ground water in the recharge area, so that horizontal flow could occur through a greater thickness of the aquifer. Computed heads and horizontal hydraulic gradients in layer 1 were considerably lower for VVL values 10 times greater than baseline (compare fig. 32 with fig. 20-a).

The reductions in computed head that accompany reductions in recharge are large in the uplands but diminish on the valley floor. Computed heads in layer 1 of the upland areas were reduced by up to 200 feet when recharge was reduced by 23 percent from the baseline estimate. The simulated potentiometric surface for this simulation is shown in figure 33 (compare with fig. 20-a). The pre-development model has relatively large sensitivity to recharge when sensitivity is compared on the basis of percent change in parameter value versus percent change in computed head. The model is only moderately sensitive, however, to changes in recharge within the range of uncertainty estimated by sensitivity analysis of the DPM-GWR model results.

Substituting a specific head-flux boundary for the no-flow boundary in the pre-development baseline model resulted in 13,000 acre- $\mathrm{ft} / \mathrm{yr}(18 \mathrm{ft} 3 / \mathrm{s})$ of computed subsurface outflow. This simulation only provides an indication of the potential outflow, since the model was not calibrated. 


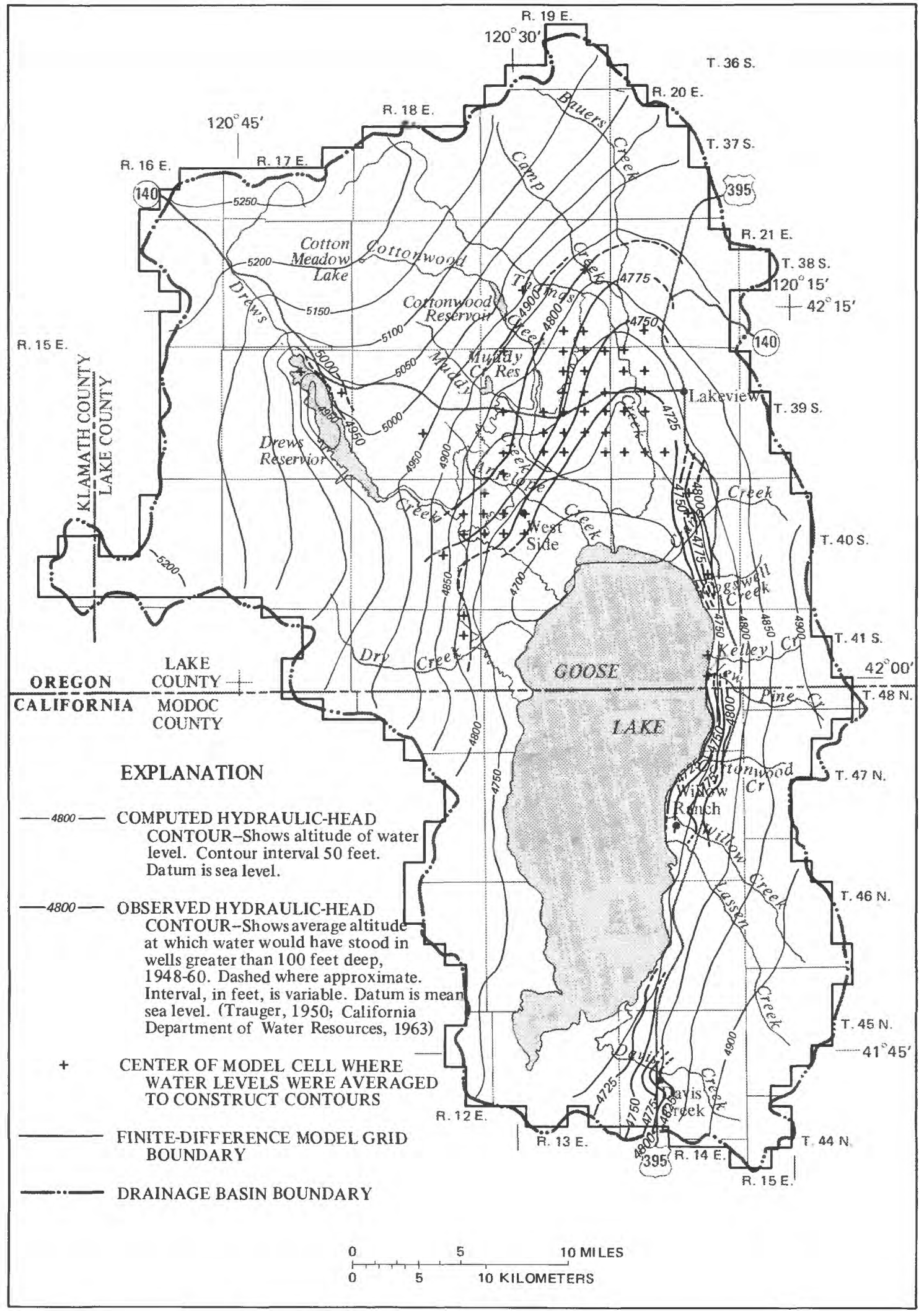

Figure 32.--Simulated plotted against observed pre-development heads in layer 1 when volcanic vertical leakance is equal to base-line values times a factor of 10 . 


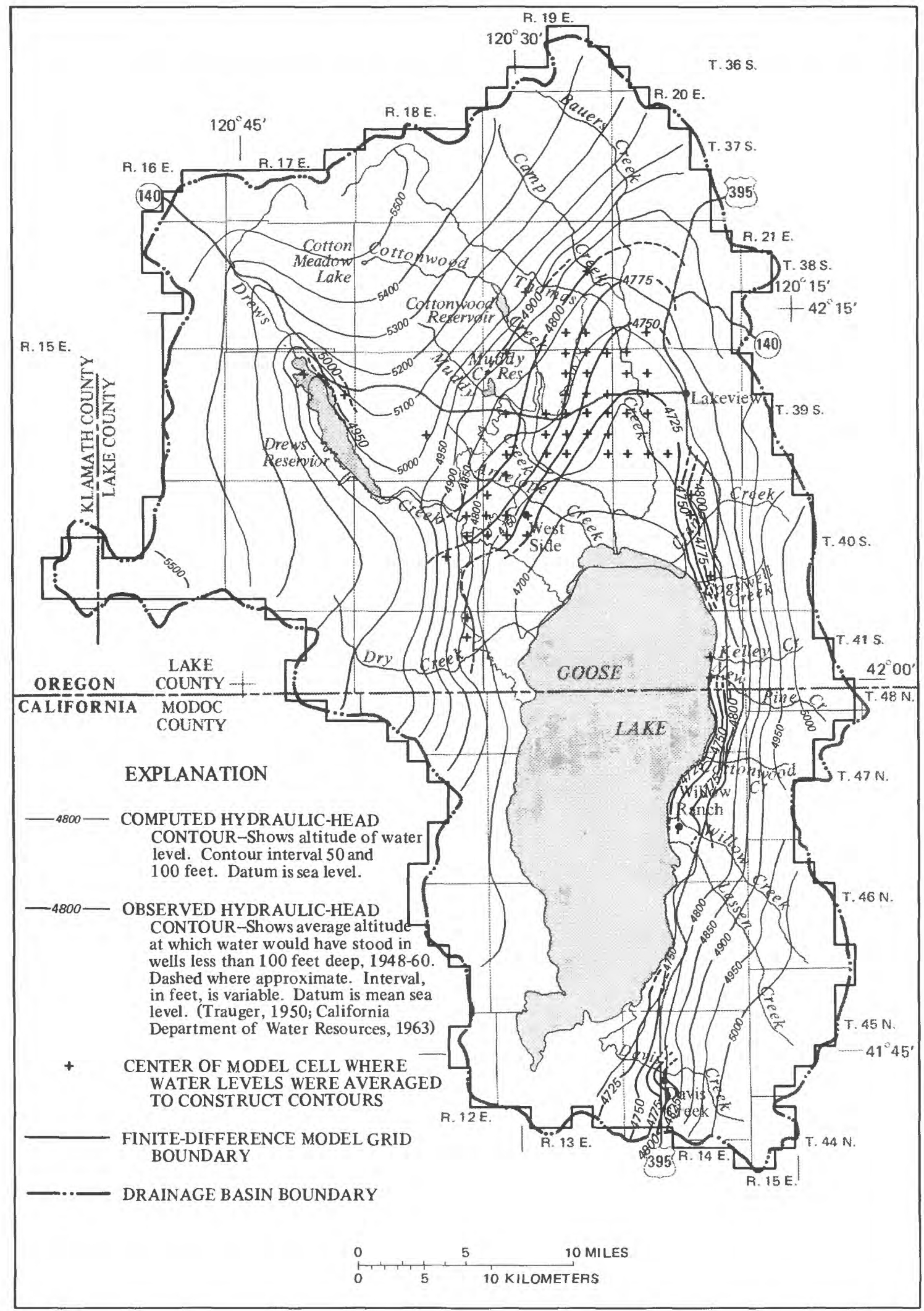

Figure 33.--Simulated plotted against observed pre-development heads in layer 1 when recharge is equal to 77 percent of base-line recharge $(170,000$ acre-feet/year). 
Pumping the system at rates of $34,400,68,800$, and 138,000 acre- $\mathrm{ft} / \mathrm{yr}$ resulted in mean simulated drawdowns of 16,36, and 89 feet in the pumped zone (layer 2) and 6, 17, and 55 feet in the overlying zone (layer 1). Maximum drawdowns simulated were somewhat higher for these withdrawal rates, particularly in layer 2, where they ranged from 50 to 240 feet. The distributions of simulated equilibrium drawdown in layer 2 are shown in figures 34-a, 34-b, and 34-c for the three pumping rates. Mean drawdown and reductions in natural discharge increase linearly with pumping rates (figs. 24-a and 24-b). Of the three principal components of natural discharge, ET is reduced (captured) most readily, followed by seepage to Goose Lake.

Sensitivity analysis of the post-development model revealed that simulated drawdown is very sensitive to reductions of $\mathrm{BT}$ and VT, moderately sensitive to reduction of $\mathrm{BVL}$, and less sensitive to reduction of VVL (fig. 31-b). Compared with a baseline mean drawdown of 89 feet in layer 2 for withdrawals of 138,000 acre-ft/yr, a 70-percent reduction of BT and a 90-percent reduction of VT yielded mean drawdowns of 132 feet and 112 feet respectively. The magnitude and distribution of computed drawdown in layer 2 are shown for these simulations in figures 35 and 36. Maximum computed drawdown for each of these simulations was nearly 450 feet near the most heavily pumped wells on the west side of the valley. Reducing VT apparently causes the volcanics to act as a nearly-impermeable boundary to pumping within the basin-fill deposits. Note in figure 36 how the simulated cone of depression is elongated parallel to the volcanics/basin-fill contact (see pl. 1a for location of contact).

One order-of-magnitude reductions of BVL and VVL resulted in mean drawdowns of 189 feet and 109 feet in layer 2. The magnitude and distribution of computed drawdown in layer 2 are shown for these simulations in figures 37 and 38. Maximum computed drawdowns were approximately 350 feet when BVL was reduced and 250 feet when VVL was reduced. Comparison of computed drawdown for reductions of BT and BVL (figs. 35 and 37) show that, although larger maximum drawdowns occur when BT is reduced, high drawdowns affect a much larger area when BVL is reduced from baseline values. This situation is explained by the restriction of vertical movement of ground water to layer 2 from adjacent layers when BVL is reduced. Under these conditions, a much broader cone-of-depression must form in layer 2 before sufficient flow toward the wells will occur to offset pumping. Within the ranges of uncertainty assumed for them, neither streambed nor lakebed conductance had a significant effect on computed drawdown in the postdevelopment simulations (figs. 29c-29d and 30c-30d).

Results of the boundary-condition sensitivity analysis showed that predicted drawdown in the postdevelopment model was reduced about 40 percent near Davis Creek when ground-water flow was allowed across the southern boundary. The maximum drawdown in the area simulated using no-flow boundary conditions was over 100 feet, whereas allowing inflow across the boundary reduced maximum drawdown to about 60 feet. The computed rate of subsurface inflow (at equilibrium) was 5,900 acre- $\mathrm{ft} / \mathrm{yr}(8.2 \mathrm{ft} / \mathrm{s})$. Comparison of simulated drawdowns in layer 2 (fig. 39) with those computed with a no-flow boundary (fig. 34-c) reveals that the impacts of the boundary are highly localized.

The single-parameter sensitivity analyses of the post-development model showed the ranges of hydrologic impacts (primarily computed drawdown and rates of natural discharge) that result from uncertainties in currently available data for the basin. Minimum reasonable values of horizontal and vertical permeability parameters yielded simulated mean and maximum computed drawdowns nearly twice those computed using baseline values of permeability. Whereas single-parameter sensitivity simulations indicate the effects of individual parameter uncertainty on model results, multiple-parameter simulations show the combined effects of parameter uncertainty on model results.

A multiple-parameter sensitivity simulation was made to estimate the "worse-case" hydrologic impacts that might occur for a level of ground-water development similar to the maximum now (1986) permitted in the basin $(63,000 \mathrm{acre}-\mathrm{ft} / \mathrm{yr})$. To estimate the worse-case impacts, selected system parameters were reduced to their minimum reasonable values. These values are summarized in table 12 . Boundary conditions and some simplifying assumptions in the model also bias model results toward simulation of worst-case impacts. The assumptions and their effects on the model have been discussed in the section, "Limitations on the Use of the Model." 


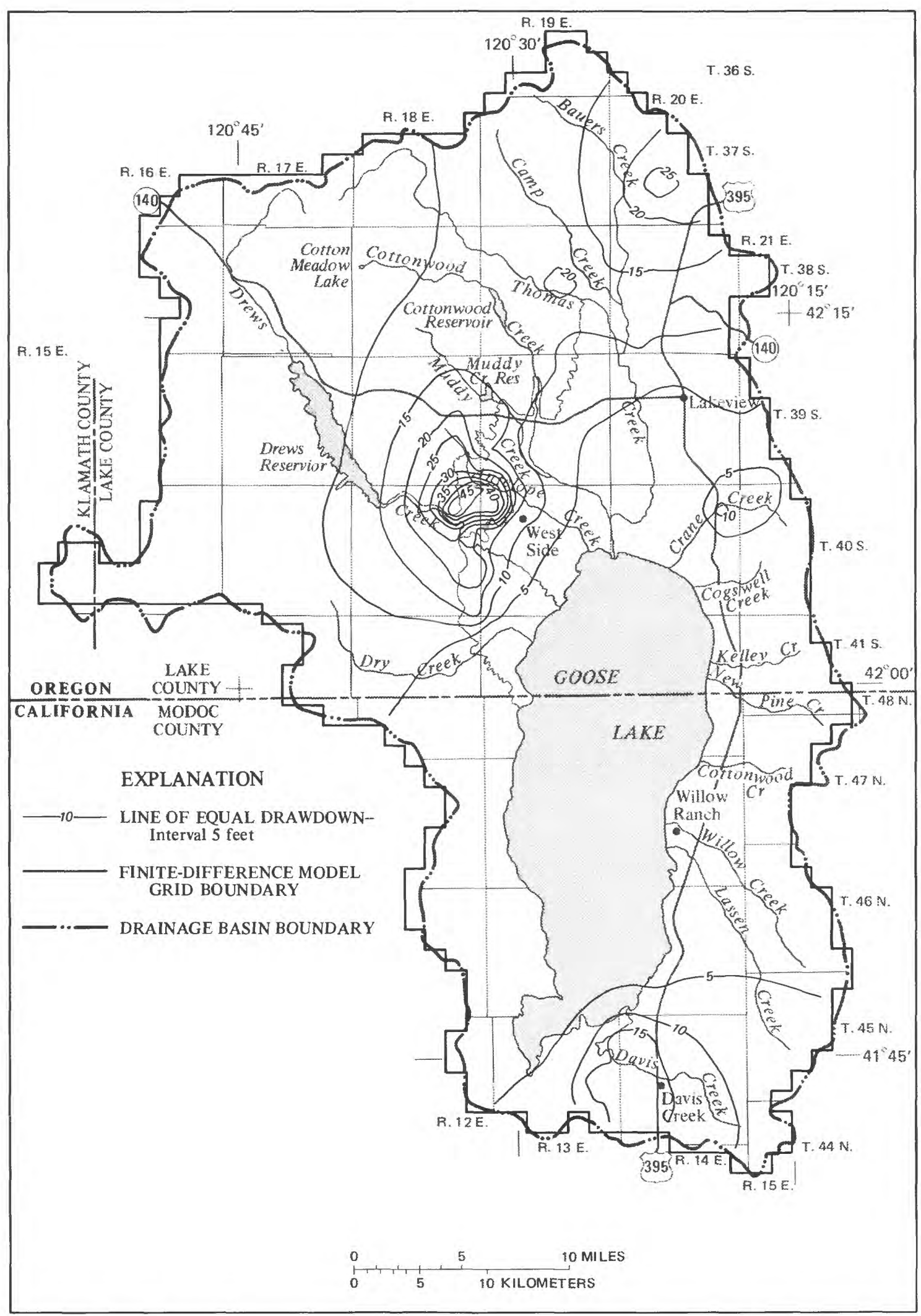

Figure 34a.--Simulated equilibrium drawdown in layer 2 for various pumping rates: 34,400 acre-feet/year. 


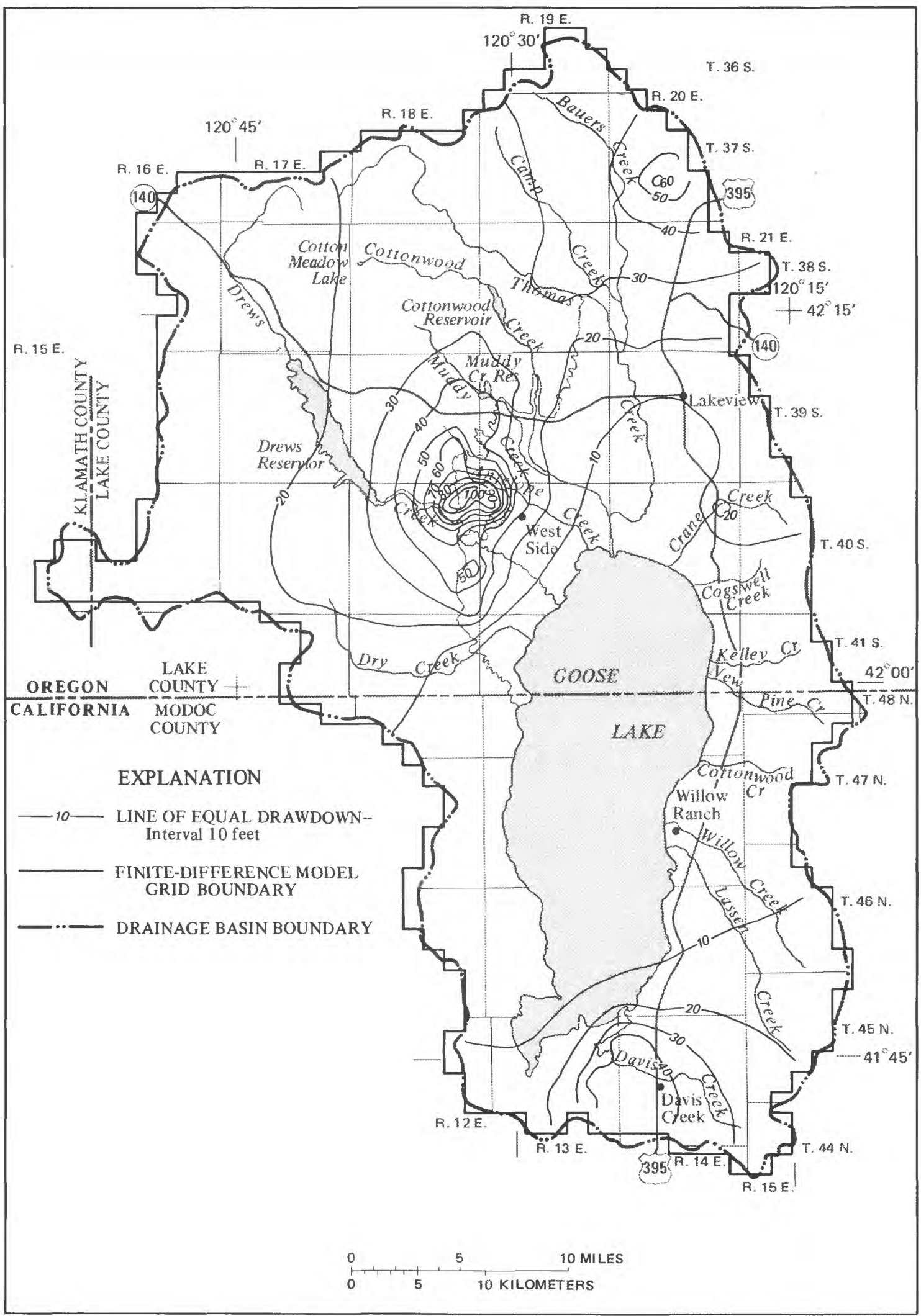

Figure 34b.--Simulated equilibrium drawdown in layer 2 for various pumping rates: 68,800 acre-feet/year. 


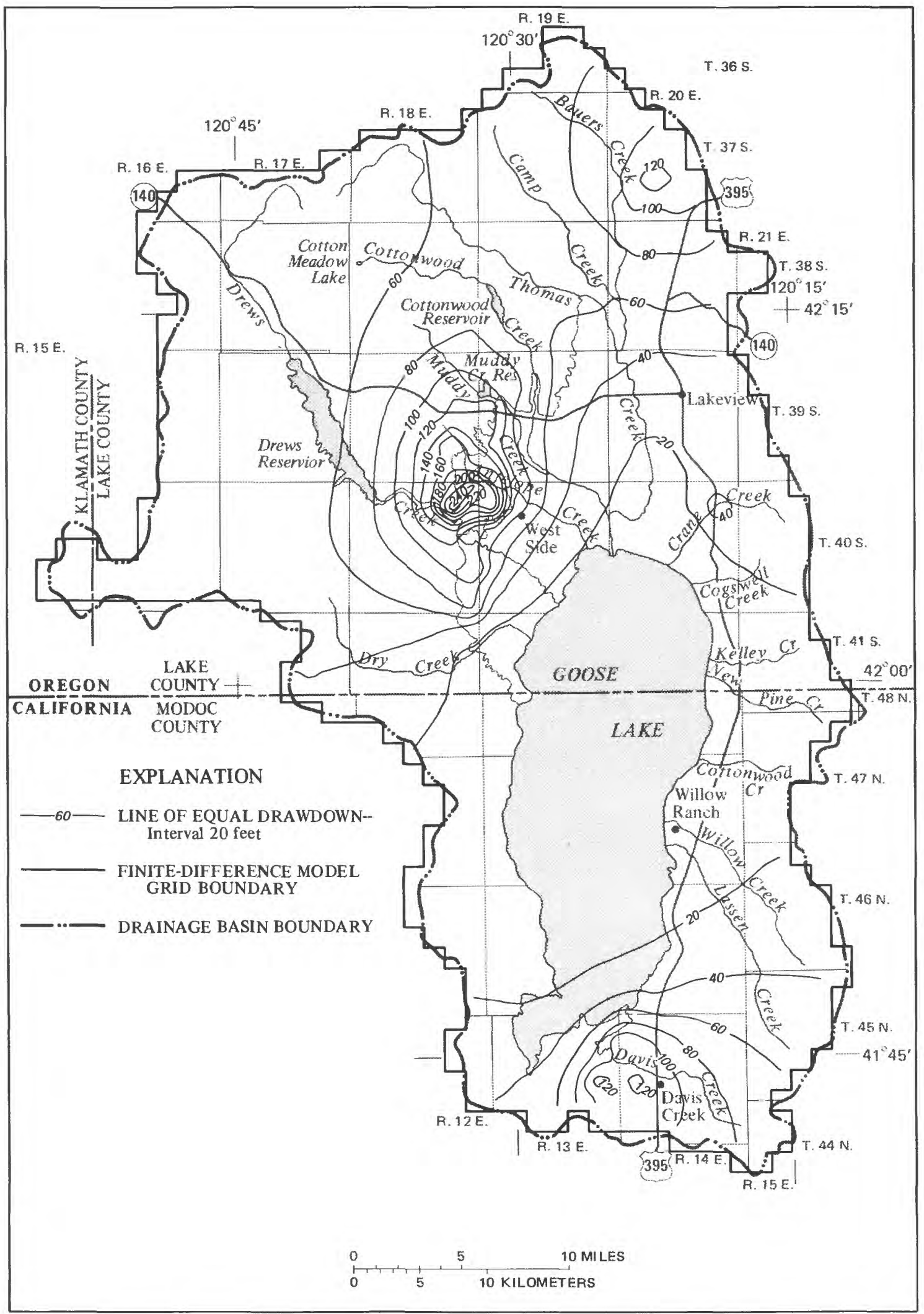

Figure 34c.--Simulated equilibrium drawdown in layer 2 for various pumping rates: 138,000 acre-feet/year. 


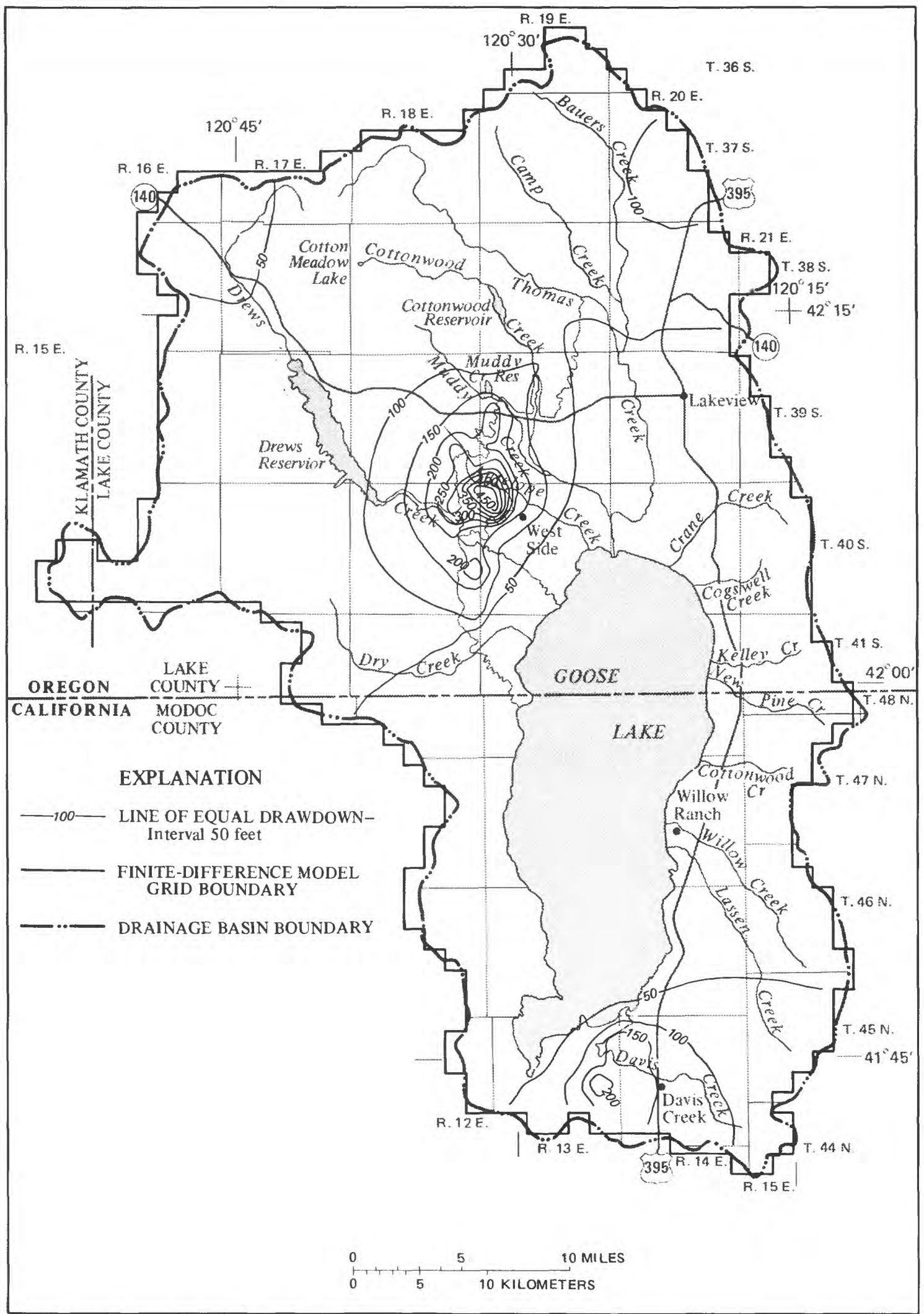

Figure 35.--Simulated equilibrium drawdown in layer 2 when basin-fill transmissivity is equal to base-line values times a factor of $\mathbf{0 . 3}$. 


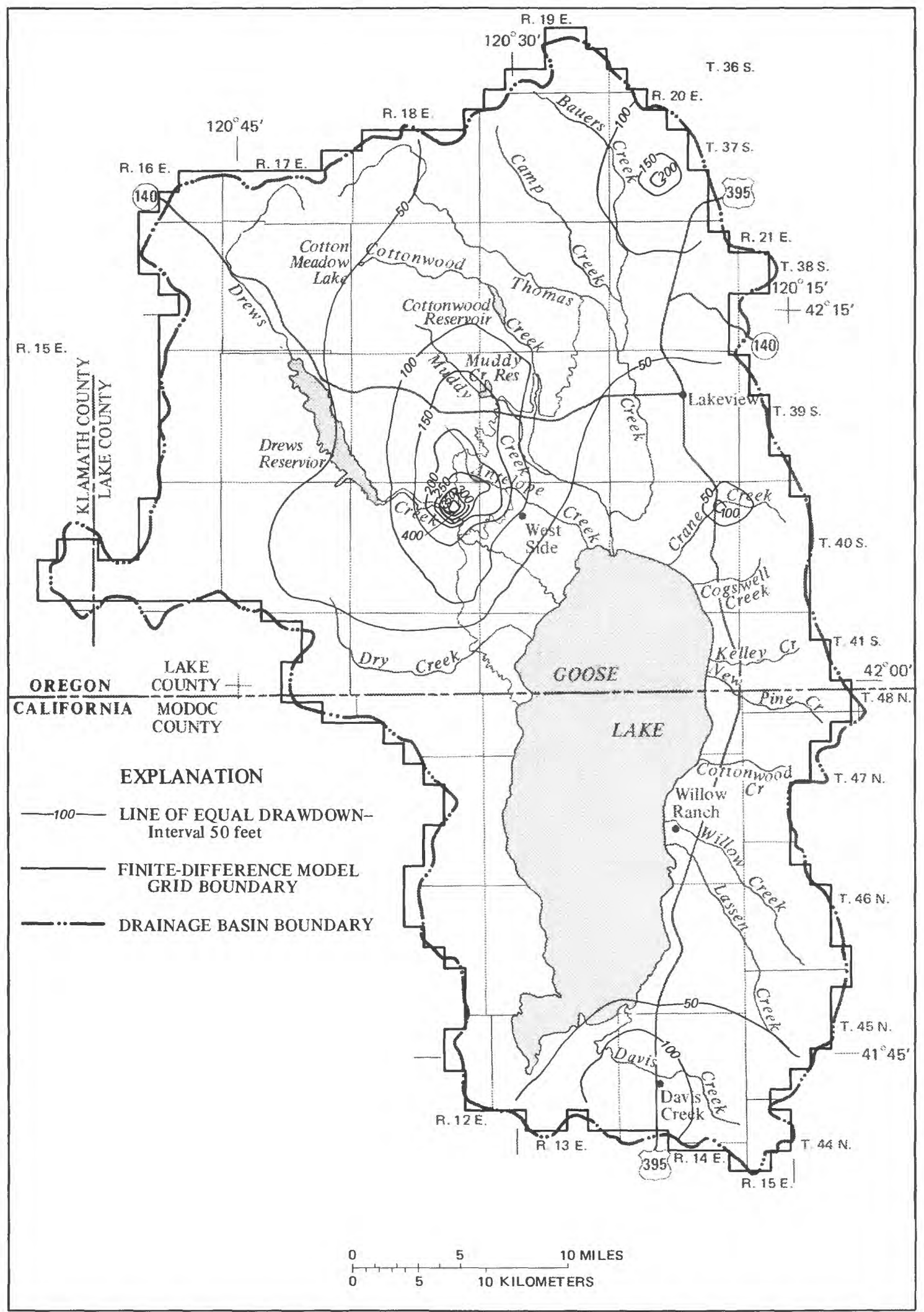

Figure 36.--Simulated equilibrium drawdown in layer 2 when volcanic transmissivity is equal to base-line values times a factor of 0.1 . 


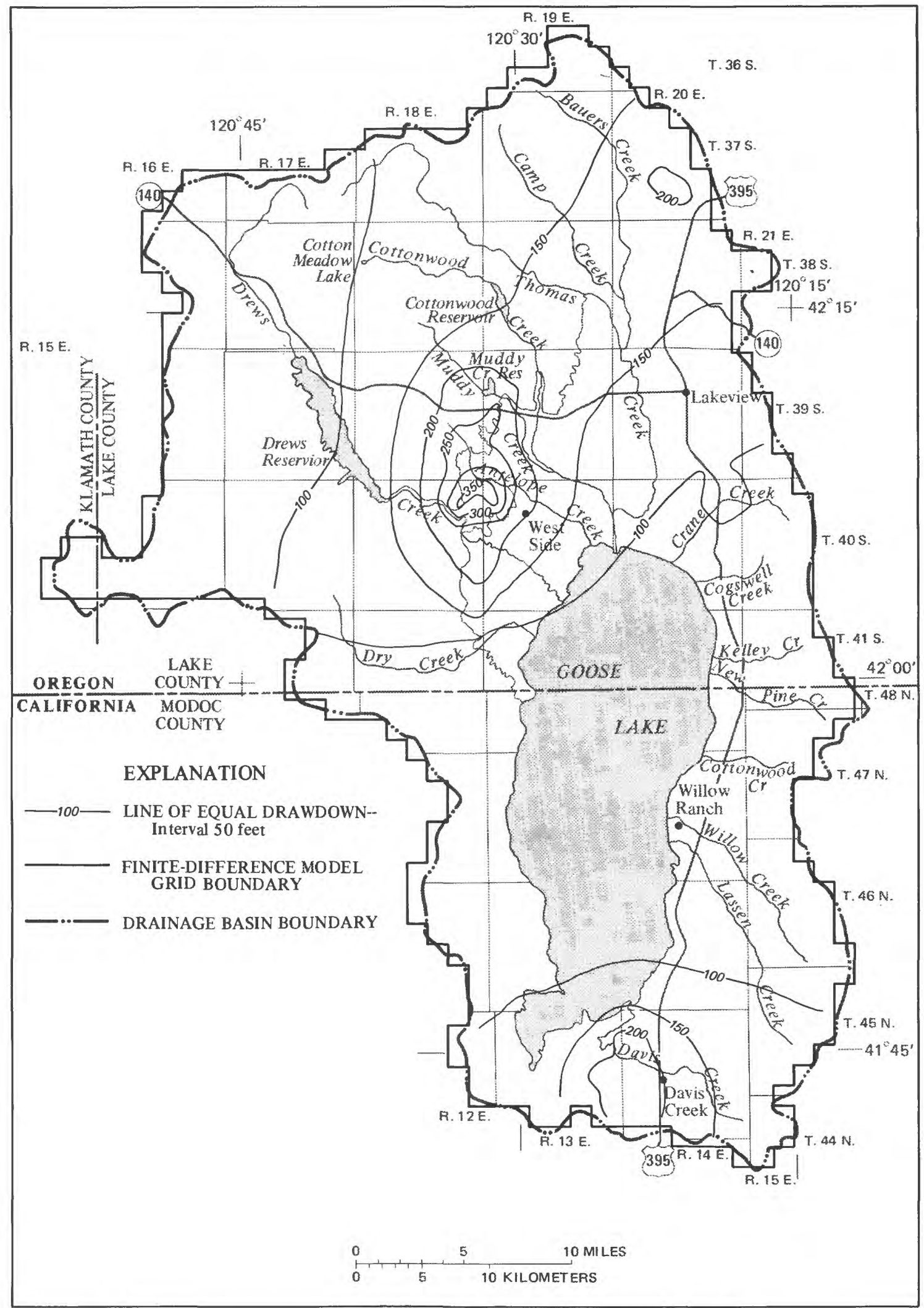

Figure 37.--Simulated equilibrium drawdown in layer 2 when basin-fill vertical leakance is equal to base-line values times a factor of 0.1 . 


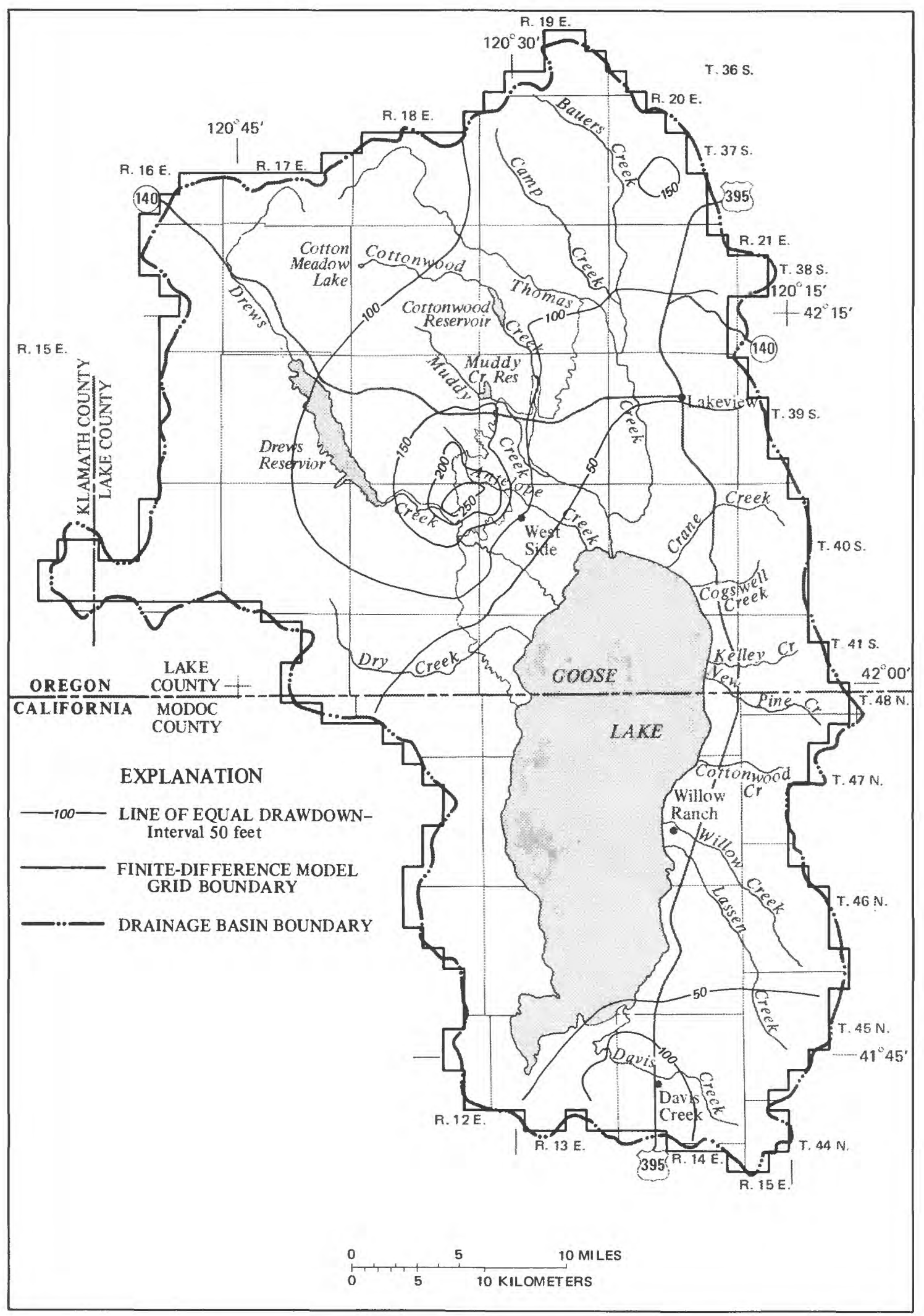

Figure 38.--Simulated equilibrium drawdown in layer 2 when volcanic vertical leakance is equal to base-line values times a factor of 0.1 . 


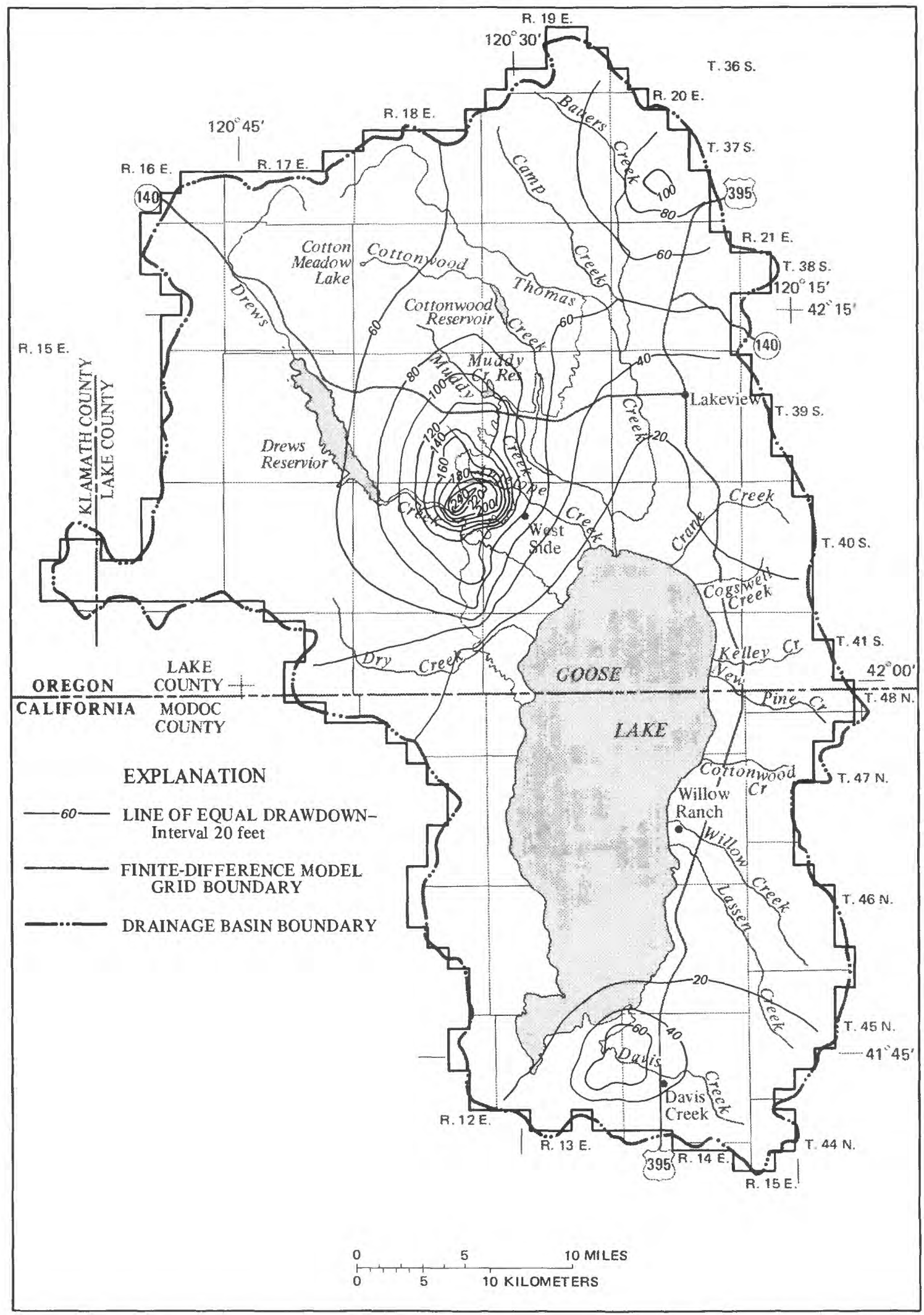

Figure 39.--Simulated equilibrium drawdown in layer 2 when pumpage is eight times 1985 rates and specified-head boundary conditions are used near Davis Creek. 
Table 12.--Estimates of minimum system-parameter values for a worst-case hypothetical simulation

Parameters Minimum value

Basin-fill

$\begin{array}{ll}\text { Transmissivity } & \text { Baseline } \times 0.3 \\ \text { Vertical leakance } & \text { Baseline } \times 0.1\end{array}$

Volcanics

Transmissivity Baseline $\times 0.3$

Vertical leakance $\quad$ Baseline $\times 0.1$

Recharge

Baseline $\times 0.77$

Streambed conductance $\quad$ Baseline $\times 0.1$

Lakebed conductance $\quad$ Baseline $\times 0.1$

Simulation of the pre-development flow system is poor using this combination of parameters. The calculated hydraulic-heads in layers 1 and 2 were far above observed heads; the mean deviations in layers 1 and 2 were 169 feet and 255 feet, respectively, for the worst-case model, compared to 73 feet and 109 feet for the baseline model.

Pumping-induced drawdown in layer 2 for the worst-case model is shown in figure 40. Mean drawdown in layer 2 was 113 feet, but maximum drawdown equaled 250 feet. This drawdown compares with a mean drawdown of 36 feet and maximum of 100 feet in layer 2 for the baseline model with equivalent pumping stress (compare fig. 40 with fig. $34-\mathrm{b}$ ).

\section{Transient Effects of Pumping}

As previously discussed, the time-dependent dynamics of the flow-system were not considered in the sensitivity analysis. The drawdowns computed during this analysis were the equilibrium drawdowns that would occur when pumping withdrawals were balanced by capture of natural discharge. The dynamics of many ground-water systems are such that long periods of time are required before equilibrium can be reestablished. The rate at which the hydrologic system can reach a new equilibrium depends on the rate at which natural discharge can be captured (Bredehoeft and others, 1982, p. 56). Adequate management of groundwater resources sometimes requires that the response time of hydrologic effects be known.

A transient simulation of the Goose Lake basin was made to estimate the time required for the system to reach a new equilibrium if a major pumping stress were imposed. Boundary conditions and system parameters were identicai to those used in the baseline models, and simulated heads from the pre-development baseline model results were used as initial conditions. The storage coefficients assumed for this simulation are listed in table 13. 


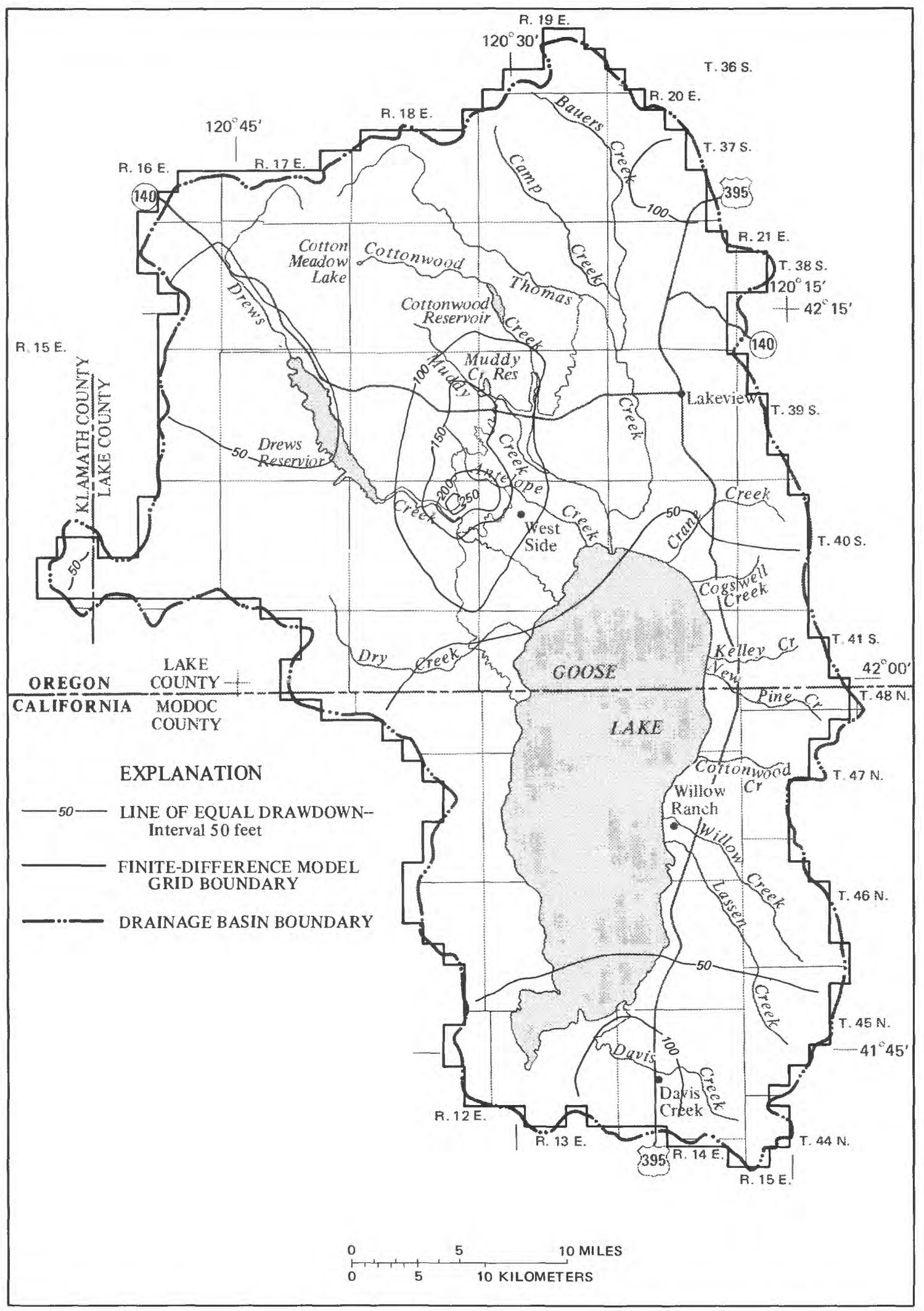

Figure 40.--Simulated equilibrium drawdown in layer 2 using minimum (worst-case) values of model parameters. 


Model layer $\frac{\text { Storage coefficient (dimensionless) }}{\text { Basin-fill }}$

\begin{tabular}{llcc}
\hline 1 & $1 \times 10^{-1}$ & $1 \times 10^{-1}$ \\
2 & $7 \times 10^{-4}$ & $1 \times 10^{-4}$ \\
3 & $2 \times 10^{-3}$ & $4 \times 10^{-4}$ \\
4 & 1 & $2 \times 10^{-3}$ \\
\hline
\end{tabular}

1Basin-fill deposits are not represented by cells in layer 4.

Three hundred years of pumping 68,800 acre-ft/yr (four times the 1985 pumpage) were simulated with pumping wells located as they were in 1985 (pl. 1b). Results of the simulation are summarized in figures 41$a$ and 41-b. Rates of simulated storage depletion and water-level decline tapered off rapidly after 10 years of pumping, and the system had essentially reached a new equilibrium within 100 years. Location of pumping wells in and near the discharge area on the valley floor made it possible for moderate drawdowns to capture enough natural discharge to balance pumping in a relatively short time. At equilibrium, the source of water to wells was mostly reduced ET ( 60 percent), followed by reduced seepage to Goose Lake ( 30 percent), and reduced discharge to streams (10 percent).

Higher storage coefficients would extend the time required for the system to attain a new equilibrium by allowing more pumpage to be derived from ground-water storage for each foot of drawdown. No other storage coefficients were used to test the effects of storage coefficient on re-equilibriation times.

\section{CONCLUSIONS}

The primary objective of this study was to describe the ground-water hydrology of the Goose Lake basin as completely as possible on the basis of existing data and easily collected data. Quantitative estimates of recharge, discharge, and hydraulic characteristics of water-bearing rocks in the basin were sought wherever possible. The second goal of the study was to determine whether available data allow a description of the system that is useful to ground-water managers and planners. A simulation-model analysis of the basin was used to evaluate the description, or conceptual model, of the system. The model analysis included simulations of both pre- and post-development conditions using baseline estimates of system parameters, single- and multiple-parameter sensitivity analyses, and simulation of the time-dependent response of the basin to pumping.

General conclusions of this study are as follows:

(1) Data currently available for the Goose Lake basin are adequate for formulation of reasonable conceptual and mathematical models of the ground-water flow system.

(2) Single-parameter sensitivity analysis of an uncalibrated mathematical model can be used to help establish uncertainties in system parameters and model reliability.

(3) Ground-water development in the basin will be limited to the amount of water that can be diverted, by wells, from natural discharge by evapotranspiration and seepage to Goose Lake within the constraints of keeping water-level declines and other negative hydrologic impacts within tolerable levels. 


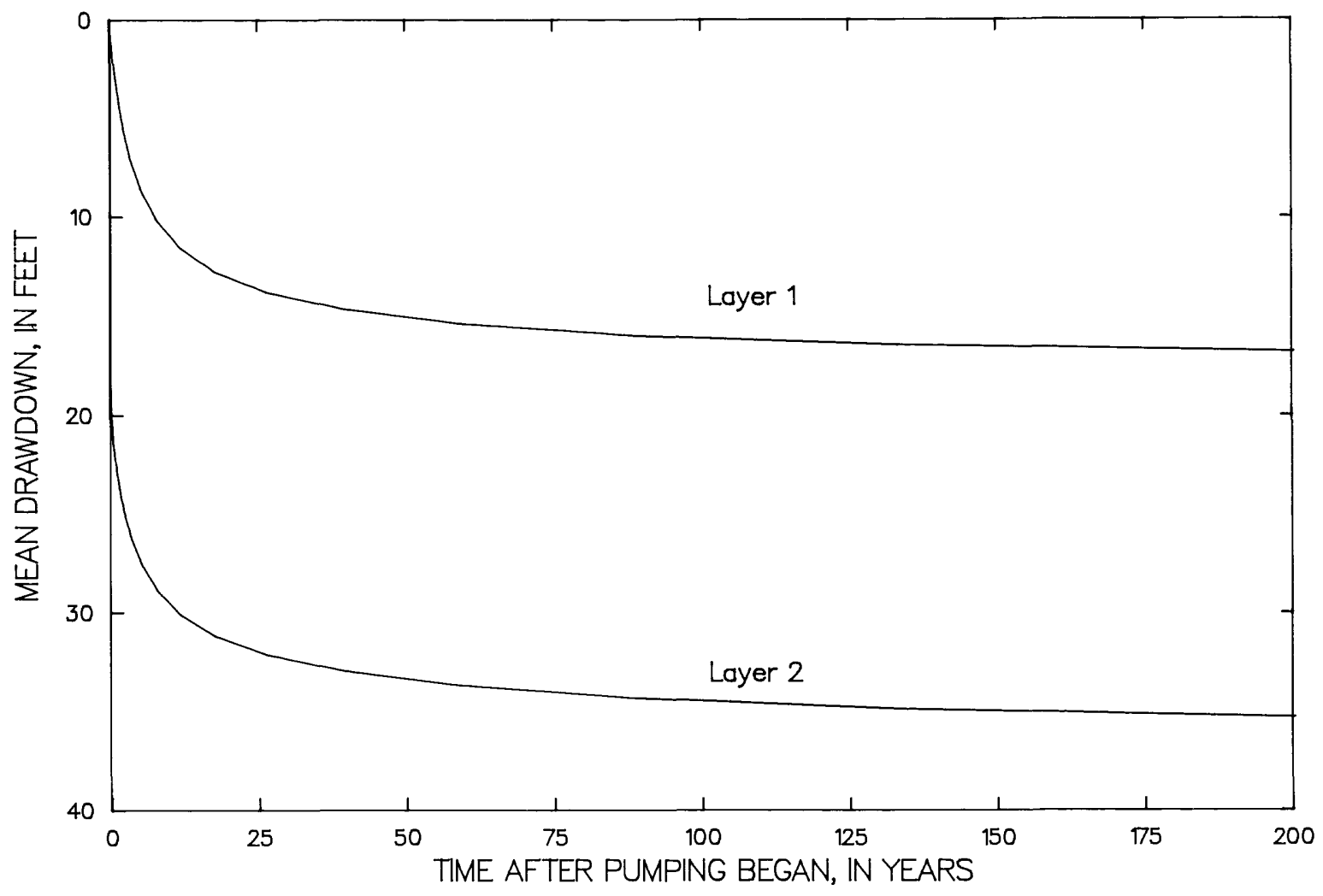

Figure 4 la.--Results of 300-year transient simulation of pumping equal to 68,800 acre-feet/year: Hydrograph of mean computed drawdown in layers 1 and 2 .

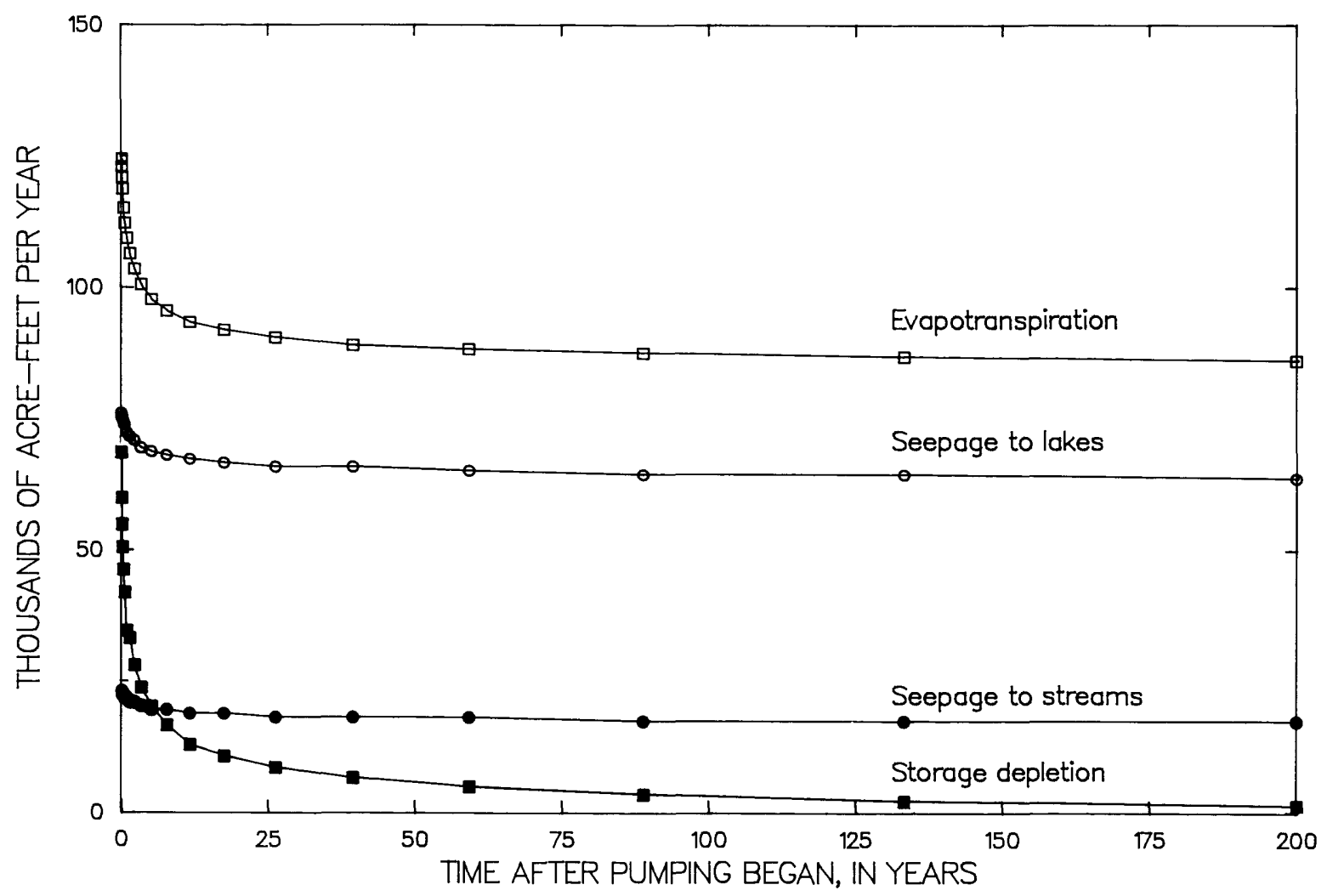

Figure 41 b.--Results of 300 -year transient simulation of pumping equal to 68,800 acre-feet/year: Computed rates of natural discharge and storage depletion with time. 
(4) Multiple-parameter sensitivity simulations using the uncalibrated model with minimum values of permeability and conservative boundary conditions can be used to estimate "worst-case" hydrologic impacts for a given level of ground-water development.

(5) Additional data collection would be required to increase model reliability, primarily because currently available data are not adequate for calibration of a transient model of the flow system.

Results of the pre-development baseline simulation increase confidence levels in estimates of recharge and system parameters and in the concepts of boundaries to the flow system. The baseline model is least accurate in reproducing observed hydraulic heads in the upland areas and is quite sensitive to uncertainties in the hydraulic characteristics of the volcanic rocks underlying these areas. Model results suggest the following possibilities: (1) the volcanics as a unit are more permeable than originally thought, (2) estimated recharge is too high, or (3) both of the above. The hydraulic properties of the upland volcanics have little impact on hydraulic heads in the basin-fill deposits when the system is not stressed by pumping. Postdevelopment model simulations showed, however, that if the volcanics have significantly lower permeability than the basin-fill deposits, pumping stress near the volcanic/basin-fill contact causes much greater drawdown. Development of an accurate model for predicting the effects of development, therefore, will require better estimates of the hydraulic characteristics of the volcanics.

Ground-water discharge under natural conditions was mostly by ET and seepage to Goose Lake and streams. The estimated water budget for Goose Lake indicates that an average of 130,000 acre-ft/yr of ground water discharges to the lake. Natural ground-water discharge by ET and seepage to streams could not be accurately estimated from available data, but their combined discharge would have been approximately 90,000 acre-ft/yr if annual recharge were 220,000 acre-ft. Baseline model results indicated that most ground-water discharge was by ET ( 124,000 acre-ft/yr), followed by seepage to Goose Lake (76,000 acre-ft/yr), and seepage to streams $(23,000 \mathrm{acre}-\mathrm{ft} / \mathrm{yr})$. Computed discharge rates under pre-development conditions are most strongly influenced by the transmissivity of the basin-fill deposits and the elevation of the discharge surfaces (land surface and stage of Goose Lake) and not by lakebed or streambed conductances. Model parameters could be adjusted to allow more seepage to Goose Lake (to match water-budget estimates) and to reduce ET; predevelopment model-sensitivity analysis shows that this could be accomplished by a reasonable increase in basin-fill transmissivity.

Post-development sensitivity analysis shows, however, that the magnitude and extent of equilibrium drawdown is not strongly related to the proportions of natural discharge by ET and seepage to Goose Lake. Hydraulic characteristics of the basin-fill play a much larger role in determining the model response to pumping stress. Vertical leakance of the basin-fill deposits was found to be a critical parameter for predicting the hydrologic effects of pumping. Basin-fill transmissivity and the hydraulic characteristics of the volcanics are also important. Of the hydraulic characteristics, basin-fill transmissivity is known most accurately and represents one of the smallest sources of error in the post-development model.

Pre- and post-development models indicated that baseline estimates of hydraulic characteristics were underestimated in general. If so, water-level declines predicted by the baseline model would be greater than might actually occur. Computed declines were also biased toward unrealistically large values by using noflow boundaries at ground-water divides. Near Davis Creek this practice was found to have significant, although localized, effects on simulated drawdown. Sensitivity tests of individual parameters showed that hydraulic characteristics equal to minimum reasonable values resulted in computed drawdowns that exceeded those estimated using the baseline values by as much as 200 percent.

The maximum equilibrium drawdown for pumping nearly 70,000 acre-ft/yr was estimated by a worstcase, multi-parameter simulation in which system parameters were reduced to minimum reasonable values. The maximum expected drawdown for the worst-case scenario was 250 feet--more than 300 percent greater than the maximum drawdown predicted using baseline parameters. 
The time-dependent response of the system was simulated using assumed storage-coefficient values and simulating a 300-year period of pumping of nearly 70,000 acre-ft/yr. This simulation showed that, when pumping is concentrated in and near the discharge area--as it is in the Goose Lake basin, the system can reach a new equilibrium relatively quickly. For assumed values of storage coefficient, new equilibrium conditions were reached within 100 years when pumping discharge was balanced by reductions of ground-water ET and seepage to lakes and streams.

The sensitivity analysis performed in this study showed that the hydrologic impacts of ground-water withdrawals in the basin are, and will be, most closely related to the hydraulic conductivity, thickness, and extent of basin-fill deposits. Well-yield and lithologic data from drillers' reports provided the basis for the baseline estimates of transmissivity and vertical leakance made in this study. Considerable refinement of these estimates could be made using data from a program involving drilling, surface and borehole geophysical surveys, and aquifer testing. Aquifer test data from wells near the volcanic/basin-fill contact on the west side of the valley would be particularly useful for determining the hydraulic connection between the upland recharge areas and the basin-fill deposits.

The geohydrology of the upland volcanic areas is a weak point of the current conceptual model of the basin. A geologic reconnaissance of the uplands might provide a rationale for differentiation of the geologic units on the basis of hydraulic characteristics and a better understanding of hydrogeologic boundaries to ground-water flow.

Historical pumping and water-level data will be required to support a calibration of a numerical model. The existing water-level monitoring network of five wells in Oregon and six wells in California is not adequate to support a model-calibration procedure, but with moderate expansion it could provide a good early-warning system for water-level declines. If persistent water-level declines were observed, the network could be expanded further to obtain detailed water-level records areally and with depth. Records of electricpower consumption for irrigation have been stored on computer since 1981 by the Surprise Valley Electrification Corporation and may be available for reconstruction of historical pumping data. 


\section{REFERENCES}

Bauer, H. H., and Vaccaro, J. J., (1987), Documentation of a deep-percolation model for estimating groundwater recharge: U.S. Geological Survey Open-File Report 86-536, 180 p.

Bear, Jacob, 1979, Hydraulics of groundwater: New York, McGraw-Hill, 569 p.

Bigelow, B. B., Goodel, S. A., and Newton, G. D., 1984, Water withdrawn for irrigation in 1980 on the Snake River Plain, Idaho and eastern Oregon: U.S. Geological Survey Open-File Report 84-434, 2 sheets.

Bredehoeft, J. D., Papadopulos, S. S., and Cooper, H. H., 1982, Groundwater: The water-budget myth, in Scientific basis of water- resource management, Studies in Geophysics: Washington, D.C., National Academy Press, p. 51-57.

Brutsaert, W. H., 1982, Evaporation into the atmosphere--Theory, history, and applications: Dordrecht, Holland, D. Reidel Co., 299 p.

California Department of Water Resources, 1963, Northeastern counties ground-water investigation: State of California, Department of Water Resources, Bulletin 98.

California Department of Water Resources, 1982, Northeastern counties ground water update: State of California, The Resources Counties Agency, Department of Water Resources, Northem District, $86 \mathrm{p}$.

Daum, R. M., 1966, Goose Lake water-quality control policy, Basic data report: State of California, The Resources Agency, Regional Water Quality Control Board, Central Valley Region, 158 p.

Diamond, J., and Williamson, A. K., 1983, A summary of ground-water pumpage in the Central Valley, California, 1961-77: U.S. Geological Survey Water-Resources Investigations Report 83-4037, 70 p.

Durbin, T. J., Kapple, G. W., and Freckleton, J. R., 1978, Two-dimensional and three-dimensional digital flow models of the Salinas Valley ground-water basin, California: U.S. Geological Survey WaterResources Investigations Report 78-113, 134 p.

Freeze, R. A., and Cherry, J. A., 1979, Groundwater: Englewood Cliffs, New Jersey, Prentice-Hall, Inc., $603 \mathrm{p}$.

Frenzel, S. A., 1985, Comparison of methods for estimating ground-water pumpage for irrigation: Ground Water, Journal of National Water Well Association, v. 23, n. 2, p. 220-226.

Gay, T. E., and Aune, Q. A., 1958, Geologic map of California, Alturas Sheet: California Division of Mines, $1: 250,000$.

Harding, S. T., 1965, Recent variations in the water supply of the western Great Basin: University of California Archive Services, Report Number 16, 230 p.

Helm, D. C., 1978, Field verification of a one-dimensional mathematical model for transient compaction and expansion of a confined aquifer system: Proceedings of the specialty conference on verification of mathematical and physical models in hydraulic engineering, ASCE/College Park, Maryland, August 911, 1978, p. 189-196.

Jacobs, J., 1909, Central Oregon investigations--Irrigation possibilities, Lakeview District: Unpublished consulting report held by California Department of Water Resources, Red Bluff, California. 
McClelland, E. J., 1963, Aquifer test compilation for the San Joaquin Valley, California: U.S. Geological Survey Open-File Report, 40 p. (revised 1966).

McDonald, M. G., and Harbaugh, A. W., 1984, A modular three-dimensional finite-difference ground-water flow model: U.S. Geological Survey Open-File Report 83-875, 528 p.

McKee, E. H., Duffield, W. A., and Stern, R. J., 1983, Late Miocene and early Pliocene basaltic rocks and their implications for crustal structure, Northeastern California and South-central Oregon: Geological Society of America Bulletin, v. 94, p. 292-304.

Nebert, D. D., 1985, Development and application of a water-budget model for lake-level fluctuation, Goose Lake basin, Oregon-California: Masters Thesis, Portland State University, Portland, Oregon, 119 p.

Oregon Department of Water Resources, 1980, Land use: Goose and Summer Lake drainage basin, scale $1: 317,000$.

Peterson, N. V., February 1959, Preliminary geology of the Lakeview uranium area, Oregon, The Ore Bin, v. 21, no. 2, p. 11-20.

Peterson, N. V., Brown, D. E., and McLean, G. D., 1980, Preliminary geology and geothermal resource potential of the Lakeview area, Oregon: State of Oregon Department of Geology and Mineral Industries Open-File Report 0-80-9, pl. 1, scale 1:62,500, pl. 2, scale 1:62,500, 108 p.

Peterson, N. V., and McIntyre, J. R., 1970, The reconnaissance geology and mineral resources of Eastern Klamath County and Western Lake County, Oregon: State of Oregon Department of Geology and Mineral Industries, Bulletin 66, $70 \mathrm{p}$.

Phillips, K. N., and Van Denburgh, A. S., 1971, Hydrology and geochemistry of Abert, Summer, and Goose Lakes, and other closed-basin lakes in south-central Oregon: U.S. Geological Survey Professional Paper 502-B, $86 \mathrm{p}$.

Redmond, Kelly T., 1985, An inventory of climate data for the State of Oregon: Office of the State Climatologist, Climatic Research Institute, Oregon State University, Corvallis, Oregon, Report SCP3.

Robinson, T. W., 1958, Phreatophytes: U.S. Geological Survey Water-Supply Paper 1423, 85 p.

Sammel, E. A., and Craig, R. W., 1981, The geothermal hydrology of Warner Valley, Oregon: A reconnaissance study: U.S. Geological Survey Professional Paper 1044-I, 147 p.

Saxton, K. E., Johnson, H. P., and Show, R. H., 1974, Modeling evapotranspiration and soil moisture: Transactions of the American Society of Agricultural Engineers, v. 17, n. 4, p. 673-677.

Smith, R. E., and Williams, J. R., 1980, Simulation of surface-water hydrology, in Knisel, W. G., ed., GREAMS: U.S. Department of Agriculture, Construction Report No. 26, 643 p.

Trauger, F. D., 1951, Basic ground-water data in Lake County, Oregon: U.S. Geological Survey Open-File Report, pl. 2, 1:125,000.

U.S. Department of Agriculture, 1978, USDA report on water and related land resources, Goose Lake Drainage Basin, Oregon: U.S. Department of Agriculture in cooperation with Oregon State Department of Water Resources, $96 \mathrm{p}$. 
U.S. Department of Agriculture, Soil Conservation Service, 1980, Soil survey of Modoc County, California, Alturas area: U.S. Department of Agriculture, Soil Conservation Service, 154 p.

U.S. Department of Energy, 1985, Processing site characterization report for the uranium mill tailings site at Lakeview, Oregon: Uranium Mill Tailings Remedial Action Project, UMTRA-DOE/AL-050106.0000, 272 p., 1 appendix.

U.S. Geological Survey, 1980a, Land use and land cover, 1974-79, Klamath Falls, Oregon-California: U.S. Geological Survey Land-Use Surveys Open File 80-858-a, 1:250,000.

U.S. Geological Survey, 1980b, Land use and land cover, 1974-79, Alturas, California-Oregon: U.S. Geological Survey Land-Use Surveys Open File 80-153-1, scale 1-250,000.

Vorhis, R. C., 1979, Transmissivity from well data: National Water Well Association, Well Log, v. 10, n. 11, p. 50-52.

Walker, G. W., 1963, Reconnaissance geologic map of the eastern half of the Klamath Falls (AMS) quadrangle, Lake and Klamath Counties, Oregon: U.S. Geological Survey Mineral-Investigations Field Studies Map MF-260, scale 1:250,000.

Waring, G. A., 1908, Geology and water resources of a portion of South-Central Oregon: U.S. Geological Survey Water-Supply Paper 220,86 p.

Weiss, J. S., and Williamson, A. K., 1985, Subdivision of thick sedimentary units into layers for simulation of ground-water flow: Ground Water, Journal of National Water Well Association, v. 23, n. 6, p. 767774.

White, J. R., and Neff, E. L., 1983, Soil-vegetation-hydrology studies Volume II, A user manual for ERHYM: U.S. Department of Agriculture, A.R.S., Agricultural Research Results, ARR-W-29, January, 1983, 38 p.

Wolff, R. G., 1982, Physical properties of rocks--Porosity, permeability, distribution coefficients, and dispersivity: U.S. Geological Survey Open-File Report 82-166, 118 p. 


\section{APPENDIX I--TECHNICAL ASPECTS OF THE APPLICATION OF A DEEP PERCOLATION MODEL FOR ESTIMATING GROUND-WATER RECHARGE}

The following discussions summarize the methods and data used to estimate recharge to the Goose Lake basin by deep percolation of precipitation and irrigation water.

\section{Method}

The quantity of recharge that occurs in the basin from direct infiltration of precipitation and irrigation water was estimated using moisture and energy-balance methods. The moisture and energy-balance equations used are solved on a daily basis for discrete subareas of the basin, using a computer program, or model, known as the Deep Percolation Model for estimating Ground-water Recharge--"DPM-GWR" (Bauer and Vaccaro, 1987). The following processes are included in the model to account for transferance of moisture and energy between the root zone and the atmosphere: soil moisture accumulation; evaporation from bare soil; plant transpiration; surface-water runoff; accumulation, melting, and sublimation of snow; and accumulation and evaporation of intercepted precipitation (fig. A-1).

Deep percolation of precipitation and irrigation water is solved for as the residual, $\mathrm{R}$, in equation 1 :

$$
R=P+I-R O-E_{S}-T-E_{i}-\Delta S M-\Delta S P
$$

$$
\begin{array}{ll}
\text { where } \mathrm{P} & =\text { precipitation, } \\
\mathrm{I} & =\text { applied irrigation water, } \\
\mathrm{RO} & =\text { runoff, } \\
\mathrm{E}_{\mathrm{S}} & =\text { evaporation from bare soil, } \\
\mathrm{T} & =\text { plant transpiration, } \\
\mathrm{E}_{\mathrm{i}} & =\text { evaporation of intercepted moisture, } \\
\Delta \mathrm{SM} & =\text { change in soil moisture, and } \\
\Delta \mathrm{SP} & =\text { change in snowpack. }
\end{array}
$$

Equation 1 is solved on a daily basis for subareas of the modeled region, which are assumed to be homogeneous with respect to soils, slope, altitude, vegetation, and other parameters which affect recharge. The Goose Lake basin was divided into a regular array of 1,239 equal-sized, rectangular subareas or cells. One hundred seventy cells representing areas covered by water bodies were excluded from the model, leaving a total of 1,069 active cells where recharge estimates were made. Each cell had dimensions of 5,000 feet by 5,000 feet, and the $y$-axis of the array was oriented in a north-south direction (fig. 11 of this report).

Daily maximum and minimum temperatures and precipitation data from weather sites are intepolated to each cell. Interpolated temperatures are adjusted for altitude using lapse-rates and are weighted according to distances from weather stations. Interpolated daily precipitation totals are also weighted by a function of distance from weather stations. If average annual precipitation at a cell is known, daily precipitation at that cell is estimated using the ratios of daily to annual precipitation at weather stations. Irrigation rates (specified by the user) are added to daily precipitation at cells where irrigated crops occur. Potential evapotranspiration (PET), the evapotranspiration that would occur for a fully grown, fully covered field of alfalfa, water nonlimiting, can be calculated at all cells where altitude is specified. If land slope and aspect are also specified, PET calculations are corrected for the amount of incident solar radiation. The form of precipitation (rain or snow) is determined based on air temperature (above or below $32 \mathrm{oF}$ ). If precipitation occurs as snow, the depth of the snowpack is increased by the amount of precipitation. Sublimation of the snowpack is computed using user-specified rates. If precipitation is rain, an amount is intercepted, dependent on the amount and type of foliage and leaf litter. Interception storage is allowed to evaporate at the potential rate. Moisture that reaches the soil surface (rainfall plus snowmelt minus interception--hereafter referred to as "incident moisture") partly infiltrates and partly runs off as surface water. 


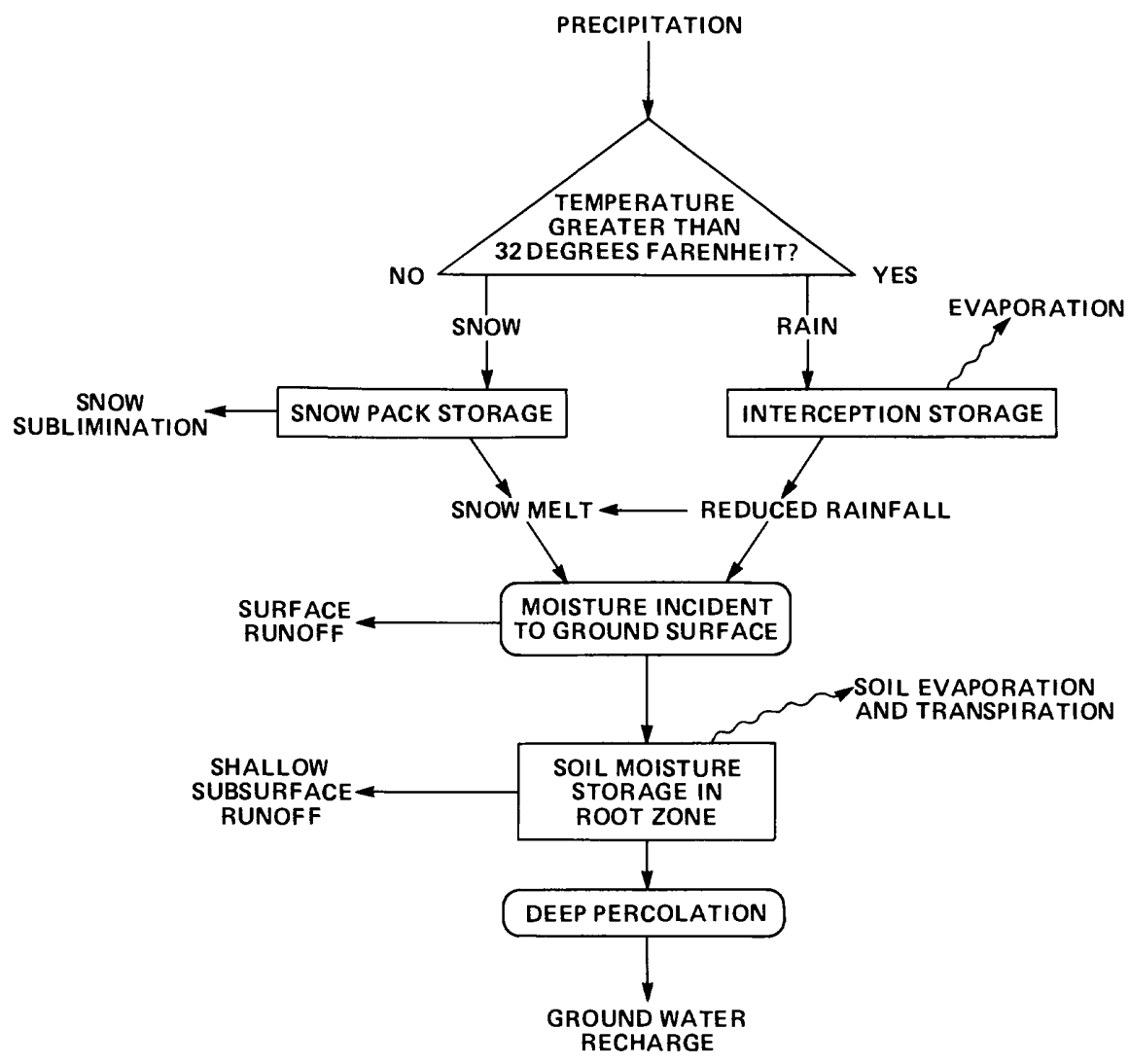

Figure A-1.--Processes included in the computation of recharge using the hydrologic mass-balance model.

The surface runoff for each cell is computed on the basis of the modified SCS (Soil Conservation Service) method of Wight and Neff (1983). This method is based on the SCS curve-number technique for determining surface runoff from small watersheds. When measured stream-discharge data are used with the model, runoff values computed for each block using the modified SCS method are used to apportion the measured streamflow (minus the base flow) to the cells of the model.

After reductions by interception and runoff, any surplus moisture from precipitation and snowmelt is assumed to infiltrate the soil, where it is added to soil-moisture storage in the root zone. When available moisture exceeds the storage capacity of the soil, the surplus is assumed to be deep percolation.

Potential soil evaporation, $\mathrm{PE}_{\mathrm{s}}$, is computed by subtracting the evaporated intercept moisture from $P E T$ and multiplying by the fractional amount of land not covered by foliage. Actual soil evaporation, $E_{5}$, is estimated from the relation presented in Saxton and others (1974) and occurs only from the top 12 inches. The difference between PET and $\mathrm{PE}_{\mathrm{S}}$ goes to potential plant transpiration, PT. Moisture will not be evaporated at the potential rate if soil-moisture contents are below field capacity. Unused energy is partly reflected back to the foliar cover, where it contributes to PT. PT is also dependent upon plant type and stage of growth. Finally, PT is multiplied by the appropriate crop-growth coefficient (Bauer and Vaccaro, 1987) to give the potential transpiration for the particular vegetation specified for the cell.

The amount of transpiration from each soil layer is based on root depth and density, soil type, and the ratios of (1) actual to potential plant transpiration and (2) available to maximum soil moisture content. The assumed distribution of root density is based on a linear relation between root mass and soil depth.

The major processes simulated by the model are described in additional detail by Bauer and Vaccaro (1987). The following section describes the data that were available to support this application of the model in the Goose Lake basin. 


\section{Data Requirements}

Use of the model requires regionalized data describing the physical characteristics of the basin. These include (1) depth, texture, and water-holding capacity of soil associations; (2) mean root depth, interception capacity, and percent foliar cover for each vegetation type; and (3) land-surface altitude. Basic climatic data requirements include (1) daily maximum and minimum temperatures and precipitation at local weather stations and (2) average July minimum and maximum temperatures. Optional weather data used in this application of the model were mean monthly lapse rates ${ }^{2}$ of minimum and maximum temperatures and average annual precipitation for each cell in the basin. Other data used in this analysis included (1) sublimation and minimum potential evapotranspiration rates, (2) daily streamflow to Goose Lake, and (3) mean monthly baseflow.

Twenty-two soil groups were defined, based on generalized soil maps of the Oregon side of the basin from U.S. Department of Agriculture (1978), detailed (1:24,000 scale) mapping of privately owned lands in California from U.S. Department of Agriculture (1980), and unpublished soil maps of the Modoc National Forest (Kenneth Luckow, Soil Scientist, U.S. Forest Service, Alturas, California, written commun., 1986). Each of these soil mapping projects had used different mapping units and had mapped at different scales. The map units used in California were correlated with units used in Oregon according to depth, water-holding capacity, and texture. The average properties of each soil group are listed in table A-1.

Landcover and vegetation distributions were derived from U.S. Geological Survey land-use and landcover maps for the Klamath Falls and Alturas Quadrangles (U.S. Geological Survey, 1980a and 1980b). These maps were supplemented with OWRD land-use mapping of irrigated agriculture (Oregon Water Resources Department, 1980). A land-use category of forest, sage, grass, bare soil, open water, or alfalfa was specified for each model cell. Maximum root depth, interception capacity, and percent foliar cover for the principal landcovers in the basin are given in table A-2. Within any cell, the landcover is a mixture of many vegetations; for example, bitterbrush and sage commonly occur together in the low hills bounding the valley floor and usually have an understory of grasses. Thus each landcover category is a generic term for a mixture of vegetations in which the name of the category reflects the dominant vegetation.

Average altitude within each cell, used to calculate temperature and PET, was estimated from digital elevation data for the basin.

Daily climatic input to the model consisted of minimum and maximum temperature and daily precipitation data from the weather stations at Lakeview (elevation 4,780 feet) and the Round Grove Ranger Station (elevation 4,890 feet). These stations were selected because of their excellent long-term records. Although located outside the drainage basin, Round Grove was selected due to its higher elevation and proximity to higher-elevation areas of the basin, where the micro-climate probably differs from that of Lakeview. This consideration is important when using the DPM-GWR because temperature and precipitation data at each cell are estimated by interpolation from weather stations. Estimates of daily temperature at cells distant from weather stations are improved if temperature-lapse rates are known. Estimates of monthly lapse rates by Bauer and Vaccaro (1987) for southeastern Washington were used in this study.

Average annual precipitation at each cell was used to estimate daily precipitation at the cell (as described in the previous section). Average annual precipitation was obtained from the isohyetal map shown in figure 4 of this report.

\footnotetext{
2 Temperature change in degrees per unit change in altitude.
} 
Table A-1.--Average values of soil thickness, water-holding capacity, and texture used to estimate deep percolation of precipitation and irrigation water

\begin{tabular}{|c|c|c|c|c|c|}
\hline $\begin{array}{l}\text { Soil } \\
\text { group } 1 \\
\text { no. }\end{array}$ & $\begin{array}{l}\text { Map- } \\
\text { unit }{ }^{2} \\
\text { no. }\end{array}$ & $\begin{array}{l}\text { Principal } \\
\text { associations }\end{array}$ & $\begin{array}{l}\text { Average } \\
\text { depth } \\
\text { (inches) }\end{array}$ & $\begin{array}{l}\text { Average } \\
\text { water- } \\
\text { holding } \\
\text { capacity } \\
\text { (inches } \\
\text { per } \\
\text { 6-inch } \\
\text { interval) }\end{array}$ & Texture $^{3}$ \\
\hline 1 & 1 & Calder-Pit & 60 & 1.2 & 2.5 \\
\hline 2 & $*$ & Gwin-Anatone-Smarts & 15 & 0.5 & 2.8 \\
\hline 3 & * & Puls-Lawyer-Pass Canyon & 20 & .6 & 2.7 \\
\hline 4 & 4 & Lakeview-Goose Lake-Ozamis & 60 & 1.1 & 2.1 \\
\hline 5 & 5 & Sherrard-Stearns & 18 & 1.2 & 1.6 \\
\hline 6 & 6 & Tandy-Ozamis & 60 & 1.0 & 1.4 \\
\hline 7 & $*$ & Behanin-Keating-Bieber & 23 & .6 & 2.3 \\
\hline 8 & 8 & Paulina-Chinchelo & 40 & 1.2 & 2.2 \\
\hline 9 & 9 & Bieber-Salisbury & 23 & .8 & 2.0 \\
\hline 10 & 10 & Drews (level) & 60 & 1.0 & 1.7 \\
\hline 11 & 11 & Drews (slopes) & 60 & 1.0 & 1.7 \\
\hline 12 & $*$ & Lamondi-Loberg & 50 & .7 & 2.0 \\
\hline 13 & $*$ & Smarts-Wapal-Gralic & 40 & .7 & 1.8 \\
\hline 14 & $*$ & Aikman-Patio-Lawyer & 50 & .8 & 2.4 \\
\hline 15 & 15 & Lobert & 60 & 1.0 & 2.0 \\
\hline 16 & $*$ & Demasters-Smarts & 50 & .9 & 2.6 \\
\hline 17 & Not used & -- & -- & -- & -- \\
\hline 18 & 18 & Puls-Pauley & 28 & 1.0 & 2.1 \\
\hline 19 & Not used & -- & -- & -- & -- \\
\hline 20 & 20 & Lorella-Bluejoint-Booth & 24 & .8 & 1.1 \\
\hline 21 & 28 & Rockland & 0 & 0.0 & 3.0 \\
\hline 22 & 22 & Hopgood-Hartis & 60 & .5 & 1.1 \\
\hline 23 & 23 & Booth-Bluejoint & 29 & .8 & 1.1 \\
\hline 24 & 26 & Woodcock-Mound & 46 & .3 & 1.0 \\
\hline
\end{tabular}

1Up to 24 soil groups may be designated within the DPM-GWR. The number shown was used to identify each group within the input to DPM-GWR.

2Map unit numbers correspond with unit numbers used by (U.S. Department of Agriculture (1978, p. 13). Soil groups denoted by an asterisk $\left(^{*}\right)$ are aggregates of soil associations mapped by the U.S. Forest Service (Kenneth Luckow, Soil Scientist, U.S. Forest Service, Alturas, California, written commun., 1986).

${ }^{3}$ Key to textures: 1.0 , sand; $1.1-1.9$, sandy loam; 2.0 , loam; $2.1-2.9$, clay loam; 3.0 , clay. 
Table A-2.--Maximum values for root depth, percent foliar cover, and interception capacity for landcovers in Goose Lake basin

\begin{tabular}{lccc} 
Landcover & $\begin{array}{l}\text { Maximum root } \\
\text { depth (feet) }\end{array}$ & $\begin{array}{l}\text { Maximum } \\
\text { percent } \\
\text { foliar cover }\end{array}$ & $\begin{array}{l}\text { Maximum } \\
\text { interception } \\
\text { capacity (in) }{ }^{1}\end{array}$ \\
\hline Forest & 33.0 & 80 & 0.4 \\
Grass & 22.0 & 100 & 0.06 \\
Sage & 34.6 & 35 & 0.06 \\
Alfalfa & 25.0 & 100 & 0.11 \\
\hline
\end{tabular}

1Bauer and Vaccaro, (1987).

2William Schrader, U.S. Department of Agriculture, Soil Conservation Service, Lakeview, Oregon, August 1986.

3David Wenzel, Soil Scientist, U.S. Forest Service, Lakeview, Oregon, August 1986.

Observed daily values of streamflow are optional but recommended input to the model. As previously described, if observed data are not available, the DPM-GWR computes runoff by the U.S. Soil Conservation Service curve-number method. When observed streamflow data are used, as they were in this study, the curvenumber method is used to compute apportionment factors for distributing the runoff among model cells.

Daily basin-wide streamflow was synthesized for the period 1954-80 using measured streamflow on Cottonwood Creek near Lakeview as an index to basin-wide streamflow. Cottonwood Creek was selected as the index because of its long, good-quality record during the period of interest. It is also less affected by upstream diversions and reservoir regulation than Drews Creek, the only other stream in the basin with longterm discharge data available.

Cottonwood Creek drains only 39 square miles (4 percent) of the Goose Lake basin; however, Nebert $(1985$, p. 19) shows a strong correlation (0.96) between subbasin drainage area and mean annual stream discharge within the basin. It was recognized that for shorter time intervals the flow in Cottonwood Creek would be less representative of streamflow in other subbasins due to differences in geology, topography, aspect, and precipitation. Streamflow data for two streams outside the Goose Lake basin were incorporated in the synthesis of basin-wide streamflow to account for some of the effects of subbasin variation on local streamflow. Data used were for the Chewaucan River at Paisley, Oregon, and Deep Creek near Adel, Oregon.

The method used to synthesize daily basin-wide streamflow was as follows:

(1) Monthly streamflows in Cottonwood Creek, Deep Creek, and the Chewaucan River were computed.

(2) Streamflow in Cottonwood Creek was adjusted for upstream storage in Cottonwood Reservoir.

(3) A basin factor was computed equal to the ratio of mean annual streamflow to Goose Lake (Nebert, 1985) to mean annual streamflow in Cottonwood Creek near Lakeview, for the period 1946-75. 
(4) Monthly streamflow to Goose Lake was computed as the product of monthly streamflow in Cottonwood Creek and the basin factor.

(5) Ratios of daily to monthly discharge were computed for Cottonwood Creek, Deep Creek, and the Chewaucan River.

(6) The three ratios were averaged to give a composite ratio for each day.

(7) A long-term average of the composite ratios was computed for each day of the year for the 1954-80 period.

(8) Daily streamflow to Goose Lake was computed as the product of the average composite ratio for that day and the monthly streamflow to Goose Lake.

Nebert (1985, p. 46) estimated mean annual surface-water inflow to Goose Lake to be 210,000 acre$\mathrm{ft} /$ year (1946-75). Nebert's estimate was based on long-term records of flow in Cottonwood Creek near Lakeview and short-term or reconstructed records for 10 other streams in Oregon and California. His estimate agrees well with those of Daum (1966; 204,000 acre-ft/yr, 1919-54), Jacobs (1909; 281,000 acre$\mathrm{ft} / \mathrm{yr})$, and Phillips and Van Denburgh $(1971 ; 250,000 \mathrm{acre}-\mathrm{ft} / \mathrm{yr})$. The mean annual discharge of Cottonwood Creek for the period 1946-75 was 17,100 acre-ft/yr. The basin factor used to adjust the monthly streamflow in Cottonwood Creek for the area of the basin was:

$$
\frac{210,000 \text { acre-ft/year }}{17,100 \text { acre-ft } / \mathrm{yr}}=12.28
$$

Daily variations in streamflow within the basin due to subbasin characteristics were addressed as well as possible by using daily-to-monthly discharge ratios for Deep Creek and the Chewaucan River to compute the daily composite ratios of daily-to-monthly discharge for the basin. Averaging this composite ratio for each day over the period of record gave each month a characteristic hydrograph reflecting historical daily streamflow patterns. This served to dampen the effect of variations in daily discharges between the three streams from year to year.

The average annual surface-water inflow to Goose Lake (assuming no irrigation diversions) calculated by these methods for the period 1954-1980 was 196,000 acre-ft/yr. The computed annual streamflow to Goose Lake for water years 1954-1980 is shown in figure A-2.

The ground-water component of basin streamflow (baseflow) is deducted from daily streamflow in DPM-GWR using user-supplied estimates of monthly baseflow for each year. It was considered impractical, if not impossible, to estimate the basin-wide ground-water component of streamflow using conventional methods; however, an estimate of the baseflow contribution was made by taking the mean of minimum monthly basin streamflow. Thus, the lowest daily flows for each month of the 1954-1980 period were averages by month to approximate the mean monthly baseflow. Mean monthly minimum flows would be greater than actual baseflow during winter and spring months when heavy precipitation and (or) snowmelt contribute to the low-flow discharge. Mean annual baseflow, estimated in this way, is approximately $100,000 \mathrm{acre}-\mathrm{ft} / \mathrm{yr}$, or slightly more than half of mean annual streamflow. The mean monthly minimum basin streamflow from 1954 to 1981 is shown with the mean, maximum, and minimum monthly streamflow for the same period in figure A-3.

Irrigation water diverted from streams or pumped from wells is a potential source of recharge to the ground-water system if applied in excess of crop-consumptive use requirements. Irrigation practices in Goose Lake basin are typically inefficient, with large tracts still irrigated by flooding. The quantity of recharge available from this source was estimated by specifying average annual irrigation application rates at cells where irrigation occurs. 
Average annual diversion of streamflow for irrigation was estimated at 130,000 acre-ft/yr, based on 43,000 acres of irrigated land, an average crop-consumptive use requirement of $1.5 \mathrm{ft} / \mathrm{yr}$, and an average irrigation efficiency of 50 percent. Irrigation efficiencies in the basin range from approximately 30 to 40 percent for flood-irrigation systems to 60 to 80 percent for sprinkler systems (William Schrader, U.S. Soil Conservation Service, Lakeview, Oregon, written commun., January 1986). The exact proportion of use of these two basic systems in the basin is unknown, but the average irrigation efficiency for the basin probably lies between 40 and 60 percent. Eleven thousand acres of irrigated land lie in the California portion of the basin; the remainder lie in Oregon. The areal distribution of irrigation was derived from the map of irrigated acreage shown on plate $1 \mathrm{~b}$ of this report.

Irrigation from ground-water sources was considered separately because recharge estimates were needed for both pre- and post-ground-water development periods used in the ground-water flow-model analysis. Ground-water rights are held for approximately 7,000 acres on the Oregon side of the basin; however, for half this acreage the rights are supplemental to surface-water supplies. If an application rate of 3 acre- $\mathrm{ft} / \mathrm{acre}$ is assumed for the acreage where ground water is the primary source (3,500 acres) and an application rate of 1.5 acre-ft/acre is assumed for the acreage where ground water is used to supplement, total irrigation from ground-water sources averages 16,000 acre-ft/yr in Oregon. In California, 10,000 acre-ft/yr of ground water were used in 1981 to irrigate 3,500 acres (Califormia Department of Water Resources, 1982, p. 25).

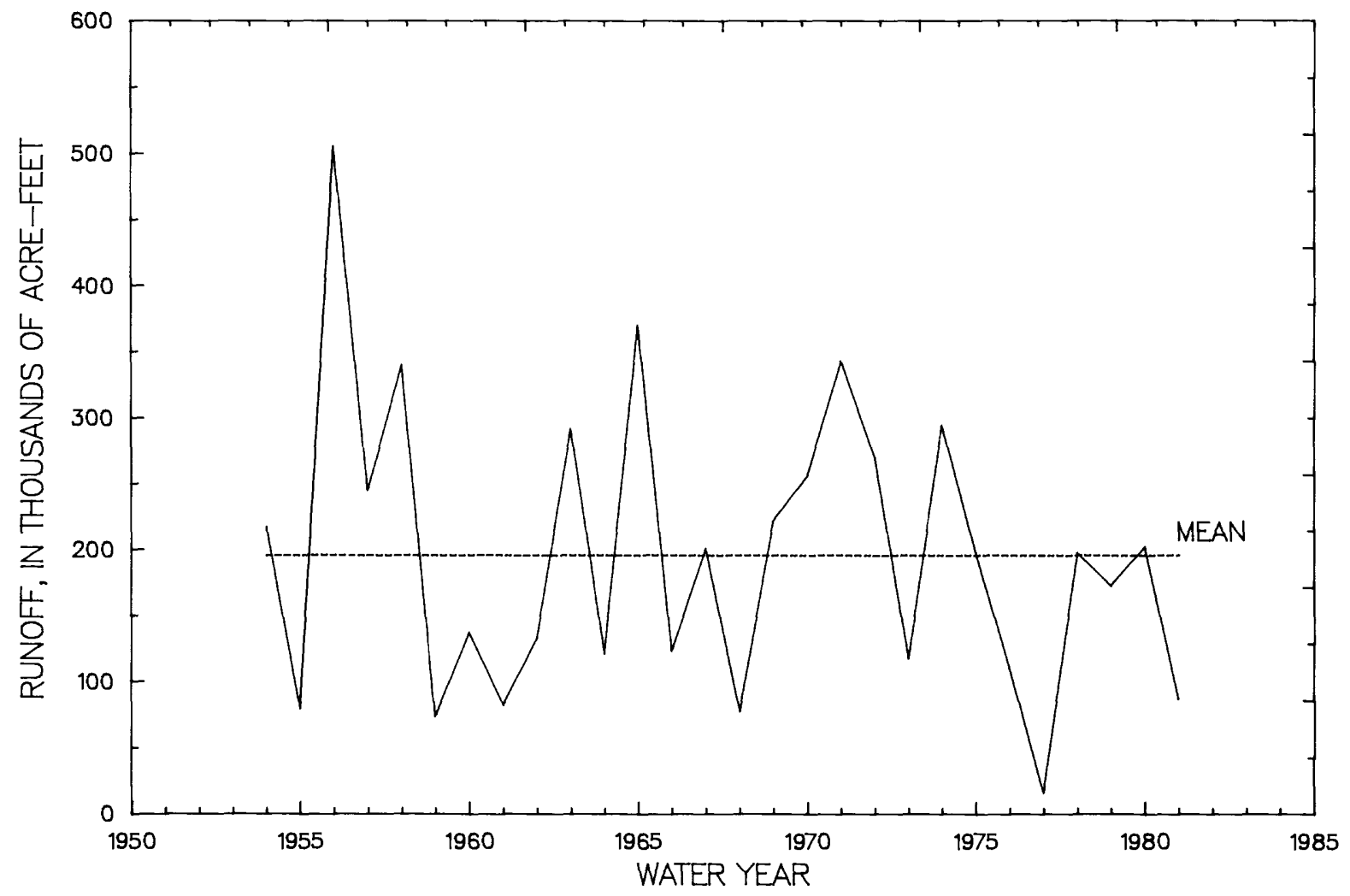

Figure A-2.--Estimated annual basin-wide streamflow, 1954-1981. 


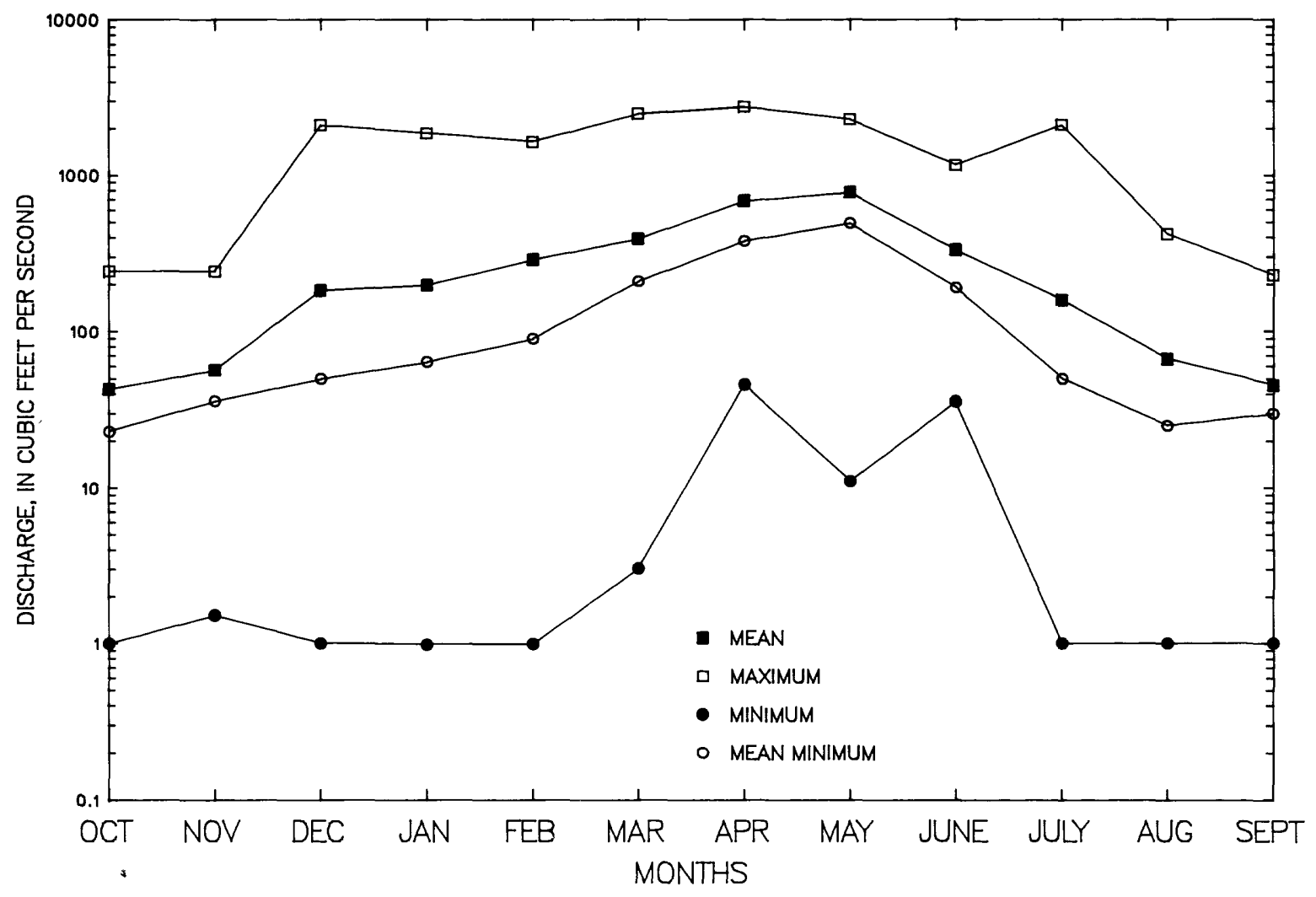

Figure A-3.--Mean, maximum, minimum, and mean minimum monthly basin wide-streamflow, 1954-1981. 